Portland State University

PDXScholar

Dissertations and Theses

Dissertations and Theses

$5-25-1977$

\title{
The Influence of Ben Jonson on the Poetry of Yeats
}

Wayne Kenneth Chapman

Portland State University

Follow this and additional works at: https://pdxscholar.library.pdx.edu/open_access_etds

Part of the English Language and Literature Commons Let us know how access to this document benefits you.

Recommended Citation

Chapman, Wayne Kenneth, "The Influence of Ben Jonson on the Poetry of Yeats" (1977). Dissertations and Theses. Paper 2613.

https://doi.org/10.15760/etd.2609

This Thesis is brought to you for free and open access. It has been accepted for inclusion in Dissertations and Theses by an authorized administrator of PDXScholar. Please contact us if we can make this document more accessible: pdxscholar@pdx.edu. 
AN ABSTRACT OF THE THESIS OF Wayne Kenneth Chapmen for the Mester of Arts in English presented May 25, 1977.

Title: The Influence of Ben Jonson on the Poetry of Yeats

APPROVED BY MEMBERS OF THE THESIS COMMITTEE:

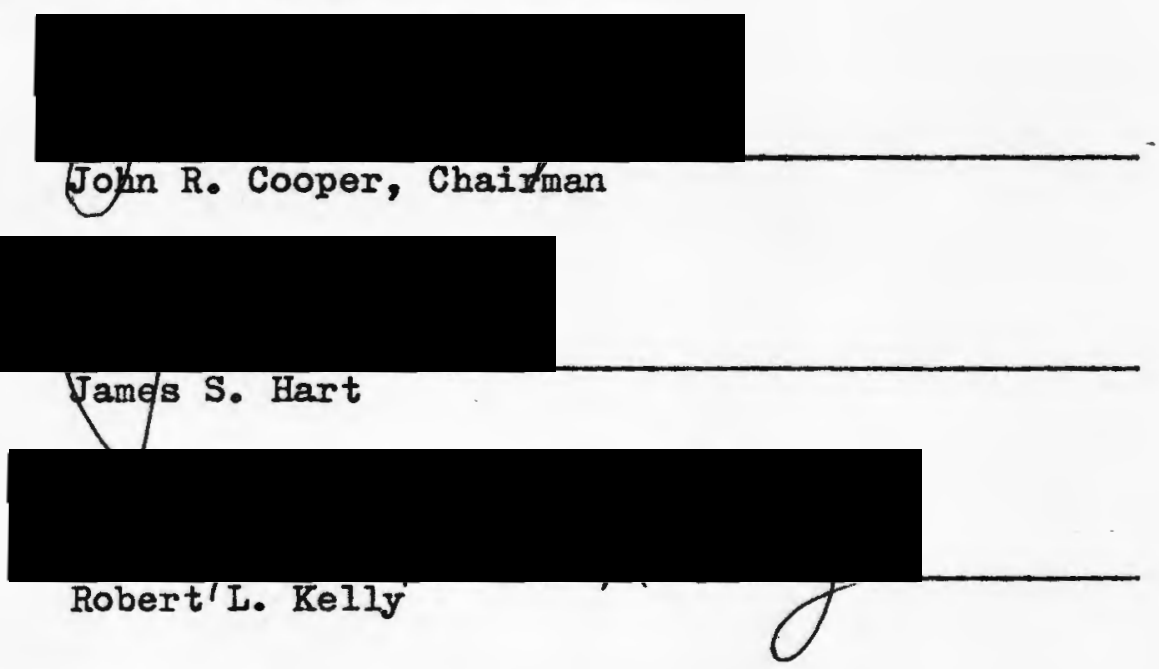

What this thesis attempts to do is to render as full a picture as possible of Yeats's interest in Ben Jonson, using to the fullest advantage the many hints that come from Yeats and secondary criticism. Specifically, the focus of this paper is on the process by which Yeats was able, like Eliot, Pound and others, to found a tough, new poetic style with reference to this seventeenth-century period of Jonson. Yeats's reading of "Jonson and the others," which took place at the turn of this century, triggered a whole series of discoveries by Yeats which anticipated the aesthetic beliefs of his 
famous friends in the modern movement, whose later influence upon his poetry generally fortified poetic principles which had already found their way into his work. Eis early plays for the Abbey Theatre, for instance, demonstrate his call for a return to the "roota" of poctic power that Synge associated with the best plays of Jonson and Moliere, and his poetry of that period demonstrates his first attempt at finding the "passionate syntax" of Jonson, Donne, Shakespeare and others. But before turning to the subject of Yeats's poetry and his interest in Jonson as an accessory to the change of poetic style that took place, it must be conceded that Yeats and Jonson worked from essentially opposite points of view-as opposite as are their respective romantic and classical modes. Therefore the first chapter is devoted to the critioal problem of demonstrating Yeats's accommodation of Jonson despite the difference between their approaches, an accommodation that was achieved by Yoats's unorthodox interpretation of Jonson as a romantio or deliberate writer of Imagination.

Wext, the second chapter demonstrates how Yeats's early drama gives voice to the poetios which were at the same time transforming his verse. The portrayal of artist and art in relation to contrasting elements of society (king, "citi-sins" and beggar-man) in the early Abbey plays illustrates Yeats's increasing use of Jonson's arguments in defense of aristocratic values at oourt, and the second chepter recognizes in the plays of Yeats a oritical defense of poetry which both elaborates the findings of the first chapter and anticipates the third, which is the chapter devoted to the poetry. Yeats's use of characters in poetic drama is shown to be related to Jonson's 
theory of humors, a use of dramatic character that helped Yeats to modernize his verse by creating masks or personae which represent, as in Eliot's poetry, the "disembodied consciousness" of the poet. Finally, the third chapter illustrates not only Jonsonian mam terial, form, and language to be found in the poetry that Yeate wrote after the profound change of style had taken place, but also the profourd change of vision that had accompanied it. Caught between the dream of Innisfree and the vision of apocalypse, Yeats vacillated between two Jonsons, the Jonson of the verse-epistle and the versemasque, on the one hand, and the Jonson of the humors comedy and the anti-masque, on the other. In Yeats's poetry, the opposition to one another of the two Jonsons is apparent when the custom, ceremony and "radical innocence" seen in "A Prayer for my Daughter" are opposed to "the worat" who, like Volpone, are "full of passionate intensity" in "The Second Coming." The stylistic change in Yeats's poetry is made modern by the personae who stand inside the poems and speak with the "passionate syntax" of an active man's speech, but the modern voice of Yeats is not heard until the poet steps from the Pre-Raphaelite dream into the world of actuality and action. Once there, the poet suffers the indignity of having to deal with the mob. But it is his aristocratic and heroic temperament that urges him to the two types of expression that Yeats learned particularly from Jonson. Like Jonson, Yeats produced two very different types of poetry-one dedicated to his patrons, the nobility and the onlightened few who understood and appreciated his work; and the other directed at the "knaves" and "dolts" who belittled the value of the poet. 


\title{
THE INFLUENCE OF BEN JONSON ON THE \\ POETRY OF YEATS
}

\author{
by \\ WAYNE KGMNETH CHAPMAN
}

A thesis submitted in partial fulfillment of the requirements for the degree of

\author{
MASTER OF ARTS \\ in \\ ENGLISH
}

\section{Portland State University \\ 1977}


TO THE OFFICE OF GRADUATE STUDIES AND RESEARCH:

The members of the Committee approve the thesis of Wayne Kenneth Chapman presented May 25, 1977.

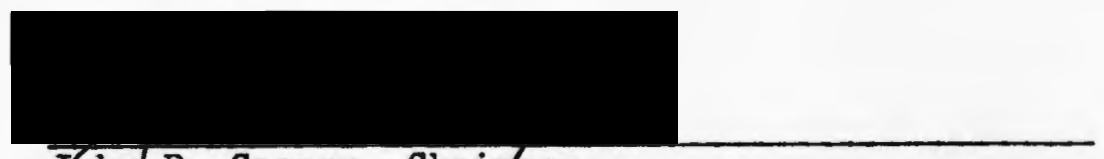
John R. Cooper, Chaiplman

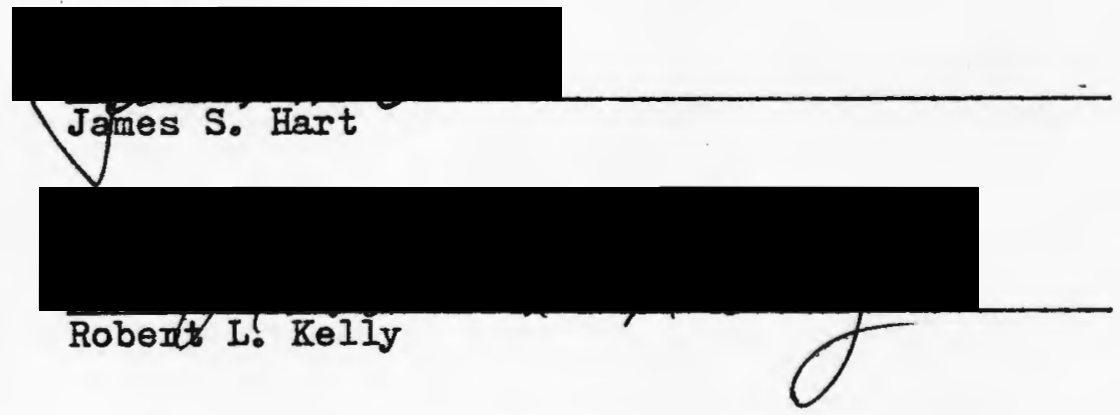

APPROVED:

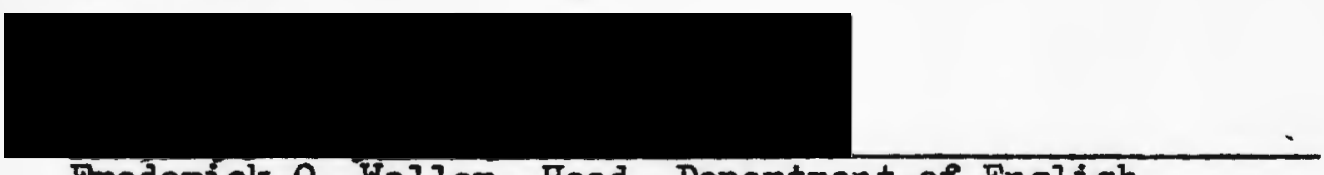

Frederick 0. Waller, Head, Department of English

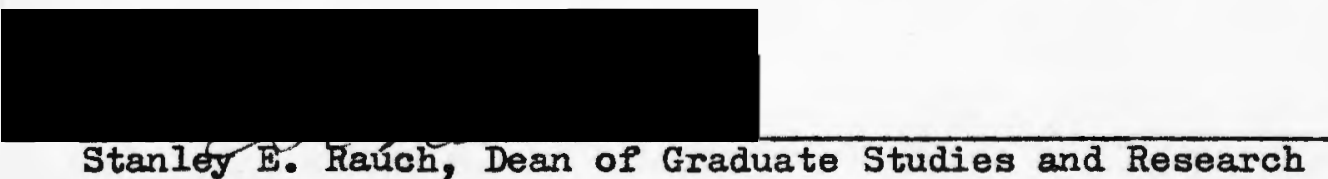




\section{ACRATOWLEDGEMENTS}

My hoarty thanks go to Professors James Hart, Robert Kelly and Asher Wilson for reading this thesis, for their suggestions, corrections and criticism. Furthermore, it is difficult to express the very deep appreciation that I feel for John Cooper's part in this paper. $\overline{H i s}$ patience and scholarly advice, as my advisor and chairman of the thesis committee, are enough in themselves to place him in the very highest regard. But he tried to teach me how to write. And that must have taken a great deal of courage in the beginning. Finally, my wife, Marilyn Manson, writing a thesis of her own in History, was tireless in her support of this effort of mine, and her enthusiasm and judgment are appreciated as much as she undoubtedly knows. For that rare, intense esprit de corps, I will perhaps yet regret having finished this project. 
TABIE OF CONTENTS

PAGS

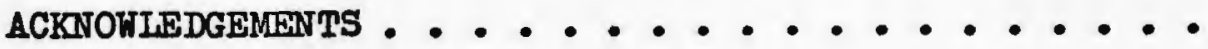

CEAPTIER

I YEATS AND JONSON: THE PROBLEY OF ASSOCIATION

Notes to Chapter I ..........

II THE PLAYS: AN APOLOGY FOR POETRY . . . .

Discoveries: Yeats and the Irish Players

Yeats and the Renaissance .......

The Island of Statues .........

The King's Threshold ..........

The Green Helmet ............

"An Aristocratic Form": Pound, the Moore Controverey, The Player Queen and "Plays for Dancers". .......

Notes to Chapter II . . . . . . . 95

III THE POEMS ................ 105

Tho Early Pooms ............ 111

In Transition the Emergence of the Hero

In the Seven Hoods ...........

The Green Helmet ..........

Responsibilities ............

Later Pooms the Occasional Form .... 
Summary and Conolustons .......

Hotes to Chaptor III ........

190

RFFEREATCES CITYSD 


\section{CHAPTER I}

\section{YEATS AND JONSON: THE PROBLEM OF ASSOCIATION}

It is regrettable that Yeats never got around to writing his article on Jonson, as he had considered doing after the appearance of his Spenser essay in 1906. ${ }^{1}$ If he had done so, the question of what Jonson meant to Yeats might have been much less difficult to answer. Yeats's interest in the work of Ben Jonson can still be sufficiently demonstrated, nevertheless, but, now, chiefly by means of the numerous and scattered traces of Jonson which appear throughout Yeats's published writings. Neither reference to the vast deluge of secondary criticism, nor the facility of obtaining all the important primary works in reprint, seems to help us very speedily to the easy answer we have been denied by circumstance, since it is the vastness, the extensiveness of this background into which these traces are projected, that imposes, perhaps unexpectedly, the first considerable impediment to this project. We begin to find evidence of an interest in Jonson in plaoes where we would not have thought to look. And we find it to be an interest throughout Yeats's entire literary career, from the earliest to the latest phases. This is a problem, of course, for, though we may be little surprised as admirers of the middle and late Yeats, we do not expect to discover an interest in Jonson earlier, say, than in the early Abbey plays-plays written in company and sometimes in collaboration with such practitioners of common speech and 
Irish 1diom as Douglas Hyde, Lady Gregory, George Moore, Edward Martyn, John Synge and, later, Sean O'Casey-or in the poems written at the same time. An awakening interest in Jonson, like that of a corresponding interest in Dean Swift and Walter Savage Landor, one most frequently associates with this later period, often called the "middle phase." The impression of personality brimming over itself with the richness of life that we have in Jonson, or more rightly, we have from the created persona of virtually any one of his poems, simply is not a part of the consistent dream-voice of Yeats's work up until this time. But "Style," as Yeats is eventually persuaded to believe, "personality-deliberately adopted and therefore a mask-is the only escape from the hot-faced bargatners and the money-changers. "2 Style and personality are equivalent. And the poetic persona of a poem like "September 1913," for instance, a poem of the middle phase which clearly represents the change in style by this time manifestly the standard, certainly seems to be under the spell of a typically Jacobean contempt for the appetites and deceitfulness of middlo-class capitalism (e.g., the city comedies of Jonson, Marston, Middleton and Massinger). And the impression is anything but dispersed by Ezra Pound's intrusion into the picture and his coaching from the side lines.

What need you, being come to sense, But fumble in a greasy till And add the halfpence to the pence And prayer to shivering prayer, until

You have dried the marrow from the bone? For men were born to pray and saves Romentic Ireland's dead and gone, It's with O'Iraxy in the grave.

$$
\text { ("September 1913," 11. 1-8) }{ }^{3}
$$


At this point, two things should be stressed. In the first place, there is the divergence from that style of the early Pre-Raphaelite Yeats which noticeably ocours between 1900 and about 1910 and which is the projection of some ner, underlying critical beliefs. The stylistic change is profound. Secondly, there is a presence of interest in the gregarious and sometimes egregious "Big fatt man, that spake in Fymont coinoidental with Yeats's first published work. If we are to believe that Jonson may have had a prominent place in Yeats's interest during and after Yeats's dramatic change in style, how do we deal with an interest in Jonson that grows from the beginning, when their respective styles, not to mention their personal1ties, are so different as to seem the very opposite of one another? It will, of course, be illustrated just how different they are from each other. Thereafter, however, the purpose of the chapter will always be to show how they might then be brought together. What this first chapter contends, therofore, and hopes to demonstrate is: that Yeats did make way for Jonson among his romantio onthusiasms, and that the change in style for whioh Jonson partly served as a model, though a change indeed dramatio and profound, was achieved by gradual steps that left the basio romantic perspeotive, though not. the substantive vision, of the early Yeats virtually unblemished. Still, it will be necessary to acknowledge-indeed to spell out-how different the two poets were in their attitudes to poetry. In Yeats, our expectations from having read those lush, of ten mystical poems that come out of the period of the Celtic MrilightThe Crossugys (1889), The Rose (1893) and Wind Among the Reeds (1899) 
-may lead us to be startled somewhat suddenly in the face of an anomalous figure like Jonson, a wolf among sheep. We oxpect, flrst of all, Blake, Shelley, Spenser, the Shakespeare of Richard II and Hamlet; then we expect to see shades and hear echoes of Nordsworth, Coleridge, Tennyson, Morris, Rossetti, Dowson, Johnson, Swinburne, Wilde and, boyond that, the troop of the ancients and the bardio logions of Romantic Ireland of the eighteenth and nineteenth centuries. 5 Acknowledging Yeats's oareful and studied babits of composition, wo begin to realize how consoiously our impression of the half-consolous and fantastically proportioned visionary design may have been arranged for us. The visual landscape for the reader must be no more indistinot than it is for the mood-creating melanoholy Poet who populates his poems with "Shadowy Horses," "pale dow," "shadowy pools," faded lovoliness, "dream-heavy hours," roses with countless impressions on roses, and, finally, the groat "groy twilight" itself. The poot is writing a certain kind of thing, with his mind quite made up about it. As rhythm is narrowly conceived by Yoats, it is the Poet's dovice "to prolong the moment of contemplation, the moment when we are both asleep and awake." 6 Giles Telfer, in "Yeats's Idea of the Gael," writes that Yoats's use of Gaelic folk myth and legend was "a personal and subjective uses he recreated it to express his dream" 7 but, beside the phantasmagoria of Yeats's oocultist beliefs, much of this material, though resembling the Pre-Raphaelite treatment of medieval material by Tennyson, Morris, Rossetti and others, was out of the main stream and, though fascinating in its own right, added to the poems a regrettable obsourity the weakness of which the notes, espe- 
cially of Hind Among the Reeds, tend to illuminate. We hardly think of Jonson so eagerly putting up a willowy veil of obscurity beside such an unfocused trail of images, In spite of his immense classical knowledge.

Similarly, the contrast between Jonson and the early Yeats cannot be made clearer than by depicting a perhaps equally superficialand popular-view of Jonson. Michael Jamieson sufficiently captures the spirit of it when he writes that Jonson

...was a bonhomous, oplnionated, and highly prized drinking companion in literary London, and the Hilliam Hickeys of this vorld might write him dom as an habitué of the Mermaid Tavern, the Sun, the Dog, the Mriple Tun, and the Apollo upstairs above the 0ld Devil. 8

The foous is on the man and not the work. So powerful has been the effect of the created personae of Jonson-to the suppression of the very literature they inhabit_that a collective and legendary personality should emerge that should be so satiafactory, so satiafying, that we shouldn't want to read the plays and poems themselves anymore. Yeats, in due course, was sufficiently attracted to the roluble personality aohieved by Jonson's style to have gone beyond the superficial view and actually read Jonson as "greatly" as his admiration for him prompted him to-though Jonson was still, on Mrs. Yeats's account, "not one of Yeats's gods." But this fact does nothing to dismiss the perplexity we must invite by standing these two poets and playwrights within the same visual frame and having them eaoh and simultaneously demonstrate that art which is, according to our aocustomed impression, individually and uniquely their om. 
For one thing, we can hardly imagine a more un-Jonsonian theater than the theater of Yeats. For Jonson, the art of play writing Is an art whioh makes lifelike oharaoters do and sey lifelike things for the purpose of social criticism. He mimios or imitates actuality while following a oonsolously wostern or classioal literary heritage. He is frequently oompared to Aristophanes, and his genius (though its restriction to oomedy has been questioned by Eliot) ${ }^{10}$ as well as his taste is for a satiric oomedy that instruots. 11 In Yeats, however, there is everywhere evidence of distruat of the material world in which mortal men, no less then wooden players on the "Daimon's" otring, improvise their parts according to "an inherited scenario."12 His theater, as we have grown to think of it, is Blakean in Inspiration, Easterm in reference, and not simply unrealistio in content, but otherworldly-and, at that, is indebted to a personal vision that is predominantly tregic. Blake, aside from Yeats's personal preference for tragedy, was an early and avid enthusiasm for Yeatss and it was to him that Yeats aocredited the idea that

the beautiful states of being which the artist in lifo or thought perceives by his imagination and tries to oall up in himself or others are the real and eternal world of which this vegetable universe is but a faint shadow. 13

Seen in this ray, Yeats and Jonson seem not only men of art with independent and differing attachments, but, in Yeats's om argot, they are "antithetioal." Jonson writes as a classicist, is tradi.tional in his method of "humourg" comedy: "Jonson studies manners, and retains throughout in his portrayel of the individual a strong social 
reference,"14 Yeats, on the other hand, writes as a romantic, is revolutionary in his "Plajs for Dancors," tragedies and tragi-comedies which, from Yeats's point of view, aro not so much adaptations from Japanese and Celtic traditions as they are a form of drama invented by Yeats himself, he insists upon elevating the poet not fust to a position of importance with reference to an elite patron class, but beyond to the statuary height of the romantio Poet-ag-Hero. In Yoats, as for the romantic, the imagination itself is given an elovated place over "olassical," objective judgment. The creative, not imitative, artist calls up for himself and his readers "the beautiful states of being" not entirely accessible to the ordinary person. And we are strongly indebted to him for such services first of all, because his access to the elevated Imagination, "Great Memory," Demogorgon or Daimon, provides a kind of holy link between humanity (the rest of us who are not Poets) and something greater than ourselves, something that motivates action in a dumb "vegetable universe"; and, secondly, because in Yeats the Poet supplies the raw stuff, in Images, neoessary to all of us in order to advance the soul one incarnation closer to the full realization of the "Inherited scenario." No more than this is probably necessary to establish a sense of perplexity at holding both great men thus upon a single stage and forcing them to pronounoe their differences. Their likenesses are much more interesting.

Until recontly, comparatively fow oritios and literary historians have made more than a passing note of Jonson's rather consplouous appearance in the poetry of Yoats. And especially in Yeats's criti- 
cal prose, where we also find an important element of the poet's dovelopment associated with Jonson, is this neglect apparent. Outside of Yeats himself, the leading offort of T. Mollindon, in the esser "Yeats and the English Renaissanoe" (1967), ${ }^{15}$ the oritical explorations of Donald Davie, in his essays "Miohael Robartes and the Danoor'" (1965) and "Yoats, The Master of a Trade" (1964), $8^{16}$ and the oontributing foous of perspective in Rupin Desai's published disserten tion, Yoats's Shakespeare (1971), 17 represent the important work of the few who do give the topio some attention. Since the deluge of Yeats criticism began to appear in the poet's om lifetime, few have proposed to address themselves to this subject, even to the degree of the restriotions imposed by design in the work of these three soholars. I probable reason for this is bound to be the incredible richness in Yeats, in art and in thought as represented in the essays. Perhaps symptomatic of this richness, Louls Macneice once complained that Yoats "sometimes makes a parade of leaming which he did not possess and sometimes he lays on proper names with a palette knife..."18 Regardless of the validity of the complaint, the profuse number of choices and directions of interest to the student of Yeats have always been a problem. But there is also a consistency, links and attachments that the poet-ossayist makes, when dealing with Jonson, that urges an end to the negleot of this particular interest of Yeats's, that makes Jonson a more noteworthy figure than others who, though having recelved more attention from critics, are by comparison short-lived as functionally valuable to the poetry. (Castiglione may be such a Pigure, who, appearing in the initial stages of the middle 
phase, has out-gloried in our critical attention the more obviously valuable examples of Shakespeare, Spenser and Jonson-Poets of the firat rank who are also professional men of letters.) $)^{19}$ As an interost which prompted in Yeats similarities of image, attitude and stylistic technique (personality; "Language most shews a mans speake that I may see thee"), ${ }^{20}$ Jonson's work has left its mark, not only on the landscape of many of Yeats's poems, but on the personee, the players who stend inside these poems and speak their lines. In the essays and correspondence of Yeats, the fragmentary notices of Jonson and his work seem to reflect, and at times anticipate, the transformation of Yeats's poetio style as it was gradually ocourring. It may therefore be possible to tell the story of this transformation from this particular new perspective. But these notices, being brief and broken off from larger contexts which suggest their particular value, must be fitted together like pieces of a rather scattered jigsaw puzzle. In all, there are some twenty-seven published traces of Jonson (in name) in Yeats's imsginative, oritioal and journalistio work. And obviously, it would be impractical to attempt the presentation of each of them in the present investigation. Therefore, as it is to be the purpose shortly to attempt a reconstruction of the Jonson Yeats saw and made use of in his criticism, It might be wise at this point to provide some instruction in advance of the labor, so that we might ease the labor by having something of the whole fitted together before we examine a select few of the principal parts. 
Yeats is not like Jonson, a classioist. This has been pointed out before. But Yeats can take to poets like Jonson and Donne, poets who can stand in Spenser's ohorus and oing in "brightnesse of braue and glorious words" beside romantics like Byron, Shelley, Tennyson and Morris. 21 But more than this: like the pursuit adrocated by Pound and Eliot, Yeats's reference to the seventeenth-century period of Jonson, in Yeats's studies of Shakespeare, Spenser, Jonson and his detractors, and, later, Donne, would greatly assist Yeats's transformation of style into that tough and simple representation of an active man's speech. And this is not to say that Yeats discovered what a Jacobean poet like Jonson could offer him stylistically on Jonson's terms (terms which were traditional and inherited from the ancients); rather, Yeats discovered ways of interpreting Jonson on Yeats's own romantic and revolutionary terms, to his own special purpose of creating a poetic alloy better suited to the harsh new age. Yeats believed that the prevaling modes of the practicing poet in both the seventeenth and nineteenth centuries were somehow to be reconciled into a modern mode. The classical poetic, the poetry of tradition, is the antithetical manner or "Magk" which must be co-ordinated (by "Creative Mind" and "Body of Fate") with the romantic Imagination or "Will" of the poet. He see, for instance, that this is the way Yeats works in "Ego Dominus Tuus," or at least, that this is his thought.

\footnotetext{
Hic.7.... you walk in the moon,

And, though you have passed the best of life, atill trace,

Enthralled by the unconquerable delusion,

Magical shapes.
} 
IIle.

By the help of an image

I oall to my own opposite, summon all

That I have handled least, least looked upon.

Hic. And I rould find myself and not an image.

IIle. That is our modern hope, and by its light

We have lit upon the gentle, sensitive mind

And lost the old nonchalanoe of the hand;

[Hic.7 A style is found by sedentary toll

And by the Imitation of great masters.

I call to the mysterious one who yot

Shall walk the wet sands by the odge of the stream

And look most like me, being indeed my double,

And prove of all imaginable things

The most unlike, boing my anti-self....

("Ego Dominus Tuus," 11. 4-14, 71-2, 76-80) 22

What results is a species of self-creating poets a poet who, contemplating self, invents instead the mask of self, which is its opposito; a poet who, by ohanges, is sad and gay, because of his uncertainty as to which (mask or solf) ho has discovered and which ho has lost. In fact, what we really have is a kind of solf-creating poetIy, a poetry in which the poet not only create a persona or mask for himself (or finds one), but a poetry in which the poet, in perfecting art, improves himself as he projects himself into different roles or incarnations belonging to the Great Wheel of history and oivilieations the poet moves oloser to the point at which knowledge and being of the eternal tragi-comio design of destinj are ono.

But how does this solve the special problem we have with those seferences to Jonson which indicate an aotive interest in the seventeenth-century poet before it had even oocurred to Yeats that a sty- 
listic change was necessary? If we look at Yeats's late comments conoerning the early influences on his first published work, The Island of Statues (1885), we discover something helpful. In 1937, Yeats was preparing for a complete edition of his work which was never produced for this proposed edition, he wrote "A General Introduotion for my Nork," in which the following account was given:

I was but eighteen or nineteen and had already, under the influence of The Feerie Oueene and The Sad Shepherd, written a pastoral play, and under that of Shelley's Prometheus Unbound two plays, one staged somewhere in the Caucasus, the other in a crater of the moon; and I knew myself to be vague and incoherent. 23

Only a year later, In "I Became an Author"-the text of a projected radio program appearing in The Iistener, 4 August 1938; his last work, aside from The Autobiographr, to be published in his lifetime - Yeats gave substantially the same account but with notable differences.

When eighteen or nineteen I wrote a pastoral play under the influenoe of Keats and Shelley, modified by that of Jonson's 'Sad Shepherd,' and one of my friends showed it to some Mrinity undergraduates who were publishing the Dublin University Review, an ambitious political and literary periodical that lasted for a few months...24

In the earlier account, Jonson and Spenser stand together (in one play) opposite Shelley (In tro plays), and in the final account, Jonson alone holds the ground as a modification of "the influence of Keats and Shelley" (In a single play together). The obvious solution to our problem with Jonson's presence in Yeats's earliest work, then, is that Yeats had been acutely seleotive in this choice from Jonson's 
pleys. That the Jonson play, it seems, is the most Spenserian of his works, may in fact support the contention that it was one of Yeats's genuine enthusiasmg-though the air of nonchalance in which the association is made may give us notice of the limitations we suspect in the comparison. In any case, if Jonson held an appeal for the eighteen- or nineteen-year old Yeats, then it was clearly a different Jonson from the one we usually think of who became a stylistic model for this early verse-play, The Island of Statues. It was a Jonson more easily accommodated to Yeats's romantic "style" of oxpressing his thought.

This problem of accommodation is the same problem Yeats would later have to face with the sometimes sulfurous Jonson of the Enigrammes, The Forrest, Under-wood, the Ungathered Verse and such satiric plays as Volpone, The Alchemist and the Silent Woman. Since Jonson's The Sad Shepherd, as a pastoral farce reminiscent of Spenser, is so utterly unlike the greater body of Jonson's work, other uses of Jonson by the young Yeats hardly seem possible. Our problem, then, of accounting for Yeats's later use of Jonson's other work, in terms of the critioal beliefs and creative enthusiasms central to Yeats's art, is one Yeats solved for us by changing those things within his power to change-namely, the critical beliefs that were central to his art. The Yeatsian method for the union of antitheses, subjectivity and objectivity, life and art, "the old nonchalance of the hand" and the "Btyle" that "is found by sedentary toil/ And the Imitation of great masters" Prom "Ego Dominus Tuus," is a method we may consider speoially designed to accomplish such feats. Yeats, 
Indeed, recognized the difference, the very opposition in style, force of personelity, and reference in composition, between himself and Jonson. But Yeats was not only able to recognize the opposition; he was aotually able to approve and embrace 1t. As he became more like Jonson in his own style, the more he was able to absorb in his mind the classical "school" of Jonson, and the more he was able to ignore the fundamental difference between Jonson's classical method and his own romantic way of thinking. He was able to orystalize from the matter of both camps one universal idea of "the poet of imagination," an idea which will be illustrated shortly. A complicated mythology was evolved based on the movement and expression of the mask and several other crucial symbols.

By 1891, Yeats was already disparaging the philistinism of the dramatic audience of "this age" and taking steps toward transfusing the language of modern drama by advancing critically a littlo closer to the Renaissance example of Jonson and his friends.

The audiences that loved Ben Jonson's Masks, Chapman's Bussy D' Ambois or the love scenes of Old Fortunatus would have wished for more numerous set passages of poetio oratory, and more audacious metaphors; the Victorian public, on the other hand, by the mouth of a morning paper accustomed to pronounce its mandates, asks for more "matter of fact" conversations. 25

Yeats at this time was occupled with the composition of the poems from The Rose (1893) and the collection and composition of those stories and sketches from The Celtio Twilight (1893). He had recently written The Handerings of Oisin (1889). And his creative imagination would express 1taelf with additional and more elaborate imagery and 
aymbolic devices (dram partioularly from his mystical interests) before he would shift from the model of the Jonsonian masque, the poetry of elaborate event or spectacle, to the model of Jonson most representative of the poet and playright. But in this instence, like the earlier association of The Sad Shepherd and The Island of Statues, Teats was being selective in preference. And what he distinotly saw in the Elizabethan world, and liked, is what is, in fact, intensely romentic.

An Elizabethan would bave found it [the "wild, exotic and obscure". quality of the romantio play, The Poison Flower] all obvious enough, for bis age knew all the gamut of unhappy love from the deep bass notes of realism to the highest and most intense cry of lyric passion. It knew that romantic art alone when in 1 ts wildest and most fantastic mood can give us these lyrio intonations.26

A few years later Yeats would still be referring in his oriticism to the Jonson who wrote the Masques. Writing in Samhain 1905, Yeats praised Robert Gregory for the scenes he had oreated for his mother's play, Lady Gregory's Kincora.

Our staging of Kincora, the work of Mr. Robert Gregory, Was beautiful, with a high, grave dignity and the strangeness whioh Ben Jonson thought to be a part of all excellent beallty....27

The "strangeness" in beauty, achieved in effeot by the remaricable collaboration of Ben Jonson and Inigo Jones, was obviously attractive to Yeats who mentioned it frequently, in verse and prose. Yeats could have had on his mind any of numerous expressions Jonson gives to this idea in the Masques. For instance, in the Nasque of Blacknesse (1605): 
Here the Tritons sounded, and they danced on shore, euery couple (as they aduanced) seuerally presenting their fansi in one of which were inscribed their mixt Names, in the other a mute Hieroglyphiok, expressing their mired qualities. Whioh manner of Symbole I rather chose, then Imprese, as well for strangenesse, as relishing of antiquitio, and more applying to that originall doctrine of sculpture, which the Aestptians are said, first, to haue brought from the Aethiopians. 28

In Ermenzoi (1606):

Nor was there wanting whatsoeuer might give to the furniture, or complement; either in riohes, or strangenesse of the habites, delicacie of daunces, magnificence of the scene, or diuine rapture of musique. Onely the enuie was, that it lasted not still, or (now it is past) cannot by imagination, much lesse description, be recouered to a part of that spirit it had in the gliding by....

Ind of...the Attyreas that, of the Iords, had part of it (for the fashion) taken from the antique Greoke statue; mixed with some moderne additionss which made it both gracefull, and strange.29

And also in the anti-masque movement, in The Masque of Queenes (1609):

...last yeare I had an Anti-Masque of Boyes: and therefore, now, deuis'd that twelue Women, in the babite of Haggs, or Witches, sustayning the persons of Imorance, Suspioion, Credulity, \&c. the opposites to good Fame, should fill that part; not as a Masque, but a spectacle of strangenesse, producing multiplicity of Gesture, and not maptly sorting wh the current, and whole fall of the Deuise.....

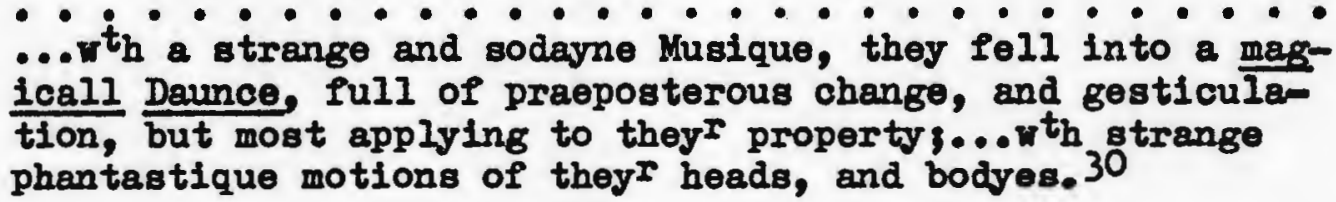

Yeats was not insensitive, by any means, to the effect of the anti-masque device, which gives fuller meaning to the impression of custom, ceremony and order (which are represented by the "Iyrical 
intonationg" of the verse-masque) by showing us the way in which the ideal world is real, how the falseness of the anti-masque demonstrates the truth of the masque. In Yeats's "Rosa Alchemica," written in 1897, the "flame-like figures" of the whirling dance-the "antique dance," the "magical danoe"-the shape "of living beings of an extraordinary beauty," "beautiful Grecian faces and august Egyptian faces" whose sculptured or painted mask-like "eyelids...never quirered," take up the mortal entourage of Michael Robartes into a horrible, lovely dance of intense passion and intense imagination. The interplay of dream and non-dream (or the anti-dream of reality), in this tale, seems so representative of the distrust of material existence because of Yeats's occultism that it is extremely difficult for us to conolude whether or not we, the narrator, or the author, are even capable of resolving the ambiguities we are given in the story. We are confused in trying to identify the speaker's ultimate ohoice between dream-reality and actuality. Will it be the anti- or ante-Christian dance of Eros? Or the Christian "voteens" who crash the ramshackle "Temple of the Alchemical Rose" and, we suppose, do unexpected violence to the blearmeyed sleepers? Both worlds are treacherous. Deception luriks everywhere. One finally supposes that It is the devotion of the follower, of the fanatic, that accounts for the similarity and confusion between the dancers and the angry shufflers, both of whom form the mingled legions at the end of this work, while the "many voices of exultation and lamentation... seemed to be ringing in the air over....head." The interpretation is supported by Yeats's statement elsewhere about "Greek proportions which 
carry into plastic art the Pythagorean numbers, those faces which are divine because all there is empty and measured"s and in regard both to the dancers and the superstitious mob, for the terror aroused in the narrator, "the mere multitude is everywhere with its empty photographic eyes." 31 In "Rosa Alchemica," while the narrator flees both antitheses, he rather desperately olings to that "manner of Sir Thomas Browne" in the middle, which has been the special maxk of his alchemical investigations, the mark of the akeptical believer. The function of masque and anti-masque are very important in this story. But as it often seems, it may be impossible to tell which is masque and which is anti-masque, since each play foil to the other and it is like seeking truth in a house of mirrors. There are other indioations in Yeats's story that Jonson and Yeats, for certain purposes of Yeats's creative imagination, may have been crossing paths. But these Indications must be set aside temporarily to develop other ideas.

In 1900, Yeats wrote an essay entitled "The Symbolism of Poetry," which was included in the collection of essays called Ideas of Good and Evil-each essay of which was completed between 1896 and 1903 and contributed to an investigation of art by way of a Blake-inspired vision of the antinomies of life, an investigation focusing on value, meaning, philosophy, and aesthetios. From the standpoint of Yeate's thinking in this period, the poet's job, according to the semi-autobiographical narrator of "Rosa Alchemica," is "the transmutation of life into are."32 In "The Symbolism of Poetry," Yeats discloses the way in which it is possible to unite Jonson's seventeenth- 
century, imitative use of tradition and Yeats's lyrio romanticism: a universal "poet of imagination" who has always worked with "the continuous indefinable symbolism which is the substanoe of all style."33

\begin{abstract}
All writers, all artists of any kind, in so far as they have had any philosophical or critical power, perhaps just in 80 far as they heve been deliberate artists at all, have had some philosophy, some oriticism of their art; and it hes often been this philosophy, or this critioism, that has evoked their most startling inspiration, oalling into outer life some portion of the divine life, or of the buried reality, which could alone extinguish in the emotions what their philosophy or their oriticism would extinguish in the intellect. They have sought for no new thing, it may be, but only to understand and to copy the pure inspiration of early times, but because the divine life wars upon our outer life, and must needs change. its weapons and its movements as we change ours, inspiration has come to them in beautiful startling shapes. 34
\end{abstract}

The "startling shape" of "melancholy beauty" expressed in a

line of poetry, which is subsequently the illustration of two linea from Burns, could have been as essily represented, if more prosalosl15, by a sentence published only one year later in "What is iPopular Poetry'?"-an essay of the same set.

Or go down into the street with some thought whose bare meaning must be plain to everybody; take with you Ben Jonson's "Beauty like sorrow dwelleth everywhere," and find out how utterly its enchantment depends on an association of beauty with sorrow which written tradition has from the unwritten, which had it in its turn from anoient religion... 35

Thls "enchantment" which owes its being to an assoolation which goes back to "ancient religion," beyond "written tradition," seems very olosely related for Yeats to the purpose of the "deliberate artists" In having a central "philosophy or oritioiam"-whioh is the "calling into outer life [of] some portion of the divine life, or the 
buried reality" "to understand and to copy the pure inspiration of early times." It is an idea that Yeats develops in the same year in "The Philosophy of Shelley's Poetry" (1900).36 And, at least partially, It resembles an idea that is also quite comonplaoe in Renaissance thought. Examples cen easily be found in the last two books of Boccaccio's Genealogy of the Gentile Gods (1371), 37 for instance, as well as in Sidney's An Apologie for Poetrie (1595) ${ }^{38}$ and in Jonson's Discoreries (1640). Although Jonson is not interested in the occult whys and wherefores, always of partioular fascination to Yeats, in the Discoveries, he writess

...the Poesy is the habit, or the Arts nay, rather the Queene of Arts: which had her Originall from heaven, recelved thenoe from the 'Ebrews, and had in prime estimation with the Greeks, transmitted to the Latines, and all Nations, that profess'd Civility. The study of it (if we will trust Aristotle) offers to mankinde a certain rule, and Pattern of livIng well, and happily....And, wheras they entitle Philosophy to bee a rigid, and austere Poesie: they have (on the contrary) stiled Poosie, a duloet, and gentle Philosophy, which leades on, and guides us by the hand to Action, with a ravishing delight, and incredible Sweetnes.... [But] wheras all other Arts consist of Dootrine, and Precepts: the Poet Lor maker] must be able by nature, and instinct, to powre out the Treasure of his mindes and as Senece saith,... by which hee understands, the Pooticall Rapture. And according to that of Plato 3.... And of Aristotles...Then it riseth higher, as by a divino Instinct, when it contemnes common, and knowne conceptions. It utters somewhat above a mortall mouth. 39

It is at this point, howerer, that another slight difference between romantic Yeats and classical Jonson is apparent-a difference worth aoknowledging, for it sets them in opposition to one another-though it is a difference, so far as Yeats was conoerned, of little significance, since both poets must fall into the sum of Yeats's conception of the unirersal "poet of imagination." For 
Ieats, the aotivity of the poet, in his labor to produce poems, is not so muoh a cause whereby he maneges, by instinot and wit and his own resources of energy and "that I oall Custome of speech, which is the consent of the Iearned," 40 to "powre out the Treasure of his minde" into an expression of "Poeticall Rapture" far and above what seemed his capacity to create ("... It gets a loft, and flies array with his Ryder, whether, before, it was doubtful to ascend"4l), but, according to Yeats's own account, it is an end within itself, one of those "beautiful states of being" the artist "tries to call up in himself" as though, by making himself habitable for the visitation of a ghost of Imagination, the creative act of the poet were reduced to a kind of mediumships

All sounds, all colours, all forms, elther because of their preordained energies or because of long association, evoke indefinable and yet precise emotions, or, as I prefer to think, call down among us oertain disembodied powers, whose footsteps over our hearts we call emotions and when sound, and colour, and form are in a musical relation, a beautiful relation to one another, they become....one sound, one colour, one form, and evoke an emotion that is made out of their distinct evocations and yet is one emotion. The same relation exists between all portions of every work of art, whether it be an epic or a song, and the more perfect it is, and the more various and numerous the elements that have flowed into its perfection, the more powerful will be the emotion, the power, the god it calls among us. 42

By this time, despite this difference in perspective the two poets have on the matter of poetic inspiration, Ieats is beginning to find the "gubstance," as he calls it, of Jonson's particular "style" compellingly attractive as a manly and heroic bludgeon egainst one's enemies and a comfort for one's noble friends. As in the example of his use of Jonson in the essay "What is 'Popular Poetry'?", he is be- 
ginning to use the older poet not just as an example of art above the masses, above the Victorian newspaper-reading audience, but also as an example of the kind of art good artists should emulate, against "the triviality of emotion, the poverty of ideas, the imperfect sense of beauty of a poetry whose typioal expression is in Iongfellow." 43 In poetry, Yeats calls for clear rhetoric. Principally a result of his new task as a playwright and co-founder of a national literary theater in Dublin, he becomes more and more interested in common opeech as the medium of literature, rejeoting the eighteenth- and nineteenth-century idea of a languege intringically and exclusively reserved for "poetry." All the while, he is beginning to show signs of taking over some of Jonson's contempt for the "cittie" merchants ("the masses" or "mob") frequently associated with Jonson's defense of the traditional values at Court and his loyalty to his aristocrat10 patrons.

A relation of mine has just written me a letter, in which he says: It is netural to an Irishman to write plays.... In these days an Englishman's dialogue is that of an ameteum-that is to say, it is never spontaneous. I mean in real life. Compare it with an Irishman's, above all a poor Irishman's reckless abandonment and naturalness, or compare it with the only fragment that has come down to us of Shakespeare's own conversation.' (He is remembering a passage in, I think, Ben Jonson's Under-woods). Petty commerce and puritanism have brought to the front the wrong type of Englishman; the Iive17, joyour, yet tenacious man has transferred himself to Ireland...'

(Sambain: 1901) 44

(These are his "relation's" words; but Yeats has caused them to be printed, because they reflect his own opinion.) A Jacobean comedy,

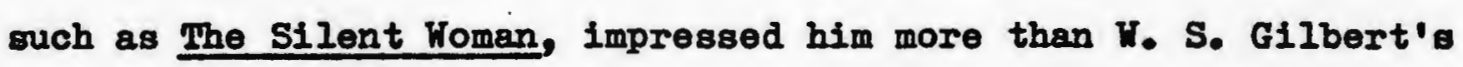
Palace of Truth, which by comparison was a bad play of the contempo- 
rary English stage that Yests once saw produced with Jonson's play; in contrast, details of the Silent Homan "were full of invention and vitality, and the language was like a torrent."145 And it is with this kind of enthusiasm that Yeats plunged into his deepest study of Jonson.

In 1906, from the evidence of hls correspondence and the content of his essays, Yeats had made a pretty thorough rereading of Jonson. By the time he wrote his publisher an inquiring letter about Jonson-noting his progress on a series of short essays then referred to as "my "Thoughts and Socond Thoughts'" and noting also his thought of writing an article on Jonson, like the one he had just finished on Spenser, or on "the ideal of life that flitted before the imagination of Jonson and the others when they thought of the Court"-Yeats could already say that he had gone to extensive lengths to study Jonson. 46 As a part of Yeats's Inquiry, he also asked Kr. A. H. Bullen about the possibility of Jonson's meaning Shakespeare, not Chepman, by the oharacter "Virgil" in The Pootaster. In Yeats's Shakespeare, Rupin Desai theorizes that Yeats had already made up his mind that this was in fact the case, though he nevertheless posed the question to Bullen. 47 At this late date (Soptember 21), It certainly does seem likely that Yeats's inquiry only represented a little last minute oheoking into matters conoerning the second installment of his essajs due to be printed in the Ootober number of Bullen's Gentleman's , Magazine. But it is not known, for sure, how far into the composition Yeats had already gone beyond the first installment of his "Thoughte and Second Thoughts," later published by Dun Emer (the 
press for which Yeats's sister Elizabeth was an editor) under the oover title Discoveries (1907).

T. Malindon has already noted the resemblance between the titles of Yeats's Discoveries (or "my 'Thoughts and Second Thoughts'") and Jonson's TIMBER: OR, DISCOVERIES; MADE VPON MEN AND KATIER: AS THEY have Plow'd out of his daily Readings; or had their reflure to his peculiar Notion of the Times. ${ }^{48}$ One should add further, horever, that Yeats, in his apparent attraction to the critical ramblings of Jonson's Discoveries, must also have found something agreeable in the literary custom the latter represents as a genre to have used it in his orm loosely structured prose explorations. Jonas Barish links Jonson's work with Donne's Devotions, Seldon's Table Talk and Traberne's Centuries of Meditations to a genre he calls "the penséeg"

... a disconnected series of jottings that explores a few dominant themes in as many ways as the writer chooses... [where] Truth is presented in fragments, in scattered glimpses, rather than steadily and whole... [and] technique.... implies groping, exploration, tentative forays; the vision is seen only intermittently and in pieces. 49

If Desai is right, in the sequence of composition and inquiry, and Yeats had already decided for himself the matter of the identity of Virgil in The Poetaster, then Yeats may have already witten the tenth foray of his Discoveries, "Why the Blind Man in Ancient Times was Made a Poet," before posing the question to Bullen who was a reputable Elizabethan soholar. ("Why the Blind Man..." was the last chapter of the unsigned Ootober installment in Bullen's magazino.) Indeed, all three of Yeats's most quoted images Prom Jonson appear in the very brief interval of this particular pensée. 
Ben Jonson says in The Poetester that even the best of men without Promethean fire Is but a hollow statue, and a studlous man will commonly forget after some forty winters that of a certeinty Promethean fire will burn somebody'B fingers. 50

Then The Silent Noman rammed a century of laughter into two hours traffic, I found with amezement that almost every journalist had put logic on the seat where our Iady Imagination should pronounce that unjust and favouring sentence her woman's heart is ever plotting, and had felt bound to oheriah none but reasonable sympthies and to resent the baiting of that grotesque old man. 51

There are indications, besides these, thet Yeats was thinking in terms that remind one of Jonson, in both the general and immediete contexts of these direct references to Jonson but, for the moment, our attention need only be fooused on the referenoes themselves. The passage in The Poetaster to which Yeats alludes ( $V, i, 14-16)$, in the first instance, 18 the folloring:

To shew, your titles are not writ on posts, Or hollow statues which the best men are, Without Promethean stuffings reacht from heavend 52

The Passage in The Poetaster to which Yeats alludes, in the second instance, participates even more actively in the expression of Yezts's thought when be writes:

E- himself, all musoular force ard ardour, makes me think of that line written, as one believes, of Shakespeare by Ben Jonson-"So rammed with life that be can but grow in life with being."

(The Autobiography, ce. 1909$)^{53}$

And, later, it is this same quotation from Jonson that Yeats places, little obanged, in a very different context. We have it in the diecussion of the inspirational ghosts, or Daimons, of Per Amica Silentia Iranae (1917): 
Awhile they live again those passionate moments, not knowing they are dead, and then they know and may awake or half awake to be our visitors... surely of the passionate dead we can but ory in words Ben Jonson meant for none but Shakeapeares "So rammed" are they "with Iife they can but grow in Iife with being."

$$
\text { ("Anima Kundi," XIV) } 54
$$

Actually, Jonson's lines are these:

[Ḧrace.] His learning labours not the school-like glosse, Thet most consists in eochoing wordes, and terms, And soonest wins a man an empty name:

$$
\text { (The Poetaster, V, 1, 129-31, 136-8) } 55
$$

"Rammed with Iife," "hollow statue," and "Promethean fire" are all essentially part of the same thing. Or rather, being but a "hollow statue" and being possessed by "Promethean fire" are opposite states of beings and "rammed with life" is a surplus of "Promethean fire." "Promethean stuffings reacht from heaven" "divine Intuition", "the power, the god it calle among us", "certain disembodied powers", "passion"; "startiling inspiration", "pure inspiration of early times, ...the divine Iife [warring] upon our outer life", or "our Iady Imagination"-any of numerous other names one might wish to associatewith this "Prometheam Pire" are opposed to the "hollow statue," whioh derives its meaning solely upon the absence of the former. If one happens to be Edrard ("E-, or "the Bishop") Bvens, then one will seem so motivated with a surplus of "Promethean fire" as to be "rammed with life" in overflowing abundance. If, however, one happens to be the unfortunate T. H. Bolleston, one may begin to feel the 
full weight of insult implied by the other.

I had been impressed also by his physical beauty, as of a Greek statue. This man, T. W. Rolleston, oame to be what Russell calls 'an intimate enemy', without passion, though in mind and in body he seemed a vessel shaped for fiery use, I came to think him, in Ben Jonson's phrase, 'a hollow image .56

Although generally the workings of these appropriated Jonsonfan metaphors seem simple enough, there are variations of these images that may sometimes give us trouble. And this may well be because of the way Jonson is incorporated into the normal expression of romantio imagination. Jonson, of course, didn't say "hollow image" (In the Rolleston instance), he sald "hollow statue." And when Yests later recalla, in Per Amica Silentia Lunae, the phrase, "a hollow image of fulfilled desire," a phrase "I remember or seem to remember" Irom Simeon Solomon, we may indeed wonder at the modification done to the phrase by the poet who is apparently quoting from memory. 57 We may wonder too, by association, how the phrase "hollow Imsgo," or "hollow statue," compares with that very early expression of it in oonneotion with the "masked" sleepers of "Rosa Alchemica," which was discussed earlier. The funotion of alohemy and the masque/ anti-masque, in Yeats's story, may partially account for a similarity there. But the fire of the alchemical furnace the candle burning beside the midnight bookman, the "glitter" of oyes "in the firelight, through the incense," of Michael Robartes' mask-like face; the superstitious watchmen sitting before a small fire "such as one sees slung under tinkers' carts", the ceremonious and passionate dance of dream and imagination among drifting figures with half-shut eyes who appear 
to be Love, but turn out to be Deception; the mask-like metamorphosis to the narrator as he falls in a dream and his subsequent waking in the morning to find "near me a soore of sleopers.... their upturned faoes looking to my lmagination like hollow wasks"-items like these certainly suggest that something is going on that Yeats would later be able to describe with reference to Jonson. But clearly, to reclaim order from our confuaion between the idea of a "hollow image" attributed to Jonson and "a hollow image of fulfilled desire" attributed to Simeon Solomon, - these would seem to be two very different things. One, in this instance, refers to impotenoy, emptiness, storility, the other, to a mesk-1ike object, an artist's image of "fulfilled desire," a representation of the artiat's reach for the antiself of "Ego Dominus Tuus," a poem-a threnody of passion. (Yoats leans, as was stated before, toward a preference for tragic art.)

All happy art seems to me that hollow image, but when its lineaments express also the poverty or the exasperation that set its maker to the work, we oall it traglo art. Keats but gave us his dream of luxury, but while reading Dante we never long escape the conflict, partly because the verses are at moments a mirror of his history, and yet more because that histgy is so clear and simple that it has the quality of art. 58

In this connection, over and over again, Yeats will use the expression "rammed with life" to describe the content of the work of Shakespeare-though not his external personality, which Yeats felt lacked all higblight, being but a perfectly reflecting "multiplying mirror" that, "through Mask and Image,....created the most passionate art that exists." 59 This matter will be taken up to a greater extent in the next ohapter. But it is important to note here, not only the 
apparent contrast in Yeats's viers of the personalities of Jonson and Shakespeare-public man, duelist and Reveler at Court versus the retiring man, "gentle Will"_, but also the ambiguities of this contrast which tend to set both Renaissance writers in the same Iight. In apite of other differences, together their Iiterature is packed with a vitality which presoribes to Yeats's borrowed model of "Promethean fire," of "life," in Yeats's peculiar sense of the word. The Sllent Woman 18, after all, admired for its abundance of "details... of invention and vitality," its torrential language, its compression of a hundred years of laughter in "two hours" traffic," the very ener$B y$ and abundance Yeats also admired in Volpone and The Alahemist. 60 Jonson was not referring to Virgil's (or Shakespeare's) capacity to regenerate himself in life, like "the passionate dead" who relive their finest, most passionate moments; but to the poesie, represented in published language, which gains a reputation for itself, beyond that then acknowledged, for its verbal intensity of lifelike expression. Indeed, it is often difficult to discern fixed limits of precise meaning in the Yeatsian sentence, because its author is always so willing to go this extra measure into the occult depths: But olearly, when both Algernon Charles Srinburne and John Addington Symonds aver to a "passionate Intensity" in Jonson, 61 it is not diffloult to believe that one aspect, at least, of Yeats's interest in Ben Jonson is based on an enthusiasm of the same sort. John J. Fnok, in Jonson and the Comic Truth, belleves that this being "rammed with life" does indeed strike a resemblence with the "passionate intensity" independently observed in Jonson by these two fellow Symboilsts. 62 
And Harold Bloom, in Yeats, confirms this by ultimately bringing down the romantic stamp:

Sholley, as elsewhere in Anims Mundi, provides the key to Yeats's discourses the "passionate dead" live only in our imaginations, and their dream is only our life. Alas that they do wear our colors there, though Yeats exultantly cries of them that they are rammed with life (itself a tag from another poet, Jonson)....here in Per Amioa Silentia Iunse be is more of a poet and less of a necromanoer, and he profits by his uneasiness, as do we. The Condition of Fire, with its purifying simplification through intensity, is preoisely the Romentic Imagination, the burning fountain of Adonais...63

Thus, we see why Yeats selected from Jonson these three images which work together to express this one ideas the idea itself stands as a monument at the center of all romantic art. If Jonson meant some other thing in the original context of his words, what is now the important thing, out of context and in Yeats's appropriation of them, is what they nor represent. Jonson is made to fit into a romentio system. But, though the system retains its integrity as a system, the experienoe will be that it will gain a new significance, in Yeats, through its association with this pugnacious and vigorous Jacobean.

And so the purpose in this first chapter has been to show how Yeats, working from an essentially romantic point of view, can nevertheless make accommodation for a writer like Jonson in the top circle of some ten or fifteen "most importent" writers. Though a writer most unlike the early Yeats, Ben Jonson can be made an instrument of radical change in Yeats's style by becoming one of the acceptable models for the "antithetical" process of life-oreating-art (working, in this odd sense, from one pole to the other). The change in style, 
or "personelity" represented in a maak of poetry, may be evident by 1914 in Regponsibilities, but the evolution of this change is indeed gradual-as eradual, maybe, as demonstreted by the critical process of accommodating Jonson. It is not to be supposed that Jonson is the most important figure in the achievement of this change that comes about. But he certainly is an important figure. I study of Yeats and his progress of thought similarly outlined by analogy with Donne, Swift, Shakespeare, Byron, Landor, Blake and, it is certain, many others, would possibly do just as well. But no one else provided a model for the emerging Yeats of quite the same character as Jonson, while at once contributing so much to Yeats's development of an ariotocratic myth. Of course, Yeats's study of Shakespeare and Spenser, in 1901 and 1902, would establish the idea of an alliance between aristocrat and poet and formulate his tragic vision of the Renaissance where the old unities were broken and trampled underfoot by an "inexplicable movement" of the multitude. To Yeats, however, Shakespeare was a retiring man who lacked personality and energy of his orm and Spenser พas an unvitting accessory and victim, in his Irloh affairs, to this "inexplicable movement." Only Jonson, of these three great men of the Fingliah Renaissance who mattered most to Yeats at this time, was an uncompromising-at times, daring-champion of courtly values, a scomful oritic of the unruly mob, and for this, of course, he was much admired by Yeats. But, to adequately demonstrate the extent to which all this is true, it will be nocessary, at this point, to turn to the next chapter. 
NOTES TO CHAPTER I

1 W. B. Yeats, Letters of W. B. Yeats, Allan Nade, ed. (New York Macmilian Publishing Co., Ino., 1955), pp. 478-9.

2 พ. B. Yeats, The Autobiography of William Butler Yeats (Hew Yorks Macmillan Publishing Co., Inc., 1974), P. 311. One probably deteots an air of similarity in tone and substance with Pound, as we have him in the Pisan Cantos. See note 3, below.

3 W. B. Yeats, The Colleoted Poems of W. B. Yeats (New Yorks Macmillan Publishing Co., Inc., 1974), p. 106. "September 1913" appears in the 1914 collection Responsibilities. Indeed, aooording to Noel Stook, Pound's biographer, The life of Ezra Pound (Ner Yorks Avon Books, 1974), p. 101, Pound and Yeats had met sometime in the middle of 1909. In a letter to Lady Gregory, postmarked July 16, 1913, Yeats speaks of "my experiment with Eara" in which the two had taken a cottage together and lived some months while trying out Pound as Yeats's secretary. Donald T. Torohiana and Glenn O'Malley, eds., "Some New Letters from W. B. Yeats to Lady Gregory," A Review of English Literature, vol. IV, no. 3 (July, 1963), p. 33. I will discuss this episode more fully at a later opportunity.

4 Francis Andrewes, "Jonson's Visits to the Peak," Ben Jonson, C. H. Herford and Percy Simpson, eds., vol. XI (Oxfords At the Clarendon Press, 1954), p. 388.

5 Such lists of influences can be found in T. R. Henn, The Lonely Tower (London: Methuen \& Co., Itd., 1965), P. Xil; and T. R. Henn, "The Rhetorio of Yeats," In Exoited Reverie, A. Norman Jeffares and K. G. W. Cross, eds. (New Yorks Maomillan Publishing Co., Ino., 1965), p. 106. Especially the latter is important in supporting the hierarohical ariangement, as I have it, which emphasizes these other influences above those actually Irish. Irish influences, Honn writes, without disclaiming their importance, stand in the background compared to these.

6 W. B. Yeats, "The Symbolism of Poetry," Essays and Introductions (New Yorks Collier Books, 1973), p. 159:

7 Giles W. I. Telfer, "Yeats's Idea of the Gael," No. IV of the Dolmen Press Yeats Centenary Papers (1965), p. 159.

8 Miohael Jamieson, "Introduotion," Ben Jonson, Three Comedies, Michael Jamieson, ed. (Harmondsworth, Bng.s Penguin Books, 1974), p. 10. 
9 S. B. Busbrui, Yeats's Verse-Plays, The Revisions, 1900-1910 (Londons Oxford Univ. Press, 1965), p. 208n, Hecolleoting an inter view, apparently, with Krs. Yeats, Bushrui writess "Mrs. Yests told me that Jonson was 'not one of Yeats's gods', but he read and admired him greatly."

10 T. S. Ellot, horever, in his essay "Ben Jonson," Ben Jonsons A Colleotion of Critical Essays, Jonas A, Barish, od. (Inglewrood Cliffs, N. J.: Prentico-Hall, Inc., 1963), p. 15, argues that "Jonson did not write a good tragedy, but we can see no reason why he should not have written one. If two plays so different as The Tempest and The Silent Voman are both comedies, surely the category of tragedy could be made wide enough to include something possible for Jonson to have done." Jonson, Fliot writes, as a writer of power and intelligence, "Is the legitimate heir of Narlowe" (p. 19).

11 Ben Jonson, Timbers or, Discoveries in Ben Jonson, Vol. VIII, C. H. Herford and Percy and Evelyn Simpson, eds. TOxfords at the Clarendon Press, 1954), pp. 643-4.

12 พ. B. Yeats, A Vision (New Yorks Collier Books, 1973), p. 84.

13 K. B. Yests, "William Blake," Uncolleoted Prose Br W. B. Yeats, Vol. I, John P. Frayne, ed. (New Yorks Columbia Univ. Press, 1970), p. 401. Teats oites the introduction to the fourth chapter of Blake's Jerusalem as the souroe of this quotation.

14 B. Ifor Evans, Tradition and Romanticism: Studies in Englioh Poetry from Chaucer to W. B. Yeats (Hamden, Conno: Archon Books, 1964), p. 19.

15 T. MaAlindon, "Yeats and the Bnglish Renaissanoe," PML, IXXXII (Nay, 1967), pp. 157-69.

16 Donald Darie, "Michael Robartes and the Danoer," An Honoured Guest, Denis Donoghue and J. R. Mulryme, ods. (Iondon Edward Armold, Itd., 1965), Pp. 73-87, and "Yeats, The Master of a Trade," W. B. Yeatg8 A Critical Anthology, William B. Pritobard, od. (Harmondsworth, Enges Penguin Books, 1972), pp. 299-308, The latter was originally published in The Integrity of Yeats, Denis Donoghue, ed. (1964).

17 Rupin W. Desai, Yeats's Shakespeare (Evanstons Northwestern Univ. Press, 1971).

18 Iouis Macneioe, The Poetry of H. B. Yeats (Iondons Oxford Univ. Press, 1941), p. 199. 
19 Mallindon, "Yeats and the English Renaissance," p. 168.

20 Ben Jonson, Disooveries in Ben Jonson, Vol. VIII, Herford and Simpson, eds., p. 625 .

21 Henn, "The Rhetoric of Yeats," p. 106.

22 Yeats, Collected Poems, p. 157.

23 W. B. Yeats, "A General Introduotion for my Work," Essays and Introductions, p. 510.

24 W. B. Yeats, "I Became an Author," Oncollected Prose By W. B. Yeats, Vol. II, John P. Frayne and Colton Johnson, eds. (New Yorks Columbia University Press, 1976), p. 508. The Island of Statues was included in the Dublin University Revier, April, May, June and July of 1885.

25 W. B. Yeats, "A Poetio Drama," Letters to the New Island, Horace Reynolds, ed.' (Cambridge, Mass.: Harvard Univ. Press, 1976), p. 216; originaily printed in The Providence Sunday Journal, $26 \mathrm{July}$ 1891.

26

Ibid.

27 W. B. Yeats, Explorations (New Yorks Collier Books, 1973), p. 181 and Plays and Controversios (New Yorks Macmillen Publishing Co., Inc., 1924), p. 139. Samhain, Beltaine and The Arrox were all titles of tracts or newsletters published each year, reporting the dramatic progress and critical dicta of the Abbey Theatre principals (Yeats, Lady Gregory, Lennox Robinson, or some others). Often, as In the case of The Arrow, these tracts were quite brief and could be attached to a programme and distributed at the gate.

11. $266-74$.

28 Ben Jonson, Vol. VII, Eerford and Simpson, eds., p. 177,

29 Ibid., p. 229, 11. 572-9 and 584-6.

30 Tbid., p. 282, 301, 11. 15-22, 344-6 and 351 .

31 Yeats, Explorations, pp. 434, 451 .

32 w. B. Yeats, Mythologies (New Yorks Collier Books, 1974), p. 267. 
33 พ. B. Yeats, "The Symbolism of Poetry," Essays and Introduations, p. 155 .

34 Ibid., pp. 154-5.

35 W. B. Yeats, "What is 'Popular Poetry'?" Essays and Introductions, p. 7. "Beauty like sorrow dwelleth everywhere," attributed to Jonson, is a difficult reference to locate. I have not been able to detect its whereabouts in any of the Masques. It looks as though it could be a title or a first lines but, if so, certainly not from the Poems or any of the songs which come out of the Plays-at least, to my knowledge. J. H. Pollock, in Hilliam Butler Yeats (Dublins Talbot Press, Ltd., 1935), who quotes extensively from this particular passage, does not give a reference for it. And at this point I am inclined to believe Yeats is calling attention here only to the "thought" expressed in this one line. However, though not ideal, the documentation given this line by its association with Jonson's name is a good deal better than in the instances where Yeats tells us "...somebody of reputation, whose name I cannot remember, wrote... [something]" (Essays and Introductions, p. 104).

\section{6 и. B. Yeats, "The Philosophy of Shelley's Poetry," Essays} and Introductions, pp. 65-95.

\section{Giovanni Boccaccio, Boccaccio on Poetry 8 Being the Preface} and Fourteenth and Fifteenth Books of Boccaccio's Genealogia Deorum Gentilium, an English version with Introduction and commentary by Charles G. Osgood (New York: The Liberal Arts Press, Ino., 1956), pp. xvi, xxix, xuxv, xxxvil-xuxviii, xlv-xlix, 24-26, 33, 37, 32-46, 121-129. "This poetry, which lgmorant triflers cast aside, is a sort of fervid and exquisite invention, with fervid expression, in speech or writing, of that which the mind has invented. It proceeds from the bosom of God... This fervor of poesy is sublime in its effectse it impels the soul to a longing for utteranoes it brings forth strange and unheard-of oreations of the mind $[397$... Furthermore poetry, such as the poor poets have chosen to cultivate, constitutes a stable and fixed science founded upon things eternal, and confirmed by original prinoiples; in all times and places this knowledge is the same, unshaken by any possible change [25].... If you inquire, $0 \mathrm{King}$, under what aky, in what period, and by whose agency Poetry first came to light, I hardly trust my ability to answer. One group of writers thinks it arose with the holy rites of the Ancients, that is among the Hebrews, since Holy Hrit records that they were the first to offer sacrifice to God $[42]$..."

\section{Philip Sidney, An Apology for Poetry, or, The Defence of} Poesy, Geoffrey Shepherd, ed. (Iondon: Thomas Nelson and Sons, Itd., 1965), pp. 98-102. "Among the Romans a poet was called vates, which is as much as a diviner, foreseer, or prophet, as by his conjoined 
words vatioinium and vatioinari is manifest: so heavenly a titlo did that excellent people bestow upon his heart-ravishing knowledge 98 .... And may not I presume a little further, to show the reasonabIoness of this word rates, and say that the holy David's Paalms are a divine poem? $297 \ldots$ The Greeks called him 'a poet', which....cometh of this word polein, which is 'to make' $927 \ldots$.... any understanding knoweth the akill of the artificer standeth in that Idea or fore-conceit of the work, and not in the work itself. And that the poet hath that Ides is manifest, by delivering them forth in such excellency as he hath imegined them. Which delivering forth also is not wholly imaginative, as we are wont to aay by them thet build cestles in the alr.... but rather give right honour to the heavenly Maker of that maker, who having made man to His own likeness, set him beyond and over all the works of that second nature: which in nothing he showeth so much as in Poetry, when with the force of a divine breath he bringeth things forth far surpassing her dolngs... [101]."

39 Ben Jonson, Disooveries in Ben Jonson, Vol. VIII, Herford and Simpson, eds., pp. 636-7.

40

Ibid., p. 622.

41

Ibid., p. 637 .

42 Yeats, "The Symbolism of Poetry," Essays and Introductions, pp. $156-7$.

p. 6. 43 Yeats, "What is "Popular Poetry'p" Essave and Introductions,

p. 6. 43 Yeats, "What is 'Popular Poetry'p" Essays and Introductions, p. 13.

44 w. B. Yeats, Explorations, p. 81 , Plays and Controversies,

45 Yeats, Letters, p. 450. pp. $478-9$.

46 Yeats, letter to A. H. Bullen, 21 Sept. 1906, Letters,

47 Desai, Yeats's Shakespeare, pp. 39-40. On the dispute orer the "true" identity of Jonson"s Virgil in The Poetester (Shakespeare or (hapman?), Desei reports that such speculation was not original with Yeats in his day. Sidney Ire's A Life of William Shakespeare (Iondon, 1898, see Letters, p. 449), which Yeats may have read, argues in favor of Shakespeare. "When Poel produced Poetaster in Iondon on April 26, 1916," mrites Desai, "Virgil appeared as Shakespeare," as Herford and Simpson report (Ben Jonson, Vol. I, pp. $432-$ 37). Desai says it is possible Yeats could have viewed this spectacle, but of course that would have been ten years later than his 
Inquiry and seven years after his first definite statement to that effect was penned (oa. 1909) for bis Autobiography. See note 53, below.

48 MoAlindon, "Yeats and the English Renaissance," p. 164.

49 Jonas A. Barish, Ben Jonson and the Ianguage of Prose Comedy (Cambridge, Kass.: Harvard Univ. Press, 1967), p. 77.

50 W. B. Yeats, "Why the Blind Man in Ancient Times was Kade a Poet," Discoveries; a Volume of Essays (Dundrums Dun Emer Press, 1907), pp. 21-22; Essays and Introductions, P. 278. See also T. McAlindon, "Yeats and the English Renaissance," p. 164, where McAlindon observes that "Certain referenoes to Poetaster, Cymthia's Revels, and The Silent Homan in 'My Thoughts and Second Thoughts' (1906) suggest...that Yeats was also interested in Jonson as the type of pre-modern poet whose vigorous comic art proceeded from a contemptuous indifference to mere logic and general approval." MoAlindon's observation is based on the same resources I have used here in presentation.

\section{1}

Yeats, Essays and Introduotions, p. 280.

52 For the precise location I am indebted to Rupin Desai, Yeats's Shakespeare, p. 40. Desal adds that "Yeats refers to the play [Poetaster/by drawing attention to Caesar's noble lines on the poetic imagination that can illuminate a man's life and give added glory to his other achievements... [quotes V, i, 13-16] Yeats then gives examples of this Promethean fire, without which even the best of men is 'but a hollow statue,' and finds it ablaze in Shakespeare, Tintoretto, men whose 'minds were never quiescent' but 'alweys in exaltation.' The tremendous creative energy of a Shakespeare could suitably answer to Jonson's description of the oondition of inspiration."

53 w. B. Yeats, "Estrangement," The Autobiography, p. 325. In Memoirs; Autobiography - First Draft \& Joumal, transoribed and odited by Denis Donoghue (New York: Macmillan Publishing Co., Inc., 1973), p. 165, E- is identified as Edward Evans, nicknamed "the Bishop," and all but the exsot wording of Yeats's approximation of Jonson's Poetaster lines $(V, 1,136-7)$ is held intaot. The date for the Journals where this appears Donoghue gives as January to March, 1909.

54 Yeats, Kythologies, p. 360.

55 In Yeats's speculation about these Pootaster lines and his occult bearing on the subsequent use of them in "Anima Mundi," I am thankful for the remerks of Peter Ure, Ho Bo Yeats and the Shakespearean Moment (Belfasts Queen's University, Belfest, 1969), p. 17 : 
"If we get our mythologies mixed up down there, there is some excuse for us. And yet if Jonson was thinking of Shakespeare when he wrote of the life which Virgil's poetry is rammed, he can bardly have been thinking of life in that sense."

56

Yeats, Memoirs, p. 9.

57 Yeats, Mythologies, p. 329.

58 Ibid.

59 Yeats, A Vision, p. 153.

60 Yeats, Explorations, p. 225.

61 Algernon C. Swinburne, A Study of Ben Jonson (London: Chatto \& Windus, 1889), p. 35; John A. Symonds, Ben Jonson (London: Longmans, Green, and Co., 1888), D. 74 .

62 John J. Enck, Jonson and the Comic Truth (Madison, Wis.s Univ. of Wisconsin Press, 1959), pp. 11-12.

63 Harold Bloom, Yeats (New Yorks Oxford Univ. Press, 1970), p. 189. 
CHAPTER II

THE PIAYS: AN APOIOGY FOR POETRY

When T. S. Ellot was being acclaimed as the author of "the first great poetic play since the Jacobean age," ${ }^{1}$ Murder in the Car thedral, he reminded his audiences "It is to Mr. Williem Butler Yeats more then anyone else that we owe the revival of poetio drama in our times." ${ }^{2}$ Indeed, Eliot's admirers needed to be reminded of this debt; for the unpopular plays of Yeats had seldom drawn as much attention from playgoers in their day, for example, as did the farces of Iady Augusta Gregory performed in the popular "Klltartan" vernacular of the west of Ireland and the direction for which Yeats strove with his plays was opposite that general direction toward realism even his own Abbey Theatre was taking with Synge and O'Casey. As Peter Ure explains, ${ }^{3}$ except for the Irish plays written before 1915, modern theater had "simply decided" that Yeats's later and most charaoteristic, if not most important, plays could not be "fitted in." And furthermore, Ure maintains, beoause of the extension of this judgment by modern theater to also include such obvious "masters of the stage and audienoe" as Ben Jonson, Thomas Middleton and G. B. Shaw (the latter, as the judgment applies, in England but not, apparently, in America), this judgment against Yeats deserves our cautious and slightly suspicious consideration. It may be no accident, therefore, that when we think of Yeats, we think of him as a poet and seldom as a playwright, though, for the record, the volume of his creative rork 
was fairly evenly divided between these two forms.

Not long after Eliot had paid his respeots, Una Ellis-Fermor, in The Irish Dramatic Movement, 4 published her general account of Yeats and the background of the theater of his day, the account whioh has set the tone for most of our recent criticism. Ellis-Fermor's Yeats is portrayed as a discontented playwight who, conoerned with the type of drama he was about to rrite, was confronted by choioes similar to those later defined by George T. Wright in The Poet in the Poem. According to Ellis-Fermor, it was a choice of

following Ibsen in the serious prose discussion play or degrading him in the automatic problem play, following the Elizabethans at long distance in the pseudo-poetio play or continuing the more reoent traditions of faroe, domestio melodrama or the French 'pièce bien faite.' 5

Similarly, Wright observes what happens to the literature of an age when the romentic writer imposes his own personal identity onto that voice of the singer or those speeches of the dramatis personee from the theater:

Tragedy drowns in its now single dimension; melodrame, purporting to present actuality, gradually takes over the stages even comedy, in order to keep its distanoe from actuality, a distance that the audience finds it increasingly hard to grant, must verge on farce...6 6

Joining Eliot, but with much more lavish compliment, Ellis-Fermor's tribute to Yeats is that,

with no help from any dramatio tradition then at work in Europe, he] led the drame of the English-speaking people back to the paths of poetry and power, making way...for the first body of plays which can seriously compare with the Elizabethans. 7 
And, she adds,

To do this by imitation was imposeibles be kner, no less than Ben Jonson, that 'Ilkeness is alrays on this aide truth'. It must be raised again from the earth, not in its material or its form or Its language only (though he provided for all of these) but in the spirit. His determination to return to the thought and epeeoh of the people was more than a wise appreolation of a hitherto unexplored field, it was an instinotive recognition of the roots of poetio truth. He believed that the drama must be born again or perish utterly, for it had reached the phase known fo contemporary biologists as 'the old age of the speoies'.8

We have seen, in the previous chapter, that Yeats had undertaken a pretty thorough rereading of Ben Jonson by the middle of the first deoade of this oentury. T. McAlindon cites two arguments, based upon the substance of Yeats's September 21, 1906 letter to A. H. Bullen, 9 for belleving that Yeats's study of Jonson's work was Indeed Intensive. In the first plaoe, MoAlindon asserts, interests expressed in the other Jecobean writers mentioned in the letter, nameIy Marston and Dekker, were interests to Yeats "solely beoause they were chief among the detraotors and rivals whom Jonson satirized in Everyman out of his Humour, Cymthia's Revels and Poetaster."10 Seoondly, MoAlindon stresses the Intensity with whioh Yeats followed up his ouxiosity, expeoialiy on such now minor details as "the various people the plays are dedioated to, and the various ladies one lights upon In Ben Jonson's Masques," having pursued such matters to the point of "dipping into Clarendon."11 From the same letter, we also learn, upon Yeats's admission, that, until that time and with the two important exoeptions of Shakespeare and Spenser (whom he read continuously), Yeats had not "read the Elizabethans in fifteen years," And 
this point ought to be made with the sense of some significance. If Yeats, in the course of his work for the theater, was to have this miraculous effect of turning "the drama of the Bnglish-gpeaking people back to the paths of poetry and power," and if, while doing so, Jonson was suddenly to assume a significance comparable to that of Spenser and Shakespeare, writerg of the English Renaissance who have surely modeled for Yeats the material, form and language that was to be "raised again" in spirit, it ought not only to be posaible, but important to demonstrate how Jonson could have similarly helped Yeats change this direction. Like the oritioal accommodation of Jonson by Yeats, the importence of Jonson with respect to Yeats's plays is not simply something that inoreases overnight. As Ellis-Fermor points out, Yeats's "determination to returm to the thought and epeech of the people... was an instinctive recognition of the roots of poetio truth." Again, we seldom think of Yeats but as a poet. But the interesting thing about Yeats's use of Jonson as a model for the revival of poetio drama is the way in which the most outstanding examples of similarity between the two playwrights seem to defend as well as advance the Yeatsian poetic (somehow always at least partly the subject of a Yeats play) along aristocratio lines. Yeats's myth of the aristocracy, perbaps politically unfortunate but poetically fruitful, was founded on some very Jonsonian grounds, grounds which, of course, were but gradually approached by the Irish playwight.

For Instance, when Yeats praised the audiences who had, because of their wish "for more numerous set passages of poetio oratory,... loved Ben Jonson's Masks" and contrasted this praise with bis dis- 
pleasure with the Victorian newspaper-reading publio and their taste for matter-of-fact conversation, Yeats did not here it immediately in mind to write above the heads of the Viotorian audienoe, giving them, whether they liked it or not, the "highest and most intense ory of Iyrio passion" none but an Elizabethan could appreciate. 12 Yeats's earliest plays to be performed on the stage, The Countess Cathleen (1892), The Land of the Heart's Desire (1894) and Cathleen N1 Houlihen (1902), were plays Yeats wrote with a specifically Irish, intensely nationalistic and popular audienoe in mind. These were plays which were meant to be the implementation of their author's hopeful strategg of "seal[ing] with the right image the soft wax before it began to harden,"13 the underlying purpose of what Yeats and his friends called the Celtio Wrilight. John Unterrecker points out that this "Image" Yeats sought for modern Ireland was in fact " the myth-founded Mask of Ireland whioh, being opposite to the modern world, was the Mask for the modern world." 14 Yeats was very muoh concerned that this modern Irish Mask be acoessible to all the people, as he believed had been the case when Homer oreated The Iliad and The Odyssey and the classio playwrights of Greece and Rome had written their masterpieces. Yeats was, at this time, interested in discovering a measure of popularity, a "popular poetry," a "popular beauty" which escapes the use of artificially "poetio" language, finding instead "beautiful startling shapes" from the buried reall ty of the individual and the Great Kemory of mankind, a poetic drama which could be pleasing to both the sophisticated litterateur and the simple peasant because of its "strange" simplicity stemming from the common roots of 
all human minds. And at this time, this meant that Yeats would try very hard to conoeive of those shop-keepers and middle-olass merchants as an important part of his audience to entertain. (For "entertain," one could almost substitute the word "instruot," in the sense we have of instruction-sometimes hardly aware of it-in Jonson's theater. To "seal with the right image the soft wax..." The most appropriate word is probably "inspire.")

\section{DISCOVERIES, IEATS AND THE IRISH PLAYERS}

In the first 1906 Discoveries essey, "Prophet, Priest and King," 15 Yeats desoribes a startling experienoe he had had while on the road with his "little theatrical company." The repertory Broup was scheduled to perform one of their current plays about the heroic life of ancient Ireland and had agreed to do it in the old ballroom of a small tow in the west of Ireland. The setting or background for the disoovery of the essay is exceedingly important, for well over half the essay is deroted to it-the half-ruined, half-finished state of the ballroom, the town, the convent schools and the nearby cathedral; the "strangeness and simplicity" of the work of some young Irish soulptors, in carving the cathedral's altar and pillar-heads, set beside "the meretrioiousness of the arohetecture and commonplace of the inlaid parement"; "the worst of the old and the best of the ner....side by side without any sign of transition." Given such a frame for the birth of an idea, Yeats then describes the half-drunken though attentive and respectful audience which attended the performance of this play and the ironically joyful discovery of the play's 
inadequacy in the context of such an audience. The play was a failure for these simple people, because it really had very little to do with the subjeot it professed, namely heroic Ireland of the past, but ererything to do with the "sedentary refinements and the spirituality of the cities."

Fvery emotion was made as dainty-footed and dainty-lingered as might be, and a love and pathos where passion had faded into sentiment, emotions of pensive and harmless people, drove shadowy young men through the shadows of death and battle. I watched it with growing rage... Thy should we make so muoh nolse about ourselves and yet have nothing to say that was not better said in that workhouse dormitory, where a fer flowers and a few coloured counterpanes and the colourod walls had made a severe appropriate beauty. 16

As Yeats writes, the office of playwright is identical with that of poet and priest. Because the English have driven off the Irish kings and changed all her prophets to demogogues, only these poet-priests are left to inspire the peoples and, in order to do that, they must, as Yeats speaks in their behalf, "reintegrate the human spirit in [theix] imagination." 17

In the essays of Discoveries following this one, Yeats investigates, at considerable length, this matter of "reintegrating the human apirit" that his imaginative work might "mean something to vigorous and simple men whose attention is not given to art but to a shop, or teaching in a National Sohool, or dispensing medicine. ${ }^{18}$ what moves a man in the arts is what moves the same man or any man in life, Yeats concludes, "Intensity of personal life." And so Yeats presents literature with two choices before its it must either move 
upward into ever-growing subtlety...until at last, it may be, a new agreement among refined and studious men gives birth to a new passion, and what seems literature becomes religions or downward, taking the soul with us until all is simplified and solidifled again. 19

Shelley's Chapel of the Morning Star and the kind of art which is a hybrid of Iiterature developed with reference to a convention of aymbols, to Iiterary life, by "refined and studious men" represent the direction of the first choice. The second, though the way of the market cart, is also the way of "Villon the robber," "Burns's beerhouse," Verlaine's "delight in singing his ow Iife," Ben Jonson's "Promethean fire" (whioh Yeats opposed to "all that impersonal fecunity which muddies the Intellectual passions" ${ }^{20}$ ), Don Quixote, Odysseus and Palstaff. This second choice is the one that Yeats made at that time. And, in this office of poet-priest for his people, there is nothing lost in the movement dows for,

When all art was struck out of personality, whether as in our daily business or in the adventure of religion, there was little separation between boly and common things, and just as the arts themselves passed quickly from passion to divine contemplation, from the conversation of peasants to that of princes, the one song remembering the drunken miller and but half forgetting Cambusoan bold, so did a man feel himself near sacred presences when he turned his plough from the slope of Cruachmaa or Olympus. 21

Throughout Discoveries, Yeats displays his increased preoccupation with the idea of a written art which reflects the whole personality, energy and kind of personal, subjective perception of truth whioh is as quick and illogical as lightening. And in doing this, he makes a distinct break with his former praotice. 
Without knowing it, I had come to oare for nothing but impersonal beauty. I had set out on life with the thought of putting vy very self into poetry, and had understood this as a representation of my own visions and an attempt to cut away the nonessential, but as I imagined the visions outside myself my imagination became full of decorative landscape and still life.22

The subject-matter of this new kind of art for Yeats cannot be discovered by deliberate intellect, but by a kind of "thinking of the body," the integration of the whole personality. The worst drama, therefore, to have captured the world's attention is the drama which is centered on modern educated people, people who "have no artistic and charming language except light persiflage and no powerful language at all."23 Peasant language had been a growing enthusiasm of Yeats's since the time he had canvassed the countryside for his Irish folktales of The Celtic Pwilight (1893); and it was beginning to seem the choice language for this task of moving (entertaining, instructing or inspiring) his people toward accepting his heroic Mask for the modern world. Like the quality of Homer's Iliad and Odyssey of being "the swift and natural observation of a man as he is shaped by life,"24 and like Chaucer's Canterbury Pales, fine literature has something of the quality of "an old wires' tale"; and its authors "are like an old peasant telling stories of the great famine or the hangings of 198 or from his own memories." 25 It is at this time that Yeats began simplifying his Pateresque prose style by enlisting, in 1907, the aid of Lady Gregory to help him rewrite his 1897 Stories of Red Hanrahan. The "Kiltartan" idiom, which is the most obvious evidence of the very close working relationship of Yeats and Lady Gregory in the first decade or so of Yeats's work for the Abbey Theatre, 
seemed an answer to the modern need for a language as rich, immediate and exciting as the city English of Jonson's Alchemist or Bartholomer Fair. The "Kiltartan" English of the people living about the area of Lady Gregory's Coole Park estate, was said by Yeats to have had all the startling beauty and dimension of the English of Iondon at the time of James's court, while possessing a novelty of expression owing to Its Grelic arrangement of words. At this time, Yeats and Lady Gregory would mark perhaps their highest point of dramatic collaborar tion by co-authoring the play Unicomn from the Stars (1907). 26

But the most important discovery of Yeats's, as well as the most effective dramatic influence at this time on his art, was John Millington Synge. Synge, of course, had taken Yeats's advice and had gone off to study the peasant life and speech of the Aran Islanders to the west of Ireland. But already, by the time of Yeats's first introduction to Synge in Paris, in 1896, Synge had been busy filling his notebooks with imitative experiments based on Villon, Ronsard, Racine and other writers from the continent (especially medieval and Renaissance French writers) to whom Yeats would later attach more significance. To these attempts Yeats was to direct his stern judgment and, consequent2y, his sound therapeutic advices these poems and essays of Synge's were

full of that kind of morbidity that has its root in too much brooding over methods of expression, and ways of looking upon life, which come, not out of life, but out of literature, images reflected from mirror to mirror. 27

With his stories of The Secret Rose, Stories of Red Hanrahan (Iater put into the common speech with Lady Gregory's aid), The Tables of 
the Law and The Adoration of the Magi, all appearing in 1897, two years before Wind Among the Reeds and a year after this first meoting with Synge, it seems likely that Yeats's advice to Synge might have refleoted something corrective in mind for his own work, especially gince Yeats himself "had just come from Aran." 28

But in addition to Synge's compliance with Yeats's advico and consequent discovery of the way to express his own personality through living characters who seem to "pass by as before an open window, murmuring strange, exciting words," 29 Synge passed on to Yeats one of his considerable enthusiasms: Jonson. Douglas Dunoen, in his essay "Synge and Jonson (with a parenthesis on Ronsard)," reports that

A generation of Engliah readers was introduced to Synge in the Preface by Ernest Rhys to his Everyman edition, where an echo of The Silent Woman is incongruously heard in The Shadof of the Glen, and Volpone and Bartholomew Fair are oited among the four comedies which "counted" for Synge "In his salad days." More authoritative, to quote only two examples, have been Corkery's statement thet Synge had "steoped himself in Ben Jonson", and the portentious utterance of Raymond Williams, writing of The Playboy of the Western World, that "the reference back is to Moliere, to Cervantes, perhaps to Rabelajis. Bven more certainly the reference back is to Jonson." 30

And not only have other similarities between the plays of Synge and Jonson been notioed-partioularly by Duncan, Alan Prioe, John J. Fnck, Maurice Bourgeois, Peter Ure, S. B. Bushrui and Jones A. Bariah 31 -but we are also made aware that synge made attempte to express the "exciting congeniality of spirit" he found in the literature of the seventeenth century, in the poems of Jonson and one of the "Sons of Ben," Herxick, by writing oocasional verse of his own, that Synge tried to reinvigorate poetry, not by imitating these po- 
ets, but by doing the very thing they did. 32 Duncan argues that Synge's aim of writing an exalted "poetry of ordinery things" ("there is no timber that has not strong roots among olay and wormsin33) part Iy disposed him to write his slender volume of poems in the informalIy organized fashion of the Renaissanoe syltae, exemplified by "the Bocages of Ronsard, the Divers Jeux Rustiques of Du Bellay and the Under-woods of Ben Jonson." 34 But, besides these notices from other oritios, we have Yeats's own word on it, long after the Pleyboy furor had subsided, that "Bartholomew Fair was one of the things that inPluenced Synge." 35 And Duncan, for one, belleves Bartholomer Fair, of all Jonson's comedies, the one that resembles most olosely the comedy of Synge (best represented by The Tinker's Wedding and Plavbor of the Western World) for its colorful prose based on popular idiom and its "handling of serious issues in a way which Synge would call 'Imaginative' rather than 'didactio'."36 The "living speech," such as one hears "in all the great literary moments," "that was in the ears of Cervantes and Ben Jonson," Synge himself wrote in a draft of his Preface to The Playboy (January, 1907), "teemed with phrases that surpass anything produced by the Goncourts." 37 Just as Yeats's receptivity to Synge's enthusiasm for Jonson is evident in Yeats's September 21, 1906 letter to his publisher, where Yeats discloses a steeping of himself in Jonson (after Synge's example), so this joint influence of his working association with Synge at the Abbey Theatre and Yeats's orm reading of Jonson would have the profound effect of introduoing a new element to Yeats's work-humor-a particularly novel aspeot, at this time, oonsidering the melancholic and generally 
tragic moods of Yeats's early poetry. For Synge, humor is one of the ohief foods of the imagination; without it, a country or an individual suffer a "morbidity of mind." In his Preface to The Tinker's Hedding (December, 1907), Synge writes,

The drame is made serfous-in the French sense of the wordnot by the degree in which it is taken up with problems that are serious in themselves, but by the degree in which it gives the nourishment, not very easy to define, on which our imaginations live. We should not $g^{\circ}$ to the theatre as we go to a chemist's or a dram-shop, but as we go to a dinner where the food we need is taken with pleasure and excitement... ...Analysts with their problems, and teachers with their systems, are soon as old-fashioned as the pharmacopoeia of Galen-look at Ibsen and the Germans-but the best plays of Ben Jonson and Moliere can no more go out of fashion than the blackberries on the hedges. 38

Of course, as Dunoan asks, we may wonder why Synge embraced Jonson and not, say, Shakespeare, if it was Synge's ambition to lose that "kind of morbidity that has its root in too much brooding over methods of expression," when it was commonplace at this time to critloize Jonson, the maker of Art, for not being Shakespeare, the poet of Nature. The compliment, for example, paid to Volpone by Swinburne and Symonds, for 1 ts "touch of something like imagination," 39 "passionate intensity," 40 is half taken away by the "cold oynioism" and "implacability"4l attributed to Jonson as he marshals his plot and characters toward the realistio and unromentio judgment ever the object of satire. Even Yeats, for all the particular enthusiasm he displayed for Jonson's Volpone, 42 felt that the lack of "marriage bellg" in the end for Celia and Bonario, a reward for their innocence and virtue, "makes us share in Jonson's cold implacability." ("His tribunal is private, that of Shakespeare's public." "Shakespeare and 
the ballads judge as we would have them judge." $)^{43}$ Duncan's conolusion is that Synge's choice of Jonson as a model for his own art "would seem to underline Synge's awareness of the high degree of deliberate art involved in his own collaboration with nature."44 And the passage which replaced that of Synge's draft for The Plarbor Preface, which had linked Jonson and Cervantes as artists who provided "great literary moments" with a "living speech," seems to share something with Yeats's conoeption of fine literature like "an old wives' tale" or an old peasant's stories; the linguistic comedy of Jonson's Volpone, The Alchemist or Bartholomew Fair, achieved through Jonson's colorful commend of Jacobean English, is a "collaboration" of people and playwright, from Synge's point of view, and, just so, it may represent the type of invigorating "startling beauty" Yeats wanted to discover by "reintegrat [ing] the human spirit in...imagination,". "taking the soul [down] with us until all is simplified again."

All art is a collaboration; and there is little doubt that in the happy ages of literature striking and beautiful phrases were as ready to the story-teller's or the play-wright's hand as the rich cloaks and dresses of his time. It is probable that when the Elizabethan dramatist took bis ink-horn and sat down to his work he used many phrases that he had just heard, as he sat at dinner, from his mother or his ohildren ...it is possible for a writer to be rich and copious in his words, and at the same time to give the reality, which is the root of all poetry, in a comprehensive and natural form. 45

Yeats's attitude toward Synge and his art, though always enthuslastic, displays a kind of ambiguity when he compares Synge with Shakespeare and Jonson, models who, evidently in Yeats's estimation, were not always opposed. In the last chapter, it was shown, for instance, how Yoats repeatedly pronounoed that Shakespeare was the sub- 
ject of Jonson's phrese in The Poetaster, "so rammed with life," while it was also pointed out how Yeats admired Jonson's great comedies for their abundance and vitality "rammed" into a very tight package. If it is commonplace to criticize Jonson for the deliberateness with which he produced art-and indeed this was done by nineteenth-century figures such as Swinburne and Symonds-yet its compressed "life" is not unlike the nature Shakespeare reflected in that "multiplying mirror" of his, his adept juggling of "Mesk and Image" which produced "the most passionate art that exists." And Yeats's opinion of Synge seems to reflect Yeats's somewhat ambiguous thoughts about these two poet-playwrights of the English Renaissance. On the one hand, when writing about Synge, Yeats made repeated allusions to the Poetaster metaphor of "Promethean fire" and "life" in much the Way it was used in the context of Yeats's Per Amica Silentie Iunae, where the "passionate dead" live on in the imaginations of the living. Yeats's eulogistic "Preface to the First Edition of John M. Synge's Poems and Translations" puts Synge in almost the same light as Shakespeare, who became the subject of Poetaster's "Virgil" (at least, as Yeats imagined the role), the "passionate dead" of "Anima Mundi":

The misfortune was for the living certainly, that must work on, perhaps in vain, to magnify the minds and hearts of our young men, and not for the dead that, heving cast off the ailing body, is now, as I believe, all passionate and flery, an heroical thing. Our Daimon is as dumb as was that of Socrates when they brought in the hemlock; and if wo opeak among ourselves, it is of the thoughts that have no savour because we cannot hear his laughter, of the work more difficult because of the strength he has taken with bim, of the astringent joy and hardness that was in all he did, and of his fame in the world. 46 
And, like the Shakespeare Yeats imagined (partly advised by his readIng of Jonson), Synge is a man who dieplays no outstanding external features of personality; like Shakespeare, Synge is, as a man, utterly opposite his muoh admired model, Jonson. In "J. K. Synge and the Ireland of his Time," Yeats writess

I cannot imagine him anxious to impress or convince in any company, or sajing more then was suffiolent to keep the talk circling. Such men have the advantage that all they write is a part of knowledge, but they are powerless before events and have often but one visible strength, the strength to reject from life and thought all that would mar their work, or deafen them in the doing of it; and only this so long as it is a passive act. 47

Both of these passages above assooiate Synge with Shakespeare-in the first instance, in the context of Jonson's praises in the second, in the kind of contrast with Jonson that Yeats makes, for instanoe, in A Vision (p. 153). But Synge's "astringent joy," "mordant humour" and the type of noble scom that makes Yeats think of Swift's epitaph are qualities both Yeats and Syngo-but especialiy Yeats at this time -would assooiate with Jonson.

[Synge] oould not have loved had he not hated, nor honoured had he not scomed; though his hatred and his scom moved him but soldom, as I think, for his whole nature was lifted up into a vision of the world, where hatred played with the Brotesque and love became an ecstatio contemplation of noble life....

...all folded up in brooding intellect, knowing nothing of new books and newspapers, reading the great masters alone; and he was but the more hated because be gave his oountry what it needed, an unmoved mind where there is a perpetual Last Day, a trumpeting, and coming up to judgment. 48

The picture we may perceive by means of Yeats's discussion of Synge 
is like a pioture of the two halves of Jonson, which are indirectly illustrated by Yeats who is plagued by oppositess the Jonson of the verse-opistle and the verse-masque versus the Jonson of Horatian satire, epigrams and the anti-masque of "Haggs, or Hitches, sustarning the persons of Imorance, Suspicion, Credulity, de. the opposites to good Fame," the Jonson not only of successful humors comedy, but also the Jonson who pitched at his enemies in the audience the coal-hot stuff of such minor plays as The Poetaster, Cynthia's Revels and The New Inn. We may perceive a resemblance between Jonson's classical erudition and Synge's attempt to follow the master's examplo. And we may especially remember the battle of the odes, which attacked and variously defended Jonson and his play, The Nex Inn, noting the parallel of The Playboy's controversial reception in the press. Synge's "hardness" and his "unmoved mind where there is a perpetual Last Day.... and coming up to judgment" may indeed resemble what Yeats felt to be the "cold implacability" of Jonson's private tribunal, which wins an audience's respect because of the superior intelleot and culture to be found in the author's finished product, the plays we are persuaded to give up our public judgment to accept the author's private or personel one, which we then take to be our own. (Such has been our "instruction.")

\section{YEATS AND THE RENAISSANCE}

It will be necessary, at this point, to fllustrate Yeats's attitude toward the period of the English Renaissance as a whole, in order to make a careful appraisal of Yeats's opinion of Jonson and 
Jonson's particular role in helping Yeats turn modern English drama "back to the paths of poetry and power" missing since the seventeenth century. Nocording to T. Modiindon in "Yeats and the Fnglish Renaissanoe, "49 it has generally been the assumption of soholars that the profound stylistic change marked by Yeats's poetry in The Green Helmet (1910) and Responsibilities (1914) was somehow significantly influenced by Yeats's sudden introduction to Castiglione's The Courtier, In 1907, by Lady Gregory, Yeats's Iriend, colleague, patroness and ideal of matronly nobility, who escorted Yeats the same year to Urbino, Ferrara, Ravenna and Florence and read to him "at the end of each day's work Castiglione's commendations and descriptions of the court of Urbino..." 50 In this dramatic way, Yeats has been pictured suddenly adopting the aristocratic perspectives that would be responsible for the anti-democratic sentiments he would express in "September 1913" and elsewhere. MoAlindon's paper, however, stresses the erroneousness of such a view. MoAlindon argues, instead, that Yeats's interest in Castiglione, though amounting to a significant sign of Yeats's further step toward the aristocratio myth of the rulIng class and his increased sense of detachment for the values of the middle-classes, was an interest developed only after Yeats had first applied himself to "a continuous study of the three greatest writers of the Inglish Renaissance," 51 a study of Shakespeare, Spenser and Jonson which had engaged him from 1901 through 1906, the year in which he expanded his study of Jonson for a projected essay and the jear in which much of Disooveries (or "my 'Thoughts and Second Thoughts'i') was written. Yeats found precedents in all three of 
these English writers for the kind of aristocratio values he wished to extol in the face of ohanging, steadily declining, modern times. Their work offered him encouraging examples of the great poets' defense of a courtly ideal, their hatred for the mob, disorder and change "at the most hesitant stage of his development as a poet." 52 They provided Yeats with insights, arguments and a style of addressing these arguments to both sympathetic and antagonistic audienoes, which would leave a noticeable impression on the poetics Yeats dramatized, at this time, in his plays. Yeats thus conceived of the alliance of poet and king, or aristocrat, in fact, as an even more necessary and vital relationship for the cultural health of a people in modern times than it had been in the turbulent past of the English Renaissance, when our modern ailments had just begun to infliot themselves upon the Pre-Raphaelite harmony Yeats felt had existed during the Middle Ages.

Generally, Yeats conceived of the period of the English Renaissance as a period of great social struggle, a period remarkable for the isolation and the high relief of its aristocracy in contrast to the decline of its common people, an historioal period somewhere well along in the process of disintegration whioh had befallen civilization since the ploughman and prince had felt themselves equally near the "sacred presenoes... of Cruachmaz or Olympus." Poets like Shakespeare, in his romantio comedies and in the sweep of his history plays; Spenser, in The Faerie Queene, the October aeclogue of The Shepherdes Calender, The Fuines of Time, The Teares of the Muses and Mother Fubberds Tale $3^{53}$ and Jonson, in the masques and satirical comedies, 
In the Great House and Great Person poems addressed to the Sidney fam$11 y$ and other great houses and personages at court, in the epigrams and in passages from the prose pensées of Discoveries, 54 shor us the highest vision of courtly achievement, of courtly ideals, while at the same time reflecting the fallen state of human affairs in reality. Yeats visualized the Engliah Renaissance, perhaps all the more for his Irish hatred for Cromwell, as a time when Puritanism, capitalism and "Individualiam" were beginning to break up the "old rhythms of life," the old agreement, for clesses of people previously sustained by the "moths of Christianity and of still older faiths,"

The courtly and saintly ideals of the Middle Ages were fading, and the practical ideals of the modern age had begun to threaten the unuseful dome of the sky Herry England was fading, and yet it was not so faded that the poets could not watoh the procession of the world with that untroubled sympathy for men as they are, as apart from all they do and seem, which is the substance of tragic irony..... The Puritanism that drove the theatres into Surrey was but part of an inexplicable movement that was trampling out the minds of all but some few thousands born to cultivated ease.

$$
\text { ("At Stratford-on-Aron," 1901) } 55
$$

Yeats's consciousness of this "inexplicable movement" antioipates Eliot's critical observation of a "dissociation of sensibility" in the literature dating from the Restoration period to the beginning of our own. But the "movement" Yeats vieualiges has more profound implications. In his ossay "Edmund Spenser" (dated 1902 in the Essays, but not published until 1906), Yeats expands his vision of this movement to include all history when he asks, "Is not all history but the coming of that conscious art which first makes articulate and then destroys the old wild eneres?"56 It was indeed, for Yeats, 
a matter of tragio irony that Spenser, who "loved his Queen....because she was the protectress of poets and an image of that old Anglo-Frenoh nation that lay amdying," had become, thorough Renalssance man that he was, an unwitting instrument in a moral and intelleotual process whioh would eventually cast up Cromwell, "The Great Demogogue," who would later, not only approve The Faerie Queene, but prooeed to carry out the sort of barbarous policies against the Irish which Spenser outlined in his View of the Present State of Ireland. 57 This "movement," Yeats believed, was perpetuated by the historical struggle between two kinds of mind, a tragic struggle in which a coarser, insistently rational and bullishly pragmatic man would gradualiy trample the finer, oarelessly illogical (but instinctively accurate), imaginative man into the earth. The struggle between antitheses, this fraoturing of the old unity into a multiple personality, Yeats saw, for instance, as the basis of the programme of Shakespeare's history plays, where Richard II and Henry V are conventionally juxtaposed, but where our conventional judgments are violated. Richard Yeats associated with Shakespeare's true sympathy, with that "old AngloFrench nation" that later "lay andying" for Spenser in the turbulent '90's. The conventional judgment, as Yeats illustrates, goes against Richard, when the charges are counter-balanoed in the following ways "Richard II, 'sentimentel,' 'weak,' 'selfish,' 'Insincere,' and Henry v, 'Shakespeare's only hero."'58 But for Yeats, Shakespeare's Henry $V$ had no real "wildness and imagination and ecoentrioity" (which are Richard's credentials, who would rather be poet than king), but "only seemed to be these things because he had some commonplace vioes. "59 
Richard, in a sense, deposes himself, negleots the state offlce ("Indeed how 11l-ftted he was to be king, at a certain moment of history") for the greater office, as Yeats thought, of poets "he was lovable and full of caprioious fancy, 'a wild oreature' as Pater bas called him." 60 Hel, on the other hand, is the Anglo-Saxon Ideal Shakespeare "held up before England" in order to make a lot of money, a "stroke of the pen" rather than a "breath of God"s he is "the rem verse of all that Richard was. He has the 8TOBs vices, the ooarse nerves, of one who is to rule among violent people..."61 Shakespeare too, like Spenser, becomes a figure of tragic irony for the extent of his perhaps unwitting contribution to this "Inexplioable movement."

Shakespeare watched. Henry $V$ not indeed as he watched the greater souls in the visionary procession, but cheerfully, as one watohes some handsome spirited horse, and he spoke his tale, as he spoke all tales, with tragic irony. 62

Shakespeare becomes, indeed, an even more visible prototype of "tragic gaiety" than Jonson in the Iast Poems, where, for instanoe, the fig ures of Hamlet and King Leer strut and rage, helpless but to say their lines and fall back behind the inevitable drop curtain of the stage in "Lapis Iazul1."

Only Jonson, of these three writers of the Bnglish Renaissance, frankly demonstrated the degree of visible antagoniam for the mob, for that vulgarity of mind that assailed the fanoy, wildness and eocentricity of the "old Angla-French nation," that Yeats felt was needed in modern times. To a remarkable extent Yeats identified with Spenser and Shake日peare, McAlindon writes; but from "no Renaissanoe 
poet," he reasons, could Yeats have more easily discovered the "aristocratic-democratic antinom" that appealed to Yeats's eristocratio outlook than from Jonson. 63 And

the deep reading done for that essay on "Jonson and the others" assisted his development into a poet who is both a praiser of life-a Naster of the Revelo-and an energetio satirist of all that is anti-life. 64

But the essential appeal of Jonson for Yeats may be best illuetrated by Yeats himself. Critics have noted-and made much of-the references to Castiglione's The Courtier appearing for the first time in Yeats's Disooveries (which itself has received little attention in regard to its possible namesake, Jonson's Timbers or, Discoveries). Later, upon his reception at the Swedish court for the Nobel Prize in 1923, his association with the court reminded him again not only of the summer nearly twenty years earlier, when Lady Gregory had taken him to Italy and read him Castiglione, but-the assooiation is immediate-of Ben Jonson, from his Preface to Crnthia's Revels, dedicateds "TO THE SPECIALL FOVNTAINE OF MANNERS: The Court."65 Yeats, in the Bounty of Sweden (1925), writes:

I had repeated to myself what I could Iemember of Ben Jonson's address to the court of his time, "Thou art a beautiful and breve spring and waterest all the noble plants of this Island. In thee the whole Kingdom dresseth itself and is ambitious to use thee as her glass. Beware then thou render men's figures truly and terch them no less to hate their deformities, than to loye their forms.... Thy servant but not slave, Ben Jonson." 66

The part of the address Yeats omits, which would have been highly improper for Yeats to repeat on this particularly ceremonious ocoesIon, is also revealing of the side of Jonson Yeats particularly ad- 
mired.

For, to grace, there should come reuerences and no man can oall that louely, which is not also venerable. It is not pould'ring, perfuming, and every day smelling of the taylor, that conuerteth to a beautiful obiects but a mind, shining through any sute, which needes no false light either of riches, or honors to helpe it. Such shalt thou find some here, euen in the raigne of CYNTHIA (a CRITES, and an ARETE.) Now, vnder thy PHABBVS, it will be thy prouince to make more: Except thou desirest to haue thy source mixe with the Spring of selfe-Ioue, and so wilt draw vpon the as welcome a discouery of thy dayes, as was then made of her nights. 67

The flattering self-portrait, as McAlindon believes, of Ben as Crites, like the court-satirist Horace (from Poetaster) who speaks those commendatory lines Yeats believed could only have been meant for Shakespeare, represents exactly the aspect of Jonson that Yeats was most attracted to: Jonson's example of a commanding Poet's reprimanding tongue and his unhesitancy to speak the full of his mind ("a mind, shining through any sute") to any audience, high or low born; the heroic audacity of the playwright to present a mock court before a real one that the real one might open its eyes to the reflection of its real self and rid itself of its new vulgarity (selflove, "false light either of riches, or honors"), that it might become again the ideal court of Cynthia or Elizabeth. Just three months before Yeats's letter to A. H. Bullen, informing his publisher of the progress on the Discoveries essays and in his Jonson studLes (which had caused him to consider writing "something on Ben Jonson, or, more likely perhaps upon the ideal of life that flitted before the imagination of Jonson and the others when they thought of the Court"), 68 Yeats was to write to Stephan Gxynn (June 13, 1906), 
telling him that "what Dublin wants is some man who knows bis own mind and has an intolerable tongue and a delight in enemies." 69 At this time, Yeats's attraction to this particular aspect of Jonson, as it has been the purpose of this chapter to show, was very much encouraged by Synge's interest in Jonson, Yeats's personal and active involvement with Irish theater in 1ts infancy and the need, generalIy, for modern English theater to receive a fundamental transfusion of energy from the heroic effort of a few great artists laboring to restore to the medium the popular roots and the strange but simple speech of the greatest literatures.

\section{THE ISLAND OF STATUES}

Just as Yeats had already some fair aquaintance with Jonson before this period, however, as the first chapter of this paper indicates, so it will be useful to trace the development of Yeats's interest in Jonson with a few specific examples from Yeats's plays which mark its progress. For this purpose, we turn to the problem imposed on us when, in his last year, Yeats announced the debt of his first known published work, The Island of Statues: An Arcadian Faery Talo-in Two Acts (1885, subsequently suppressed, in effect, by the author's refusing an authorized reprinting), which he said he owed to Jonson's unfinished last play, The Sad Shepherd. ${ }^{70}$ This early play of the "olassic-romantic" Yeats, as Patty Gurd calls him, 71 is the result of the poet's attempt to mix the styles of Shelley and Spenser "together in a pastoral play which I have now come to dislike much" ("What is 'Popular Poetry'?", 1901), a manifestation of Yeats's dream 
of the impossible life which is related to that envisioned in such early poems as "The Stolen Child," "To an Isle in the Water," and "The Lake Isle of Innisfree." The island in Yeats's play Gurd essociates with the islands of Phaodria and Acrasia, in The Faerie Queene, as well as the Garden of Adonis, where, as Gurd invokes the words of Spenser, "are fetcht all the goodly flowers wherewith dame Nature doth her beautify and decks the girlands of her Paramoures."73 Besides Spenser, Gurd sees "little touches of Shakespeare's Tempest and Midsummer Night's Dream and reminiscences of Shelley..."74 The fact that she takes no significant notice of Jonson must certainly reflect the fact that Gurd's study (1916) was completed long before Yeats published his statement (1938) associating Jonson's work with his own. But one of Gurd's minor lllustrations might well be of some profit. Focusing on the consciously archaic language of Yeats's play, we may use an example from Gurd to amplify what George Harper says is the demonstration of Yeats's early need for tradition; the need, which "led the young Yeats to search after Renaissance models," Is demonstrated by Yeats's notice of being "under the influence of The Faerie Queene and The Sad Shepherd" in The Island of Statues. 75 Gurd directs us to Yeats's lines: "The fierce kestrel birds/ Slew thee, poor sibyl" (from the variorum ed. of Plays, II, 11i, 234-5).76 "Kestrel," she writes, is an old word that she has found once only in Spenser (The Frerie Queene, II, i11, 4.4-5; "His baser brest, but in his kestrell kynd A pleasing vaine of glory he did fynd") and once in Ben Jonson's Epiooene (IV, IV, 171; "What a cast of kastrils are these, to hawk after ladies, thus?"), though Gurd misses perhaps the most 
obvious example of Jonson's humors character "KASTRIL, the Angry Boy" from the Alobemist.

"The Kestrel" is a oommon European falcon, in America generally called sparrow-hank being regarded as a mean or base kind, Kestrel was formerly of ten used as an epithet of contempt. Goblin is so particularly English, oalling up the comio grotesque figure of Robin Goodfellow, rather than that of a stately mournful faisy queen.77

(Sad Shepherd, too, has its own Puok-Hairy or Robin Goodfellow.) Perhaps if she had been encouraged by the association with Jonson that Yeats was later to make, Gurd might have grasped the connection between Yeats's early symbolio use of characters and Jonson's use of character types in humors comedy. Yeats's "queen goblin" (II, ili, 363 the Enchantress of the Irland of Statues) and Jonson's Maudin, "the Envious, the Witch of Poplewick", the counter-current of the activities of the hunters and the shepherds in the Arcady of Yeats's play and Jonson's assorted flooks of shepherds, shepherdesses (lover and love, and vice versa) and the hunters and woodsmen of Robin Hood's bower in Sherwood Forest; the Enchantress' turning of Almintor Into stone and Maudin's magic of imprisoning Aeglamour's beloved in a tree; besides the satiric remarks of Antonio, Almintor's page, as they generally resemble Jonson's comic handling of Aeglamour on the stage (the long-rinded speeches of melancholy self-flagellation followed by an exit and an immediate re-entrance with more exaggerated oaths and testaments of grief)-these are some of the possible elements Prom The Island of Statues and the Sad Shepherd, respectively, which may be usefully compared. As Dwight Eddins has observed, 78 however, the most important similarity, the similarity that leads one 
to believe that Jonson's humors oharacterization of "AFGLAMOUR, the SAD" could posaibly have served as a prototype for Yeats's Almintor, is striking in two passages from the two plays.

$\ldots$ and in one Man

As much of sadness showne, as Passion oan. The aad young Shep'ard, whom wee here present, Iike his woes Figure, darke and discontent, For his lost Iove...

(The Sed Shepherd, "Prologue," 11. 19-23)

... Iook you, sad's the murmur of the bees, Yon wind goes sadly, and the grass and trees Reply Iike moaning of imprisoned elf: The whole world's sady talking to itself. (Island of Statues, I, 1i, 9-12)

Ciroumstances of the two plays differ. For one thing, Almintor 18 a hunter, not a shepherd. But when Yeats published fragments from this play as "The Song of the Happy Shepherd" and "The Cloak, the Boat, and the Shoes," the first and third poems appearing in the Crossways (1889) section of the finally revised Collected Poems, Yeats composed a companion to the first, which is related to it in muoh the way Milton's "Il Penseroso" is related to "L'Allegro." Yeats called this second poem "The Sad Shepherd."

\section{THE KING 'S THRESHOLD}

For Yeats's ooncept of character and its relation to Jonson's well-wought creatures of humors drama, characters who frequently represent some dominating trait or idea, there will be much more to sey later. But by 1903, Yeats was producing a play, The King'a Threshold, which presents a dialeotical relation of part to part, of 
archetypes, so neatly woren on the subject of "Poesie...the habit, or the Art," as Jonson called 1t, that perhaps something should be said about it. 79 Yeats's studies of Shakespeare (1901) and Spenser (1ate 1902), as well as his work on the essay "The Philosophy of Shelley's Poetry" (1900), 80 probably had a more direct effect on the play, as a dramatic defense of poetry, than his interest in Jonson, at this time, would have had. But Yeats's arohetjpal Poet, Seanohan (like Forgael or Cuchulain, for his heroio roots in ancient Ireland), is as much, in a way, a type of the all noble poet as Volpone is a type of avarice, or as Crites and Horace are Poets nonpareil, poets of unriveled judgment and poetio powers, important oounselors to the state of Cynthia and Caesar, the court's best defenders of its virtue. The poet and those representing the best values of an aristocratic state have an alliance. As McAlindon points out from the evidence of Yeats's interpretation of Richard II, Yeats believed that "poetry and imagination are inseparable from the aristocratic." 81 "Courtly life/ Is the world's model" (King's Threshold, 11. 162-3). 82 The "inexplicable movement" that Yeats saw "trampling out the minds of all but a few thousands born to cultivated ease" during the English Renaissance, that was responsible for the tragic irony he sensed in the work of Shakespeare and Spenser, Yeats now dranatized at its mythical birth, at the ancient ejection of the Poet, the complete master of song, from the great council at the court of King Guaire.

[Ring]...I bade him go, Though at the first with kind and courteous words, But when he pleaded for the poets's right Established at the establishment of the world, I said that I was King, and that all rights 
Had their original fountain in some king,

And that it was the men who ruled the world,

And not the men who sang to it, who should sit

Where there was the most honour. If courtiers-

Biahops, Soldiers, and Nakers of the Lax-

Shouted approval; and amid that noise

Seanchan went out, and from that hour to this,

Although there is good food and drink beside him,

Has eaten nothing.

$$
\text { (11. 42-55) }
$$

Like that mythical martyrdom of Orpheus, or, more Ieataian, the death of $P$ an and the orucifixion of Christ and Cuchulain, the death of Seanchan is marked by a vision of "the worsening world," the end of the old unity of society and the birth of that dread multiple personality of class separation. Seanchan was the master of song somewhat in the tradition of the rates, ("...diviner, foreseer, or prophet ..." $3^{83}$ and his passing leaves Art divided between "the two kinds of Musios the one kind/ Being like a woman, the other like a man," one the music of "stringed instruments" sung "So artfully that all the Art's but Speech/ Delighted with its own musio," the other "carry/ The twisted horm, and understand the notes/ That lacking words escape Time's chariot..."84 Moreover, the passing of Seanchan and the mournful withdrewal of his pupils leave the court the more impoverished; for without her poets to sing her tribute there is no glory in the state. For glory, as Jonson eimilarly waras, "It is the Muse, alone, can raise to heauen" (The Forrest, XII, 4I). 85 without acoess to the higher vision of the poets' 1magination, the courtiers-"Bishops, Soldiers, and Makers of the Iaw"-must live with their orm "noise," having driven away something mysterious and vital from "the Courtly Iife" that had made it noble as "the world'a model." An exchange be- 
tween the Lord High Chamberlain and Seanchan reveals this.

Chamberlain.]... Who could imagine jou'd so take to heart

Being driven from the council? I am oertain

That you, if you will only think it over,

Will understand that it is men of law,

Leaders of the King's armies, and the 1ike,

That should sit there.

Seanchan. Somebody has deceired you,

Or maybe it was your own eyes that lied,

In making it appear that I was driven away

From the great council. You have driven away

The images of them that weave a danoe

By the four rivers in the mountain garden.

Chamberlain. You mean we have driven poetry away....

(11. 500-511)

Yeats's characterization of "the world," however, and the court that insulted its model of "Courtly life" by driving its poet from the council, is what is most relevant to our case of Yeats's growing interest in Jonson. Soon the Playboy riots of 1907 would significantly reinforce Yeats's Jonsonian hatred of the mob, increasing Yeats's disillusionment over his early "school of patriotism" to the point of disinheriting that whole class of Irish "whose attention is not given to art but to a shop, or teaching in a National School, or dispensing medicine." But for the present, Yeats's charaoterization of the various types of people represented in The King's Threshold would serve its therapeutio purpose of instruction and ridicule by delivering its medicine in suffiolently mild doses as not to lose the audience the way Jonson had, for example, in The New Inn. Wone of the types depicted really wish to see Seanchan die-not even the Soldier (who has no use for him and would make him eat "With wisps of lighted straw"), the Monk (the Church must go to ruin with the King, 
with no Poet to give them "Images" from them that "weave a dance"), the Lord High Chamberlain (who feigns himself a poet of the court), the King (to whom Seanchan's protest hunger strike is a political embarrassment), the Cripples (who wish to seize his meal) or the Mayor of Kinvara (who, out of the civic ineptitude of his type, is the chief butt of comic relief in the play). Seanchan's death comes as a heroic act of defiance for the temporal authority and as a selfsacrifice for the higher ideals that are dissolving away in the world and in the court. And such self-sacrifice is indeed anticipated, in 1892, by the Countess Cathleen's purchase of her people's soul's from the perfectly business-like Merchants of the Devil, "the Master of all merchants"; there, too, the essential bond between poet and prince, poet and aristocrat, is symbolized by the close relationship between "Aleel, a Poet," who is also gifted with visionary abilities, and the Countess, who is the epitome of such virtue that her soul will buy the thousands of her people and, in turn, will yet cause the intervention of heaven to spoil the bargain of the Merchants.

But by January, 1907, Yeats would become embroiled in a controversy which was to have, perhaps more than any other single event, a most profound effect on his subsequent vision and art. It was the Playboy rioting, the nightmare which was absurdly triggered by the word "shift," a lady's undergarment. The rioting, however, as Yeats believed, was symptomatic of a much more disturbing problem, as an account of an interview with Yeats, after the third night of rioting over Synge's Playboy of the Western World, indicates: 
Mr. Yeats...thinks 'The Playboy'

MR. SYNGE'S MASTERPIECE,

and would only disouss it inoidentally to what he called the much larger and more important question of the Freedom of the Theatre. His views on this topic are strong, and he expressod them with a good deal of vehemence. Before dealing with this aspect of the business, however, he said that the play had been attaoked on the usual grounds of which he thought the people of Dublin had got tired some years ago, and which had nothing whatever to do with art. ART, AS A FRFITCB WRITER HAD SATD, is 'exaggeration apropos'. Is Lady Nacbeth a type of the Queens of Scotland, or Falstaff of the gentlemen of England? Had these critios read 'Bartholomew Fair', by Ben Jonson, the characters in which are all either knaves or fools-are they supposed to be representative of the English people? So far as Mr. Yeats could see THE PEOPLE WHO FORMED THE OPPOSITION

HAD NO BOOKS IN THEIR HOUSES. (Freeman's Journal, Wednesday, 30 January 1907, p. 7$)^{86}$

Like the resolution of Joyce's young artist "to forge in the smithy of my soul the uncreated conscience of my race," 87 Yeats's early desire to "seal with the right image the soft wax before it began to harden" was now cast as an improbable and tragic hope straining against the inevitability of a trampling movement of history. Those middle-class Dubliners Yeats once ascribed as "vigorous and simple men" in Discoveries (1906), those shop-keepers Yeats had not wished to "elevate" or "educate," exactly, "but to make them understand my vision,"88 Yeats, some months later, began to attack openly and with a rhetorical ferocity that may be reminiscent of Jonson's evident relish for verbal combat in "To the Reader" ("an apologeticall Dialogue") from Poetaster and "Ode (To Himself)" at the end of The New Inn (also a play Yeats certainly read). 89 That Yeats's eruption of hostility had been signaled earlier, by a growth of bitterness and generalized disapproval in the essays of Discoveries and the 
dialectical presentation of argument in The King's Threshold, is ovidents music, which Yeats defines in Disooveries as the "most impersonal of things," and poetry, or the music of words (which are of all things most personal), are the two halves of unified art, or "Yhusio," which became divided in The King's Threshold; the ability to excel in either form of music, however, is not possible when the aim of the poets is such that

their temptation is not a passionate activity, but the approval of their fellows, which comes to them in full abundence only when they delight in the general thoughts that hold together a cultivated middle-class, where irresponsibilities of position and poverty are lacking. 90

Such writers may look on life deliberately, impersonally, but their ideas and speech are commonplace, as expected by their audience. And, angrily, Yeats denounced this mental slavery to commonplace, middle-class expectations, charging that "they cannot understand life if their head is not in some bag." 91 on later reflection of the Playbor scene, in "J. M. Synge and the Ireland of his Time" (1910), Yeats wrote:

...the frenzy that would have silenced [Synge'g] master-work was, like most violent things, artificial, that defence of virtue by those who have but little, which is the pomp and gallantry of journalism and its right to govern the world. ... I stood there watching, knowing well that I saw the dissolution of a school of patriotism that held sway over my youth....92

Twice in the notes of The Arrow, the official newsletter of the Abbey Theatre, Yeats carried on the Playboy battle for literary Preedom by drawing in the example of Jonson. In both cases, a counter- 
attack on the middle-class audience, its insincerity and its priggish mediocrity is evident:

No one who knows the work of our Theatre as a whole can say we have neglected the flower; but the moment a writer is forbidden to show the weed without the flower, his art loses energy and abundance. In the great days of English dramatio art the greatest English writer of comedy was free to create 'The Alchemist' and 'Volpone,' but a demand born of Puritan conviction and of bourgeois timidity and insincerity, for what many second-rate intellects thought to be noble and elevating events and characters had already at the outset of the eighteenth century ended the Kinglish drama as a complete and serious art.

$$
\text { (The Arrow, } 23 \text { February 1907) }
$$

It is to set arbitrary limits to the office of the player, to grant it gesture and facial expression, but to deny it, as some do, a fine speaking of fine things, or to think that the stage has become more really the stage, more consistent with itself, in forgetting the feeling for fine oratory that made possible the rogues and cloms of Ben Jonson and the Princes of Corneille and of Shakespeare.

(The Arrow, 1 June 1907)

Considering how often it is a matter of chance that a writer's interest in a specific figure, such as Jonson, will find its way into print, the frequency of Jonson's appearance in Yeats's writing, at this time, must demonstrate that Jonson and his work were much on Yeats's mind. Perhaps indicative of the high esteem in which Yeats held Jonson during the period of this crisis, a comparison between the first of these two passages from The Arrow, above, and the transcription Vinod Sena uses, in "Yeats on the Possibility of an English Poetic Drama," reveals a difference which may be significant sonson, as later "the greatest English writer of comedy" (which is a considerable compliment in itself), appears simply as Jonson, "the greatest writer of comedy.1195 
V. THE GREEN HELWET

As a retaliation for the nasty reception of The Playboy, Yeats immediately set to work on The Golden Helmet (1908), followed in verse by The Green Helmet and Other Poems (1910). John Rees Noore, in Masks of Iove and Death, regards this play as Yeats's attempt "to satirize the mob mentality and conduct of Synge's enemies." As Moore says,

Certainly Yeats, never democratio by temperament, had a scorn for the mob equal to Shakespeare's and Ben Jonson's, and though he hoped for larger audjences at the Abbey, he wanted them on no terms but his own.96

The Golden Helmet was first produced at the Abbey Theatre March 19, 1908. It underwent the transformation of prose to heroic coupletetaking advantage of the form such poets as Byron and Jonson have proven most suitable for satire-and was acted again at the Abbey, February 10, 1910, by very nearly the same cast, but under a new title, The Green Helmet: An Heroic Farce. At least one critic, S. B. Bushrui, in Yeats's Verse-Playss The Revisions, 1900-1910, 97 sees a similarity between the theater of Jonson and Yeats's Green Helmet. To Bushrui, the most attractive quality of the play is the Jonsonian "vitality" and "rascality" of the minor charaoters-like Laeg, Cuchulain's chariot-driver "and my master's cock of the yard"-who counterpoint the figures of authority and order, the Irish kings Cuchulain, Conall and Laegaire. Iike the grotesques in Jonson's anti-masques, these disorderly characters must be subdued, dispersed or driven out in order to restore the peece. Specifically, Bushrui 
observes,

Laeg... shares some of the mischievoumess and verbosity (not in a depreciatory sense) of some of Jonson's characters while the women characters, one of whom threatens another with

My nails in your neck and shoulder, remind us at times of Jonson's viragoes (such as Chole in The Poetaster). The wives in The Green Helmet impose their wishes on their husbands, with the exception of Cuchulgin, much as Mistress Otter [in Epiooene] rules her oaptain. 98

Yeats's great hero, Cuchulain, reminding one of that great virile Don Juan one observes in "On Those that Hated "The Playboy of the Western World,' 1907," has returned from Scotland to an Ireland breaking up by internal dissension, petty bickering and groundless fear instilled, half playfully, by the Shape-Changers, who, in this play, are symbolized by "Red Man, a Spirit" ("the Rector of this land") and the Blaok Men, dark cat-headed men who scurry in darkness to panio the Jonsonian "herd" of wives, drivers, stable boys and scullions, representatives of the deteriorating Ireland Conall calls "this unlucky country that was made when the Devil spat" (1. 48). Cuchulain strives for unity, by sharing as a drinking vessel the helmet Red Man has given the three kings to be wom by the best one of them, but the dissension increases until he must cast the helmet into the sea.

Cuchulain taking up Helmet from table]. Townland may rail at townland tili all have gone to wrack, The very strews may wrangle till they've thrown down the ataok;

The very door-posts bicker till they've pulled in the door, The very ale-jars jostle till the ale is on the floor, But this shall help no further.

He throws Helmet into the ses. (11. 245-49) 
And even then the quarreling does not cease, but rather increases to the point of violence, when, by means of deus ex machina, all is thrown in cheos and darkness and Red Man emerges from the scene, eventually, to restore order. The restoration of peace comes at the price of keeping the promise Consll and Laegaire contracted with Red Man: "Iet some man kneel dom there/ That I may cut his head off, or all shall go to wrack" (11. 260-1). Heroically Cuchulain complies: "lly fame shall spring up and laugh...[and, 7 Quick to your work, old Radish, you will fade when the cocks have crowed" (11. 267, 274). Cuchulain, however, is not put to death. The Green Helmet is fished out of the sea and placed on his head. Order is restored with the selection of the fittest king. Multiplicity, in the effect of a shared crown, must dissolve into the unity which observes superior leadership, a champion. And the laughing spirit of Cuchulain's gesture of self-sacrifioe has won that superior designation.

If The King's Threshold marks Yeats's descent into the world of reality and his taking up of action, as S. B. Bushrui and A. Norman Jeffares believe, 99 so we imagine a few of Red Man's last lines in The Green Helmet standing out with special significance as Yeats's orm active voices

Age after age I sift it, and choose for its championship The man who hits my fancy.

He places the Helmet on Cuchulain's head. And I choose the laughing Iip

That shall not turn from laughing, whatever rise or fall; The heart that grows no bitterer although betrayed by all....

$$
\text { (11. 277-80) }
$$

The king's "hand that loves to scatter," Cuchulain's joyful gesture 
In the face of death, compares favorably with the poet's gesture, the poet's joy in The King's Threshold, where

$$
\begin{aligned}
& \text {...ppotry oalls out in joy, } \\
& \text { Being the scattering hand, the bursting pod, } \\
& \text { The victims joy among the holy flame, } \\
& \text { God's laughter at the shattering of the world. }
\end{aligned}
$$

$$
\text { (11. 186-9) }
$$

All this to remind us of that aristocratic association of king (or ideal authority) and poet, and that "astringent joy" Yeats associated with the art and life of Synge after Symge's death in Narch, 1909. The rollicking rascality and boisterousmess of Yeats's characters in this "Heroic Farce" can as easily be seen as being in keeping with the spirited poetic-realism of Synge's plays as well as with en association between Yeats and Ben Jonson directly. But, then too, it has been shown already that Synge's theater owed a considerable debt to the example of Jonson. In any case, that Yeats was working, in the Green Helmet, in a manner that suggests Synge as easily as Jonson, can also be inferred from an observation by Bushrui:

The Jonsonian element makes the characters more crude and realistic. Their jealousies, their petty quarrels, their extravagance and conceit, add greatly to that quality of life Yeats so assiduously sought after; he is now more than ever concentrating on 'the roots as it were of all faculties necessary for 11 fe. 100

VI. "AN ARISTOCRATIC FORM", POUND, THE MOORE CONTROVERSY, THE PLAYER QUEEN AND "PILAYS FOR DANCERS"

Shortly after the loss of Synge early in 1909, Yeats ras introduced to Ezra Pound, who, for the next few years as Yeats's secretary 
and friend, would offer advice and encouragement to Yeats in Yeats's endeavor to simplify and solidify what he wrote by eliminating all abstraotions and needless verbiage. (Such advice, of course, three centuries of writers had at their disposal from Jonson. For instance, in Discoveries: "A strict and succinct style is that, where you can take away nothing without losse, and that losse to be manifest." And again we hear: "Our style should be like a akeine of silke, to be carried, and found by the right thred, not ravel'd, and perplex'd ..."101) It is usually assumed that the introduction to Pound was a significant event, at this time, in relation to the development of Yeats as a poet and dramatist. 102 Pound's contribution was great in introduoing Yeats to the dramatic model of the Japanese theater of the Noh. And T. R. Henn, for instance, in The Ionely Tower, is one oritio who believes that Yeats was ready by this time for another change, "that Synge's particular vein of ore had been worked out, and that the mannered rhythms were, at the end, growing monotonous and self-conscious."103 But most indications are that Pound's influence fits into a continual prooess of change in Yeats and that Yeats was not encouraged to move in a direction he was not already headed. For instance, in regard to the Noh influence, K. L. Goodwin, in The InPluence of Ezra Pound, demonstrates how, as early as 1897, Yeats "had clearly stated a theory of symbolic, non-representational drama in a letter to Fione Macleod."104 Goodwin quotes the following portions

Wy own theory of poetical or legendary drama is that it should have no realistic, or elaborate, but only a symbolic and decoretive setting. A forest, for instanoe, should be represented by-a forest pattern and not by a forest painting.... The plays might be almost, in some cases, modern mystery plays.105 
The particular play Yeats had been thinking about, as the letter rereals, was The Shadowy Waterg, the play Synge particularly objected to as "fantastic," "rarely epring-dayish" and "Cuchulainoid."106 Wothing dramatic, so far as Synge was conoerned, could frow out of its unrealistic substance. But what Yeats had in mind, in 1897, which constituted a concept of the theater indeed like that of the Nob tradition Pound introduced to Yeats in the winters of 1913, '14 and '15, was what Yeats consistently-referred to as strange, the strangeness he associated with the masques of Jonson, an association which was referred to in the preceeding ohapter. Since that first reference to the masques of Jonson in "A Poetio Drama," $26 \mathrm{JuIy} \mathrm{1891,}$ the closest comparison to make with Goodwin's example is that famillar praise of Yeats's for the staging Robert Gregory had provided his mother's play, Kincora.

Our staging of Kincora, the work of $\mathrm{Mr}$. Robert Gregory, was beautiful, with a high dignity and that strangeness which Ben Jonson thought to be a part of all excellent beauty; and all was hardly above thirty pounds.

$$
\text { (Samhain: } 1905)^{107}
$$

In support of this assertion, one might quote the sentences Goodwin leaves out of the passage from the Macleod letter:

One should design a scene which would be an accompaniment not a refleotion of the tert. This method would have the further advantage of being cheap, and altogether novel. The acting should have an equivalent distance to that of the play from common realities. 108

Similarly, when in 1914 Yeats was "not quite satisfied" with his lecture on staging, "The Theatre of Beauty" ("I held to it be- 
cause of Pound's admiration of it"), Yeats was to write Lady Gregory about a problem relating both to this aspect of strangeness, "a part of all excellent beauty" in the mesques of Jonson, and this lecture, where he had extolled the combined effects of natural lighting from Elizabethan atage architecture and simple iconological figures from the Japanese. 109 In his letter to Lady Gregory, he wrote,

I am dissatisfied with the costumes etc. of King's Threshold presented at the Abbey January 22, 23 and 24/. I am convinced that if it had been strangely and well ataged it would have roused real enthusiasm. The commonplace of it all is a discredit to it and everything shows how the figures are outlined on the back cloth. Some artist should be asked to design it all anew. It alone perhaps of my plays demands strangeness and phantasy.

(Postmark: 8 March 1914. Underscored words indicate Yeats's own italics.) 110

At this time, according to Richard Ellmann, in Yeats: The Man and the Masks, a "Iittle school of devotees of the Noh plays grew up in Iondon, including Pound, Yeats, Arthur Waley, and Edmund Dulac."11l But significantly, in another letter to Lady Gregory, we see yet again the association of this strangeness with beauty and its attachment to Yeats's work and the great examples of Renaissance comedy and tragedy 3 on April 10, 1916, Yeats wrote:

There is a chance of Ricketts, Dulac and I running a season at the Aldxych Theatre next year with Beecham. We have been asked and have sent in statement of conditions-absolute control... It may mean a fine performance of Player Queen... Iy chief object will be to get performances of Irish plays to impress Dublin. If it comes off there will be no compromise - Tomance, fine scenery, the whole Hamlet, Volpone and some Moliere plays staged strangely and beautifully.IIL

Yeats's revisions of The Golden Helmet (1908) were inconsiderable in 
Iegard to the playwright's visualization of the soene. After transforming the play into The Green Helmet (1910), the effect ras still the same as it had been: "intentionally violent and startling."113

Although Yeats developed a noticeable interest in Japanese literature from the first winter with Pound in Sussex, while Pound was working on the Fenollosa papers, Yeats was still working on a play he had started beck in 1907, the year of the Playboy riots and a year of peak interest in Ben Jonson and writers of the English Renaissance generally; the play, of course, was The Player Queen. Although Yeats's first Noh experiment was to be At the Hawk's Well, which Yeats dictated to Pound in 1916,114 The Player Queen oan be seen as an important transitional play written over a considerable period of time (1907-1922) 115 and bearing the evidence of many old enthusiasms as well as new discoveries. It was Pound, for instance, who finally suggested, after Yeats was having so much trouble writing the play as a tragedy, that the play ought to be written as a comedy. Ellmann and Goodwin point this out. 116 And obviously, even more than the symbolic use of "Intentionally violent and startling $\left[{ }^{2}\right]$ " appareled charaoters in The Green Helmet, Yeats's later use of mask and dance are given an important place in The Player Queen. But there is an aristocratic outlook implicit in the overall action of the play, as explicit in some of the individual characterizations, that strikes one as being at least as Jonsonian as Yeatsian. And not only do we find the same kind of vision that we found in The King's Threshold and The Green Helmet, that we found related to Yeats's idea of the Renaissance and the vital dependence of the isolated poet and the 
isolated aristocrat upon each other, but in The Player Queen there is a notable use of characters, once again, to move the argument (or demonstration which is the play) by virtue of their Jonsonian assignment each to some particular "manner" or "idea." The association with Jonson's concept of the humors character has been made by Peter Ure, in Yeats the Playwright. Though Ure feels Yeats's characters in this play seem awkward, like some of the matchings in Jonson's plays, he finds Yeats's characters clearly designated as "different types-one is purely a symbolic grotesque, the other is a comic humours-character."117 Yeats's vision of history, literature of the Renaissance and the work yet to be completed in modern times had been addressed in Yeats's second series of Discoveries (1908-9?), a work itself taken up with the early drafting of the Player Queen but never really finisheds

We are completing in this age a work begun in the Renaissance; we are reuniting the mind and soul and body of man to the living world outside us. Christianity revolted against the nam ture worship of the heathens, and eradually as Christianity completed itself, and especially when the paradise it set in nature's place began to fade, [it] set the mind of man apart like a pebble where nothing is reflected, a hard and abstract thing, with nature for tempter and breaker. 118

Partly Yeats's use of humor-like characters in The Player Queen was a way of visualizing the process which was about to be completed mysteriously, as Yeats belleved, in our own time. The scepter and crown change hands unbeknownst to the players on stage, for the monstrous prodigy is hidden behind a mask. But we, the real audience and players, recognize the forces, the personalities, that come to play as instruments of change; we, unlike all but the poet (Septimus), the 
prince (The Queen), the state's man (The Prime Minister), the princeimpostor (Decima) and the visionary (An 0ld Beggar), know in fact that there has been a change. And it is this typing that makes it all olear enough.

The Player Queen is a show of opposites, a spectacle, a danco almost, of antitypes. The Old Beggar, "The Oracle," fallen in a trance, brays like an ass at the completion of a oycle, the ascension of a new queen to the high office of the court (remembering that "Courtly life/ Is the world's model"), while The Bishop, whose spixitual porrers are exhausted, mistakenly denounces The Old Beggar as an impostor. The Bishop, echoing the Lord High Chamberlain's words to Seanchan in The King's Threshold, gives voice to the kind of false logic that leads to the exile of the professional man of letters (poet of the world, Septimus) and the cruoifixion of the prophet (Sidney's "vates," The 01d Beggar):

He has been accepted by the whole nation as if he were the Voice of God. As if the crom could not be settled firmly on any head without his help.

The installation of Septimus' "bad, flighty wife" in the office of The Queen, who vacates her position to be taken up in a convent ("I have long wanted to go there to lose my name and disappear"), is just the tragic movement Yeats had intended all along. But the exuberance and galoty with which the characters are now made to move the tragio plot, partly at the euggestion of Pound, compares with the Jonsonian Vitality of character-types in The Green Helmet, that heroio farce 
which champions the tragio gaiety of Cuchulain's gesture of self-saorifice.

Yeatg's attitude toward many of the types symbolizing the process of change in The Player Queen may be demonstrated, in en interesting way, by reference to an event which occurred in Yeats's life coincidental with the poet's return to writing the play. Yeats became embroiled in a bitter squabble with George Moore, one-time drar matic collaborator, now bitter enemy of Yeats and Lady Gregory. There are many colorful details to the quarrel, but the gist is that Moore had become incensed over what he considered Yeats's aristocratio pretensions and over some specific remerks Yeats had made, in a speech, in scom of the middle class. Moore had the nerve, however, to publish in his memoirs a defense of the middle class which amounted to little more than character assassination. And one of the counter-attacks by Yeats, concealed for years in a journal destined for his own Memoirg, was written while at Stone Cottage, Coleman's Hatoh, Sussex, with Pound the winter to 1913/1914, the winter in which Yeats resumed The Player Queen and in which similar poison pen speeches to the one that infuriated Moore were written. Of Moore, Yeats writes,

He takes up the common defence of the middle classes, a gibe against the critic because the critic is of them, a pretence that only the aristocracy or perhaps the working classes have a right to criticize. The word 'bourgeois' which I had used is not an aristocratic term of reproach, but, like the older 'oit' which one finds in Ben Jonson, a word of artietic usage. 'God created the nobles, God created the olerks, God created the poor, but who the devil created these people?' wrote a fourteenth-century poet. 119

Jonson, indeed, is rife with examples of "cit" in its "artistic us- 
age." Yeats's use of "bourgeois," however, means nothing if it is not "an aristocratio term of reproach." Because of the defamatory insult Jonson is able to pitch at his "citizens," of ten more obvious to the reader than to the listener, Yeats's defense is really no dofense at all, but a bitter fit of laughter caloulated to put Moore in his place. The following are examples from Jonson that may well have given Yeats this idea (upper case spellings have been added for easier location):

...your shop CITIZENS: th'are rude Animals!

And let 'hem get but ten mile out a towne, Th'out-swagger all the wapen-take.

$$
\text { (The Now Inn, IV, ii, 14-16) } 120
$$

A gentlemen of so pleasing, and ridioulous a carriage....no bred courtling, yet a most particular man, of goodly haulngs, well fashion'd hauiour, and of as hard'ned, and excellent a barke, as the most naturally-qualified amoungst them, inform'd, reform'd, and transform'd from his originall CITIICISNE, by this elixi'r, or meere magazine of man.

$$
\text { (Cynthia's Revels, V, 1v, 31-8) } 121
$$

Looke here, my sweet wife; I am mum, my deare mummia, my balsamum, my spermacete, and my very CITIE of-__...

$$
\text { (Pootester, II, i, 69-71) }
$$

CITI-SIN, quoth'al she's a wise gentlewoman ypaith, will marrie her selfe to the sinne of the CITIE.

$$
\text { (Poetaster, II, i, 122-4) }
$$

If I freely may discouer,

What would please me in my louer:

I would haue her faire, and wittie, Sauouring more of court, then CITIIE.....

$$
\text { (Poetaster, II, ii, 163-6) } 122
$$

Boddy a truth, CHITIIZENS, CHITTIZENS. Sweet Enight, as soone as euer wee are married, take mee to thy mercie out of this miserable CHITII, presently, carry mee out of the sent of New-castle Coale, and the hearing of Boe-bell, I beseech thee dome with me for God sake.

(Eagtward Ho, I, ii, 121-25) 123 
Yeats was undoubtedly attracted to this linguistic game which insistod upon combining or confusing "civitas" (OF cité), the actual root of the words "oity" and "oitizen," with "chit," a disrespectfully forward young woman (ME chitt), a baud.

If Yeats's quarrel with Moore contributes anything at all to our commentary on The Player Queen and, specifically, on Yeats's use of Jonson in constructing characters, conceptual symbols for this play, it is Yeats's treatment of the Citizens, Countrymen and The Prime Minister. Unlike the King's Threshold, where the country is more a place of refuge (where the poet has his friends to go to, like Fedelm) and the citizens are represented by the harmless, bumbling Incompetence of the Mayor of Kinvara, the Citizens and Countrymen in The Player Queen, like that "inexplioable movement" which ocoasionalIy pushes up a Cromwell, are strange, foreign creatures in their own kingdom, and they install a new, rude and democratic kind of order. The Citizens are gossipy and timid, but will gather in a frightening mob and follow, on a story they have fabricated themselves, The Bif Countryman on a witch hunt to strangle The Queen. The Prime Minister, The Queen's man, but an elected politician nevertheless ("no bred courtling"), recognizes the change as it occurs and immediately sees an advantage in the situation to advance himself to king. He has no delusions. He understands "that God or the Fiend has spoken, and that the crom is on [Decima'g] head for good" (II, 725-7), and furthermore, he understands that, at Deoima's commend, the mob would take care of any man who crossed her will ("Shouts: 'We would kill him', 'He would tear him in pieces'", II, 694-5). It is difficult to 
imagine a play which more graphically illustrates Yeats's hatred for the mob, a hatred whioh he undoubtedly shared with Jonson. "It was at the Renaissanoe," Yeats once said, "that the devil got loose, and I do not know who is going to put him back in the bottle again."124 Yeats gave up his early flirtation with the idea of discovering a epecial kind of popularity. "Iike Callimachus," it was reported, "he 'loath[ed] everything popular.""125 If, as Benn thinks, the rich ore of Synge's theater had been worked out, so far as_it concerned Yeats, then Yeats's attraotion at this time to Eastern tradition, partly influenced by Pound, was both a departure and a logical step forward in Yeats's dramatic development. The "popular poetry" and "popular beauty" he and Synge once conceived, with their vigorous language and colorful types modeled after Jonson, Moliere and Irish peasant lore, were given up to a more austere drama of ideal life, a drama which was written for the only audience for which it would matters a few well-educated and sensitive individuals who understood the difficult symbolism with which it communicated. Peter Ure, in his essay "The Plays," shows how this new direction had been signaled in Yeats's The Player Queen.

Synge had produced the perfected form of the 'peasant play', and $O^{\prime}$ Casey had brought the movement to full maturity by returning it to its megapolitical and Jonsonien centre with the one indisputable masterpiece of the whole repertoire [Juno and the Paycook]. 126

(O'Casey, who was the great protégé of Lady Gregory and heir to that school of poetic-realism perpetuated after the loss of Synge, represented the theater's movement toward objectivity, the movement oppo- 
site that subjectivity Yeats thought to be his own attraction.) As

Ure continues,

The only play which Yeats set in a city offers a startling contrast to Juno, with which it is almost exactly contemporary. Yeats had told Lady Gregory some years earlier, now that the time had come for him to leave the Abbey because the plays had turned towards objectivity, and the players had begun to copy their old grandmothers in Aran, that he sought the theatre's anti-self; and The Player Queen may be said to be the anti-self of Juno. Its two scenes... return us to the city of power; but this city is a comic emblem of a civilisation which is collapsing.

Finally, it is the aristocratic and romantic outlook of Yeats which severs Yeats's theater from the rest of the Abbey movement and distinguishes it from the aspect of Jonson's work represented by the great City Comedies.

... I have invented a form of drama, distinguished, indirect, and symbolic, and having no need of mob or Press to pay its way-an aristocratic form.

$$
\text { ("Certain Noble Plays of Japan," 1916) } 127
$$

In Yeats's commendation of the Noh, however, he is very clear about a distinction he must make for the great playwrights of the Elizabethan ages

Realism is oreated for the common people and was always their peculiar delight... The occasional humorous realism that so much heightened the emotional effect of Elizabethan tragedy ...was made at the outset to please the common citizen standIng on the mushes of the floor 3 but the great speeches were written by poets who remembered their patrons in the covered galleries.

$$
\text { ("Certain Noble Plays of Japan") } 128
$$

With the tradition of masked dancers, emblematic accessories and cus- 
tomary gestures from the Japanese theater of the Noh, Yeats expressed his wish to produce effects he had previously admired in the courtly masques of Jonson:

I saw... the mask and head-dress to be worm in a play of mine by the player who will speak the part of Cuchulain...this noble, half-Greek, half-Asiatio face... I hope to have at tained the distance from life which can make oredible strange events, elaborate words. I have written a little play that can be played in a room for so little money that forty or fifty readers of poetry can pay the price... The music, the beauty of form and voice all come to climax In pantomimic dance.

$$
\text { ("Certain Noble Plays of Japan") } 129
$$

As show in the first chapter, a comparison may be made with Jonson's thoughts and methods of achieving that spectacle of beauty that is strange by consulting certain passages of The Masque of Blacknesse, Hymenaei, and The Masque of Queenes. Important too, those "elaborate worda" compare with Yeats's first commendation of "Jonson's Masks" ("A Poetic Drama," 1891), where the masques are lauded for their "set passages of poetic oratory, and...audacious metaphors." Yeats, as he says, does not strictly imitate the Japanese. He "Invents" his owm aymbolic form of drama. And it would be surprising if this now "aristocratic form" did not owe something to what he already knew about makked entertainment from Ben Jonson and elsewhere-especially when It is realized how much the masque, with its dance, musio, oratory, entithetical movements and symbolic representations achieved through the manipulation of masks and other devices, appealed to Yeats as a metaphor of life. Stephan Orgel, in his "Introduction" to Ben Jonsons Selected Masques, writes that Jonson, after 1609 , conceived of the anti-mesque "not as a simple antithesis to the world of the revels, 
but essentially another aspect of it"; masque and anti-masque together, in the shape of the Jonson court-masque typical of this period, represent more nearly the poet's whole vision of the court, the world and the works "the masque has become for him a unified form."130 Just so, as Daniel Albright has noticed in Myth Against Mrth, 131 "the drama of human life has reduced its soale to a Commedia dell' Arte" by the time Yeats's A Vision (1925) was writtens

When I wish for some general idea which will describe the Great Wheel as an individual life I go to the Commedia dell' Arte or improvised drama of Italy. The stagemanager, or Daimon, offers his actor an inherited scenario, the Body of Fate, and a Mask or role as unlike as possible to his natural ego or Will, and leaves him to improvise through his Creative Mind the dialogue and details of the plot. He must disoover or reveal a being which only exists with extreme effort, when his muscles are... taut and all his energies active. But this is antithetical man. For primary man I go to the Commedia dell' Arte in its decline. The Will is weak and cannot create a role, and so, if it transform itself, does a after an acoepted pattern, some traditional clown or pantaloon.

$$
(\text { A Viaion })^{132}
$$

This conceptualizing or typing of characters in the drama and this oddly pseudo-scientific tagging of human personalities into ocoult Phases with emblematio names (Iike Phase 20, The Concrete ManShakespeare, Balzac, Napolean; Phase 23, The Receptive Man-Rembrandt, Synge) are obviously manifestations of Yeats's symbolio way of looking at things. This is the way he sees life, when be thinks about it; and this is the way he organizes his material when he works. Yeats's later invention of a new form of drama, an aristocratio form strongly influenced by the Japanese, modified by what he already understood about masque entertainment and adapted to Irish material, mas indeed 
have alienated Yeats from the mainstream of twentieth century theater, making it necessary for Eliot's reminder that this man Yeats had been witing poetio drama to compare with the Elizabethans quite some time before Murder in the Cathedral appeared. But for Yeats's association with Synge in the first decade of the Irish literary renaissance and their compact to recapture the rorld's attention with a drama remarkable for its integration of the whole personality, the "Intensity of personal life" partly drawn from the example of Jonson's satirical comedies, Yeats might not have been neglected by the sort of middle class theatergoer one must have to support a dramatic movement. Ironically, the dramatic legacy of Synge was to find its place in the mainstream of modern theater. But by then Yeats had withdrawn to ascend that lofty tower Jonson, before him, had removed himself to after being hoated from the stage at the presentation of The Now Inn (see "Ode (To Himself)" following the second epilogue; see also "To the Reader," 11. 222-39, after Poetaster). Though most of Yeats's theater after The Player Queen is a regression from the realism of the movement which extended from Synge to O'Casey and which joined those of Ibsen and Shaw, the return to a romantic drama of ideal life "with eostasy for its object" 133 by no means is a regression, for Yeats, to a problem which commonly inflicted itself on the romantic stage; Yeats's personal ego is not so much imposed upon a character that drama, as Synge believed, is impossible and dialogue is reduced elther to an exposition of the hero-author, or to a kind of confesaion. "Distance from life" is, above all, important for Yeats, for the deliberate artiat to create or reveal that antithetioal mask 
which, as a thing of beauty, the whole body of a play is. But that mask is not himself, not even his anti-self, even though the play, as it fits into its aristocratic form, may seem to represent that subjective identity we assign to Yeats's personality. Yeats's intention is that it is the anti-self or mask of things much Breater than his ow being, such as Ireland or Westerm Civilization in modern times. The heroic settings and heroic actions ("heroic" because they represent the "old wild energy" of past times) of Yeats's later plays must be such, because they are what the modern world is not. The Daimon-stagemanager from The Death of Cuchulain (1939), Yeats's last play, can be identified as kin to the salty old personae from Last Poems, but both escape the association we may want to make these persone, like the Old Man, should no more be thought of as the personel Daimon of Yeats than any other mask the poet or playwright chooses to make.

Character, however, as conceived by Yeats, either for the purpose of describing buman Iife (when, as in "Anime Mundi," they are "rammed with life," like the Shakespeare Jonson was believed to have described in Poetaster, or possessed by those "intellectual passions" one finds in Yeats'g Disooverles), or for depicting "ideas" or traes. on stage (ouch as Citizen, King, "Aleel, a Poet"), character is a concept Yeats had, in practice, rery much in common with Jonson. The similarity has also been noted by Rupin Desal, in Yeats's Shakespeare, 134 and by Peter Ure, in W. B. Yeats and the Shakespearean Moment. 135 Ure has associated with Jonsonian humors Teats's Iinking of Shakespeare with "the passionate dead" in "Anima Mundi." In plac- 
ing Shakespeare in such a context, Ure writes, Yeats seems to "evade the facts... to have made the mistake of confusing Jonsonian humour with Shakespearean character." As be continues,

In the Yeatsian conterts...' 'Iife' is in the depths below the naturalistic surface; reverie grants access to that world. At the archetypal level, what is powerful is so because it is generalised and shared....

Shakespeare's concern with individuality, with the unique case, has always been something of a stumbling block... The subject of (Shakespearean) dreme, [Yeats] affirms, is not man himself, but purified passion. This is really the point where Yeats attaches himself not to whet Shakespearean drame really is but to what he would like it to be-something more

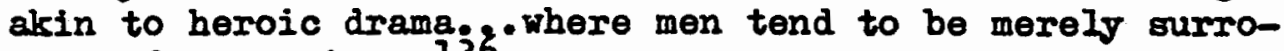
gates for passions. 136

Desai says that Yeats's concept of character, illustrated in the world masque of A Vision, seems to be close to Congreve's or Jonson's theory of humors. Interestingly, in Yeats's lecture "The Theatre of Beauty" (1911), Yeats writess

I began puzzling myself to find out what comedy had if it left the passion to tragedy, and I saw it was charecter. Then I found in a letter of Congreve's the statement that humor was that which one man had as distinguished from all other men. सumor was with him clearly the same thing as character. 137

Yeats's concept of character will be important as we examine its contribution to the development of Yeats's poetry. Those personae, which George Wright finds to be detached from the personal identities of modern poets like Eliot, Pound and post-Pre-Raphesite Yeats, in Yeats owe much to the playwright's experience, at first, with basic character types and, finally, with individual masks. The play, as concelved by Yeats, is an antithetical mask of self, the ob- 
ject the playwright has contemplated and beaten down into speeches and drections on pieces of paper. Just so, is the modern poem, as Wright observes, the "disembodied oonscioumess of the poet."138 
NOTES TO CEAPTER II

I Vinod Sena, "Yeats on the Possibility of an English Pootio Drama," Moderm Drama, Vol. IX, no. 2 (Sept., 1966), p. 195.

2 T. S. Eliot, The listener, Nov. 25, 1936, as quoted by Sena, "Yeats on the Possibility of an English Pootic Drama," p. 195.

3 Peter Ure, Yeats the Playwright (Iondon: Routledge \& Kegan Paul, Itd., 1963), p. 4 .

4 Una Ellie-Fermor, The Irish Dramatic Movement (1939; rpt. London: Methuen \& Co., Itd., 1954).

5 Ibid., p. 61.

6 George r. Wright, The Poet in the Poem; The Personae of Eliot, Yeats, and Pound (Berkeley and Los Angeles: Univ, of Califormia Press, 1960), p. 42 .

7 Ellig-Fermor, The Irigh Dramatic Movement, p. 61 .

8 Ibid.

9 W. B. Yeats, Letters of W. B. Yeats, Allan Wade, ed. (New York: Nacmillan Publishing Co., Inc., 1955), pp. 478-9.

10 T. MoAlindon, "Yeats and the English Renaissance," PMLA, LXXXII (Xay, 1967), p. 165.

11 Yeats, Letters, p. 479 , 1bid.

12 W. B. Yeats, "A Poetic Drama," Letters to the NeW Island, Horace Reynolds, ed. (Cambridge, Mass. : Harvard Univ. Prese, 1976), p. 216; originaliy printed in The Providence Sunday Journel, 26 July 1891. See also the tert of Chapter I, above, corresponding to notes 25 and 26.

13 W. B. Yeats, The Autobiography of William Butler Yeats (Ner York: Macmillan Publishing Co., Ino., 1974), p. 68.

14 John Unterecker, A Reader's Guide to Hilliam Butler Yeats (New Yorks The Noonday Press, 1959), P. 17. 
15 W. B. Yeats, Essays and Introduotions (New Yorks Collier Books, 1973), pp. 261-4.

16

Ibid., p. 263.

17

Ibid., p. 264.

18

Ibid., p. 265.

19 Ibid., p. 267.

20 Ibid., p. 278.

21 Ibid., p. 295.

22 Ibid., p. 271.

23 Ibid., p. 274 .

24 Ibid., p. 277.

25 Ibid., p. 276.

26 In the 1934 Preface to The Collected Plays of W. B. Yeats (1934; xpt. New York: Maomillan Publishing Co., Inc., 1973), Yeats writes: "In Plays and Plays and Controversies I have explained my Indebtedness to Iady Gregory. If I could have persuaded her, she would have signed The Unicomn from the Stars, her share in it is so great. She had generally some part wherever there is dialect, and of ten where there is not."

27 W. B. Yeats, "Preface to the First Edition of The Well of the Saints," Essays and Introductions, p. 298.

28

Ibid., p. 299.

29

Ibid., p. 300.

30 Douglas Duncan, "Synge and Jonson (with a parenthesis on Ronsard)," Sunshine and the Moon's Delight: A Centenary Tribute to John Millington Synge, S. B. Bushrui, ed. (New York: Barnes \& Noble Publishers, 1972), p. 205. Sources given for Corkery's and Williams' statements, respectively, are: D. Corkery, Symge and Anglo-Irish Literature (Cork: Cork Univ. Press, 1931), p. 85; Raymond Williams, 
Drama from Ibsen to Eliot (Iondon: Chatto \& Windus, 1952), p. 162.

31 Ibid., pp. 205-7, 211-16, Alan Price, Synge and Anglo-Irish Drama (1961; Ipt. New York: Russell \& Russell, 1972), pp. 13, 73, 220 J John J. Enck, Jonson and the Comic Truth (Madison, Mis.: Unir. of Wisconsin Press, 1959), P. 208, Maurice Bourgeois, John Millington Synge and the Irish Theatre (1913; rpt. New Yorki Benjamin Blom, Inc., 1965), Pp. 39-40, Peter Ure, "The Plays," An Honoured Guest, Denis Donoghue and J. R. Mulryne, eds. (Londons Edrard Arnold, Itd., 1965), p. 147; S. B. Bushrui, Yeats's Verse-Plays: The Revisions, 1900-1910 (Londons Oxford Univ. Press, 1965), P. 2083 Jonas A. Barish, Ben Jonson and the Language of Prose Comedy (Cambridge, Mass.: Harvard Univ. Press, 1967), pp. 274-5. Barish's remerks are especially illuminatings "In his programmatic effort to evolve a vital comic speech out of the raw materials of heard conversation, Jonson hence forms one of the pillars of the comic tradition. Comedy has always sought, and profited from, idiomatic language as a delight in itself. Our lenguage may be lor, we think to ourselves, but at least we can say certain thinge-chiefly scoundrelly things-never dreemed of by the poets, and say them with such rightness and pioturesqueness that they become a sort of poetry themselves... Synge's manifesto merely pleads for the resumption of such speech after the long rinter of its nineteenth-century eclipse. Realistic prose, of which Symge's folk poetry is a aubspecies, depends on the high charge of expressiveness latent in ordinary language, which in turn depends on the complex of local mores shared by the spectators."

32 Alan Price, Synge and Anglo-Irish Drama, p. 116; see also T. Malindon, "Yeats and the English Renalssance," p. 166.

33 J. M. Synge, Preface to the Poems and Tranglations, J. M. Synge's Plays, Poems and Prose, intro, Michaol Mac Liammoir ( Ipt. Iondon: Everyman's Iibrary, 1964), p. 219.

34 Duncan, "Synge and Jonson," p. 211.

35 Yeats, Letters, p. 671. Douglas Duncan, in "Synge and Jonson," p. 212, writes that Yeats, in making this statement, "was probably making no more than a retrospective guess."

36 Duncan, "Synge and Jonson," p. 212.

37 J. M. Synge, superceded draft of the Preface to The Playboy of the Western World (January, 1907), passage quoted in Duncan, "Synge and Jonson," p. 206.

38 J. M. Synge, Preface to The Tinker's Wedding, J. M. Synge's 
Plays, Poems and Prose, p. 33.

39 Algernon C. Swinburne, A Study of Ben Jonson (London: Chatto \& Windus, 1889), p. 35 .

40 Ibid.; John A. Symonds, Ben Jonson (London: Longmans, Green, and Co., 1888$),$ p. 74 .

41 Symonds, Ben Jonson, p. 72.

42 K. B. Yeats, "The Controversy over The Playboy of the Westem World," The Arrow, Feb. 23, 1907; Plays and Controversies (New York: Macmillan Publishing Co., Ino., 1924), p. 192; Uncollected Prose By W. B. Yeats, Vol. II, John P. Frayne and Colton Johnson, eds. (New Yorks Columbia Univ. Press, 1976), p. 349; Letters, pp. 612, 664-5; On the Boiler (Dublin: Cuala Press, 1939), pp. 32-3; Explorations (New Yorks Collier Books, 1973), pp. 225, 445 .

43 Yeats, Explorations, p. 445.

44 Duncan, "Synge and Jonson," p. 206.

45 J. M. Synge, Preface to The Playboy of the Western World, J. M. Synge's Plays, Poems and Prose, P. 107; see also Duncan, "Syngo and Jonson," p. 206.

46 W. B. Yeats, "Preface to the First Edition of John M. Synge's Poems and Translations," Essays and Introductions, p. 306.

47 W. B. Yeats, "J. M. Synge and the Ireland of his Time," Essays and Introductions, p. 329.

48 Yeats, "John M. Synge's Poems and Translations," Essays and Introduotions, pp. 308, 310.

49 T. MoAlindon, "Yeats and the English Renaissance," PMLA, IXXXII (May, 1967), pp. 157-69.

50 Yeats, The Autobiography, p. 368 .

51 MoAlindon; "Yeats and the English Renaissence," p. 157.

52 Ibid.

53 Ibid., p. 161. - 
54 See Ben Jonson, Disooveries in Ben Jonson, Vol. VIII, C. H. Herford and Peroy and Evelyn Simpson, eds. (Oxford: At the Clarendon Press, 1954), pp. 598-603.

55 Yeats, Essays and Introductions, pp. 106, 110.

56 Ibid., pp. $372-3$.

57 Ibid., see also MoAlindon, "Yeats and the English Renaissence," p. 161 .

58

Ibid., pp. 103-4.

59 Ibia.

60 Ibid., p. 105.

61

Ibid., p. 108.

62

Ibid., p. 109 .

63 MoAlindon, "Yeats and the English Rensissance," p. 164.

64 Ibid., p. 169.

65 Ben Jonson, Vol. IV, Herford and Simpson, eds. p. 33.

66 Yeats, The Autobiography, p. 368.

67 Ben Jonson, Vol. IV, Herford and Simpson, ods., p. 33.

68 Yeats, Letters, pp. $478-9$.

69 Ibid., p. 474.

70 W. B. Yeats, "I Became an Author," Unoollected Prose, Vol. II, p. 508; and On the Boiler, pp. 32-3.

71 Patty Gurd, The Early Poetry of Villiam Butler YestB (Lancaster, Pa.: New Era Printing Company, 1916).

72 Yeats, Essays and Introduotions, p. 3. 
73 Gurd, The Early Poetry of William Butler Yeats, p. 21.

74 Ibid.

75 George Mills Harper, "Yoats's Quest for Eden," The Dolmen Press Yeats Bentenary Papers, No. IX (1965), pp. 296-7.

76 W. B. Yeets, The Variorum Edition of the Plays of H. B. Yeets, Russell K. Alspach, od. (New York: Macmillan Publishing Co., Inc., 1966), p. 1254 .

77 Gurd, The Early Poetry of William Butler Yeats, p. 24.

78 Dright Eddins, Yeats: The Ninoteenth Centry Matrix (University, Ala. : Univ. of Alabama Press, 1971), Pp. 17-18.

79 See Peter Ure, Yeats the Plarwright, p. 29, and Peter Ure, Yeats and Anglo-Irish Literature; Critical Essays by Peter Ure, C. J. Ravson, ed. (Liverpools Univ. of Ifverpool, 1974), p. 191. The latter is also found in Peter Ure, "The Plays," An Honoured Guest, Donoghue and Mulryne, eds., p. 220. In Yeats the Playwright, vithin Ure's over all context of Yeats's "automatic lapses into Jacobean rhy thms" in Countess Cathleen, Ure makes the following observation of Yeats's craft in King's Threshold: "The King's Threshold is once more fashioned out of many units but they 'Grow, or are wrought, together', in Ben Jonson's phrase, much better."

80 Yeats, Essays and Introductions, pp. 65-95.

81 MoAlindon, "Yeats and the English Renatssance," p. 160.

82

Yests, The Variorum Edition of the Plays, p. 266. Cf. A. Norman Jeffares and A. S. Knovland, A Commentary on the Collected Plays of W. B. Yeats (Stanford: Stanford Univ. Press, 1975), p. 51.

83 See Philip Sidney, An Apology for Poetry; or, The Defense of Poesy, Geoffrey Shepherd, ed. (London: Thomas Nelson and Sons, Lta., 1965), p. 98 .

84 Yeats, The Variomum Edition of the Plays, p. 257.

85 Ben Jonson, The Forrest in Ben Jonson, Vol. VIII, Herford and Simpson, eds., p. 114.

86

Also found in James Kilroy, comp., The "Playboy" Riots 
(Dublin: Dolmen Press, 1971), p. 32.

87 James Joyoe, Portrait of the Artist as a Young Man (Ner Yorks The Viking Press, 1970), P. 253.

88 Yeats, Essays and Introductions, p. 265.

89 See Yeats, The Autobiography, pp. 217-18.

90 Yeats, Essays and Introductions, p. 278. Note the proximity of Jonson.

91 Yeats, from an interview in The Freeman's Joumal, Wednesday, 30 January 1907, reprinted by James Kilroy, comp., The "Playboy" Riots, p. 33.

92 Yeats, Essays and Introductions, p. 312.

93 H. B. Yeats, "The Controversy over The Playboy of the Westerm Norld," The Arrou, 23 February $1907 ;$ Plays and Controversies, p. $192 ;$ Explorations, p. 225; and Uncollected Prose, Vol. II, P. 349.

94 H. B. Yeats, "Notes," The Arrow, I June 1907; also Uncollected Prose, Vol. II, p. 355.

95 Vinod Sena, "Yeats on the Possibility of an English Poetic Drama," Modern Drama, Vol. IX, No. 2 (Sept., 1966), p. 200. Another differenoe is that the word "bourgeois," from the collection of Essays and Introductions, was formerly "shop-keeping." This other difference I have noted in Yeats's Plays and Controversies (1924), pp. 192-3, in the copy available to me. As this was also the reference given by Sena and I have noted no deletion of the rord "English" there, the difference noted in Sena's transoription may be due to a misprint. However, the omission may be genuine and I have no ray of knowing anything more specific, bibliographically, about Sena's source than the "P $\&$ C, pp. 192-93" noted at the ond of the passage.

96 John Rees Moore, Masks of Love and Death, Yeats as Dramatist (Ithaca and London: Corneli Univ. Press, 1971), p. 160.

97 S. B. Bushmi, Yeats's Verse-Plays: The Revisions, 1900-1910 (Iondons Oxford Univ. Press, 1965).

98 Ibide, p. 208.

99 S. B. Bushrui, "IThe King's Threshold's A Defense of Poetry," 
A Review of English Literature, IV, 3 (July, 1963), p. 83; A. Norman Jeffares, "Introduction," Eleven Plars of Hilliam Butler Yeats, 4. Norman Jeffares, ed. (New Yorks Collier Books, 1971), p. 6.

100

Bushrut, Yeats's Verse-Plays, p. 208.

101

Jonson, Disooveries in Ben Jonson, Vol. VIII, Herford and Simpson, eds., pp. 623, 624.

102 See K. I. Goodwin, The Influence of Ezra Pound (London: Oxford Univ. Press, 1966), pp. 75, 95; Richard Ellmenn, Yeatse The Man and the Masks (New Yorks E. P. Dutton \& Co., Inc., 1948), pp. 211-15; T. R. Henn, The Lonely Torrer: Studies in the Poetry of W. Be Yeats (Londons Methuen \& Co., Ita., 1950), pp. 86, 255.

103 Henn, The Lonely Tower, p. 86.

104 Goodwin, The Influence of Ezra Pound, p. 97. 105 Yeats, Letters, p. 280 , ibid.

106 J. M. Synge, from a letter to Stephan Mac Kenna, quoted by Duncan, "Synge and Jonson," p. 212. p. 181 .

107 Yeats, Plays and Controversies, p. 139 , Explorations,

108 Yeats, Letters, p. 280.

109 พ. B. Yeats, "The Theatre of Beauty; An Address Delivered before the Dramatio Club of Harvard University," Harpers Heokly, Vol. IV, No. 2864 (Nor. 11, 1911), P. 11.

110 W. B. Yeats, "Some New Letters from W. B. Yeats to Lady Gregory," Donald T. Torchiana and Glenn O'Malley, eds., A Review of Engliah Literature, Vol. IV, No. 3 (July, 1963), pp. 41-2.

111

Ellmann, Yeats: The Man and the Masks, p. 213.

112

Yeats, Letters, p. 612.

113 Yeats, The Variorum Edition of the P1ays, p. 421.

114 See Goodwin, The Influence of Ezra Pound, p. 96. 
115 Dates given are those provided by A. Norman Jeffares, "Notes," Eleven Plays of William Butler Yeats, p. 236. Jeffares writes: "Yeats began to write this play in 1907... with the intention of making a verse tragedy of it. He finighed a prose draft in 1908, and was rorking on a further prose soenario in 1909 . He continued to work on the play in 1914 and 1916. The first performance was at the King'B hall, Covent Garden, London, on 25 Hay 1919 ; the first published vergion is that of 1922." (Ce. Plays in Prose and Verse, 1922, p. 429.)

116 EIImann, Yeats: The Kan and the Masks, p. 2153 Goodrin, The Influence of Ezra Pound, p. 103.

117 Peter Ure, Yeats the Playrright, p. 135.

118 W. B. Yeats, "Discoveries: Second Series," Curtis B. Bradford, ed., The Massachusetts Review, Vol. 5 (Winter, 1964), p. 299.

119 K. B. Yeats, Memoirs, Autobiography-First Draft \& Journal, transcribed and $\theta d$. by Denis Donoghue (New York Macmillan Publiahing Co., Inc., 1972), pp. 269-70. Cf. Joseph Hone, W. B. Yeats, 18651939 (New York: St. Martin's Press, 1962), p. 2753 A. Norman Jeffares, W. B. Yoats; Man and Poet (1949; Ipt. London: Routledge \& Kegan Paul, Itd., 1966), p. 179 ; and McAlindon, "Yeats and the English Renaissance," p. 166.

120 Ben Jonson, The New Inn in Ben Jonson, Vol. VI, Herford and Simpson, eds., p. 461 .

121

Ben Jonson, Vol. IV, Herford and Simpson, eds., p. 140.

122

Ibid., pp. 222, 224, 231.

123

Ibid.. p. 534 .

124 M. M. B., "The Poet and Modern Iife," an Interviev with Yeats in The Daily News and Leader, 3 January 1913, P. 12, reprinted

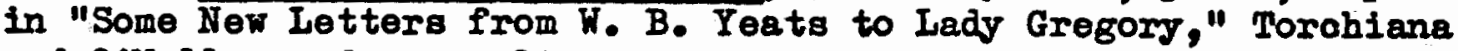
and 0 Malley, eds., p. 13.

125

Ibid., p. 12 .

126 Peter Ure, "The Plays," An Honoured Guest, Donoghue and Hulryne, eds., p. 147. 
Yeats, Essays and Introductions, p. 221.

128

Ibid., p. 227 .

129

Ibid., p. 221.

130 Stephan Orgel, "Introduction," Ben Jonson: Selected Masques, Stephan Orgel, ed. (New Haven: Yale Univ. Press, 1970), p. 13.

131 Daniel Albright, Hyth Against Myth: A Study of Yeats's Imagination in Old Age (London: Oxford Univ. Press, 1972), p. 176. pp. $83-4$.

132 H. B. Yeats, A Vision (New York: Collier Books, 1973),

133 Yeats, quoted by M. M. B., "The Poet and Modern Iife" in "Some New Letters from .. B. Yeats to Lady Gregory," Torchiana and O'Malley, eds., p. 13.

134 Rupin W. Desai, Yeats's Shakespeare (Evanstons Northwestern Univ. Press, 1971), p. 150.

135 Peter Ure, W. B. Yeats and the Shakespearean Moment; On W. B. Yeats's Attitude Towards Shakespeare as Revealed in his Critioism and in his Work for the Theatre, a lecture delivered at Queen's University, Belfast, on 27 April 1966 (Belfast: Queen's Univ., Belfast (Institute of Irish Studies), 1969), pp. 17-18, also in Yeats and Anglo-Irish Literature, p. 221.

136 Ibid.

137 Yeats, "The Theatre of Beauty," p. 11.

138 Wright, The Poet in the Poem, p. 59. 
CHAPTER III

\section{THE POEMS}

In the last ohapter, a number of important ideas rere established, elements which also had a profound effect on the poetry of Yeats. Yeats's expanded study of the English Renaissance, whioh was initiated by his interest in Shakespeare, Spenser and Jonson, and which took place significantly in the first deoade of this oentury, greatly contributed to Yeats's development of an aristocratio outlook, an essentially tragic outlook of an "inexplioable morement" of art and life moving downhill from the splendor and squalor of sixteenth- and seventeenth-century England to the modern orises of the Irish Revolution and world war. It was shown how Yeats had opposed Jonson (as "the greatest English writer of oomedy") and Jonson's great age of dramatio art to the "demand born of Puritan conviction and bourgeois timidity and insinoerity" which had "ended the Bnglish drama as a complete and serious art" in the eighteenth century. This observation-not unlike Ellot's famous observation of a "dissociation of sensibility"-was more then a consequence of Yeats's bitterness after the Playboy riots; it was observed several years earlier (recorded here in the first chapter) in Yeats's essay "What Is 'Popular Poetry'?" (1901), where Jonson's art is again posed as an attraotive altermative to the ailing art of the masses. Ieats's work for the Abbey Theatre and, later, for a selected audience which 
met in the drawing-rooms, where his "Plays for Dancers" were staged, was an essentially symbolio body of work with a substantial debt to Elizabethan drama. And Yeats's idea of character, as we have seen in those roles from the Commedia dell' Arte of A Vision, had its corresponding effect on the personae of Yeats's poetry. Heturning to the first chapter, we recall that style and personality, "deliberately adopted and therefore a makk," are not only equivalent-they are our only means of escaping "the hot-faced bargainers and the money-changers"; and expressions like this reflect the tone of Yeats's aristocratic temperament. The profound styllstic change that Yeats brought about in his poetry-all the while working out the problem of oharacter, in his plays, and personality or "life," in his oocult vision of history and being-needless to say, coincided with these other developments. In perspective, Yeats never really ceases to be romantic; but in stylo-that is, language, form and substanco-Teats ohanges quite radioally. And his portrayal of "life" or personality, the individual persone (a compounding of these matters of style into some role or Mesk, Bome representative part of Yeats's vision), was developed in a kind of poetry we recognize, for its impersonality, as modern.

In The Poet in the Poem, George Wright observes the same pattem in English Iiterature that Yeats and Eliot had noted. But Wright describes it all in terms of personae and the relative looa tion of the actual person of the poet in verse. Generally, as Wright outlines the movement from Renaissance verse to the modern verse of Eliot, Pound and Yeats, he begins with the great flowering of Renais- 
sance singers of songs, makers of beautiful things which are valued apart from their connection with their makers' selves and whioh are heodlessly passed about to delight the reader-or, as songs, the listener-just because they are beautiful, charming, emotionally or intellectually moving objects. The "I" of the poem may have some reference to the personal identity of the poet, just as it sometimes happens in the modern poem, but, more importantly, each persone is defined by its om unique habitat, a self-defining and oomplete world of language and songs though contained within some unifying tradition, each will necessarily be different from every other. But as Wright examines poetry written in the eighteenth and nineteenth centuries, he finds that poetry increasingly becomes the platform upon which the poet atages an exhibition of feelings and thoughts which pretend to be none other than his own. The "In of the poet's personal address and the "I" from even his most general poem have a tendency to be equivalent. The modern poet, however, striving to bridge this lapse of "sensibility," restores the poem to its rightful state as a thing remote from its creator. From Yeats's point of vier, the poet may glimpse or possess that Unity of Being for a moment, like the Byzantine artisan; but after the poem's magio images are passed their breath of life, the proud father must step back and let his issue speak for itself. As is pointed out at the end of the last ohapter, it is the "disembodied consciousness of the poet" that speaks in moderm verse, not the actuel person of the poet, but some character of his mind. And, just so, the modern poet re-aligns himself with the main current of literary tradition after the poets of more then 
two centuries have drifted in the shallows.

Yeats, of course, was first a romantio poets and so the moderm detachment of poet and personse we witness in such late poems as "The Statesman's Boliday," "Crazy Jane on the Mountain" and "The Wild Old Wicked Man," is achieved through a course of development which, as Wright says, is marked by a diminishing emphesis on the poet's self, "a diminished 'I." I UItimately, however, Yeats did not withhold from his poetry his personal self and his personal life to quite the extent that we notice, for instance, in the poetry of Eliots

Instead of the blurred, shadowy, withdrawn personae whose observations, selected and arranged, are an objective correlative of the poet's feeling, Yeats's "I" becomes through his poetry less and less remote, less and less withheld but it is out up into fragments, and the fragmentation is quite as stylized as the impersonality of Eliot, and in effeot just as impersonal.2

By "fragmentation," Wright means the many selves, the roles or masks of Yeats (1.0., Poet, lover, householder, father, old man, Irish publio figure, etc.). Unlike Wordsworth, whose personee most certainly represent the Poet-self (which "reacts to all events with more or less the same alertness, intelligence, and soberness" ${ }^{3}$ ), Yeats resorted to the type of romentio posing that led to the diminished "I" of Byron and the theory of masks developed by wilde. But unlike Byron, whose "'I' in Don Juan moves uncertainly between seriousness and mockery,"4 Ieats'g use of masks and the eragmentation of the "I" into the many selves of the poetmede more consistent with themselves, more preciae and impersonal the fragments which, in sum, comprised the poet's sotual self. The personae, like Yeats's concept of character (vhtoh In the last chapter was associated with Jonson's and Congreve's theo- 
ry of bumors) are as highly and individually wrought as are the poems In which they reside. In addition, Yeats achieved his modern distanoe to the romantic Poet-Hero, because Yeats's greater emphesig-after he began his work in the theater-was on the world, not the self. Otherwise, to the end, Yeats was romantlos only passionate experiences are of value, art and life must be consistently intense, heroio; and the masks or roles which are the oreations of the poet's imagination, like those romentic poses, are emblematic of what the poet aspires to be, or else are simply "the bearers of metaphorical truth." 5 But it is Yeats's special corollary to these males that gives him his modern look and his modern sounds the idealized mask cannot be presented in isolation without also presenting the "foul rag-and-bone shop" of everyday 1ife. As Wright states,

By grounding great human action in all that is most undignifyingly human, Yeats gave his conception of the noble a different and deeper turn then any ironic nineteenth-century poet dreamed of giving to his owm. 6

To thus attend upon the actual, as well as the ideal, makes the middle and late Yeats sometimes, indeed, beheve and sound like Jonson. Jonson's particular richness, his often excessive use of poetic overstatement, does not achieve the effeot of irony that Yeats can deliver by means of understatement and subtle nuance. But some of Yeats's angriest public blasts, as well as some of his finest private tributes, have been founded on Jonsonian material. (One hesitates to say that Yeats "posed" as the Jonsonian "Penshurst" poet or the indignant epigrammatist, since the occasions for these masks are rooted in the poet's genuine response to actual events. Probably, 
as we note in "Ego Dominus Tuus," the mask, alter ego or anti-self is a recourse to tradition, and Yeats's use of Jonson's language, form or material is no more than the poet's right and duty in forging a new alloy from tradition and the poet's individual imagination.) What is particularly notable, however, is the way Yeats's attention to the "rag-and-bone shop" in his poetry-a discovery from his plays-enhances and raises the image of the ideal. What Yeats discovered was that the Poet, Public Man, or whatever mask he chose to give his persona in the poem, was much more dramatically effective with respect to such surroundings; great achievement is amplified by great conflict. Yeats's use of antithesis, like Jonson's ow discovery of the anti-masque as a means to define and exaggerate the value of the court, estabilshes a great distance between "Those masterful imageg" and the "Old iron, old bones, old rags, that raving slut/ tho keeps the till" from "The Cirous Animals" Desertion"-which is, in this case, a counterpoint of youth and age. It is a development which marks Yeats's significant turn toward action and actuality, a turn which leaves the Pro-Rapheolite dream of the impossible iffe not Without discouragement, a turn from the inaction of the sad shepherd to the gay resignation of the champion who futilely but heroically greets the apocelyspe with single oombat.

Accompanying this profound ohange of vision is this profound change of style. The volce of the poet, through the bidding of his personae, becomes en active voice. His poems become more public; their form, increasingly more traditional and more public. Not surprising, considering Yeats's interest in Jonson's masques and com- 
edies and considering Yeats's use of Jonson in his essays, lectures. and letters at this time, is that Jonson also made a significant impact on Yeats as a poet.

\section{THE EARIY POEMS}

Yeats's first published works illustrate an accommodation of Jonson well in keeping with the original character and substance of Yeats's vision. The matter of Yeats's indebtedness to Jonson's The Sad Shepherd and to Shelley, Keats and Spenser, for Yeats's early Island of Statues, has been amptly discussed in two preceding chapters. But Yeats's first three of the so-called Crossways poems, dating from his affiliation with the short-lived Dublin University Review (where Yeats's "Arcadian faixy tale" was published in 1885) are also interestingly implicated in this association. According to

Russell Alspach's note, 7 Yeats's first two published poems were "Song of the Faeries" and "Voices," which appeared in the revier in March, 1885. "Song of the Faeries" was never reprinted. But "Voices" was incorporated into The Island of Statues (which appeared in April, May, June and July) and, renamed "The Cloak, the Boat, and the Shoes," was arranged to be the third poem, finally, in Collected Poems. The first poem of the Crossways division of the Collected Poems is "The Song of the Happy Shapherd"-originally "An Epilogue./ To "The Island of Statues' and 'The Seeker. ' Spoken by a Satyr, carrying a sea-shell" (1885) and "Song of the Iast Arcadian" in Oisin (1889). And alongside that poem, number two in the Collected Poems, is "The Sad Shepherd" (formerly "Miserrimus") which appeared in the Dublin University Revien for October, 1886.8 The sad and happy shepherds appear- 
Ing in these poems are traditional figures of poetry, but, like the poet who imagines their spe日ch, they seem "vague and incoherent."

Then he sang softly nigh the pearly rimg But the sad dreller by the sea-rays lone Changed all he sang to inartioulate moan.... ("The Sad Shepherd," 11. 25-7)

And they do not act. They shuffle woefully about the edge of the "dim sea" to be mocked by nature and "some twisted, echo-harbouring shell", or they turn to the grave and the dream of "old earth's dreamy jouth," "kings of the old time" and the "antique joy" of the "woods of Arcady" in the time before these things had passed away. Iike Milton's "L'Allegro," "The Song of the Happy Shepherd" renouncer melancholy or sadness, but its last Aroadian goes to his dreamy place "under the sleepy ground." Miserrimus, "the man whom Sorrow named his friend" in Yeats's "The Sad Shepherd," is really quite remarkably like his cougin "AEGIAMOUR, the Sad," the eponymous hero of Jonson's play, The Sad Shepherd: "The sad young Shep'ard, whom wee here present,/ Like his woes Figure, darke and discontent..." ("Prologue," 11. 21-2). Almintor, from The Island of Statues, was sad because of the rejeotion he has received from his beloved and is turned to stone by the enohentress of the island. But it is not apparent why Miserrimus is sad, only that he seeks oomfort for his "ancient burden" from the eoho of his own words in that "twisted, echo-harbouring shell" which joins the poem to its companion, "Song of the Happy Shepherd." The faung and satyrs of Arcady have absented themselves to their dreams and "mirthful songs" beneath the ground, like those sleepers in the tombs who begin to rattle their swords in the later 
poems of Yeats. What is left, seemingly, above ground is a picture of melanoholic sadness as traditional, as artificial and, perhaps, as exaggerated as Jonson's, where all is compounded "in one Man/ As much of sadness showne, as Passion can" ("Prologue," II. 19-20). Jonson's comic treatment of Aeglamour is readily apparent, as evident as the ironic quips of Antonio in The Island of Statues. However, even though Miserrimus is mocked, in turn, by the stars, the sea and his own words "re-echoing" (which, failing as song, are changed to an "Inarticulate moan" of forgetfulness), there is no sense in the poem that Yeats found anything but sympathy in his heart for this lone figure on Time's "humming sands." The rough comedy of the contest in The Island of Statues between the happy and sad shepherds (Thermot and Colin) is lost to the poems, where the happy shepherds, in renouncing sadness, renounce the world; the inward turn of the last Arcadian to his grave and dream is necessarily sad to us for the joy it absents from the rorld.

In the earliest Yeats, therefore, we typically find two types of singer portrayed in the poems. Resorting to the pastoral landscapes of Spenser-and Jonson, in the rare case of The Sad Shepherdthese singers or shepherds are charecteristically happy (and heve removed themselves from the vieible world) or sad (because the lost Arcadie, where the "shouting days with mirth were crowned," is ropleced by the vacuous echoing of whispered words-eenseless, disjointed "moans" rather than the potent Truth of past times).

Hords alone are certain good.

The Wandering earth herself may be 
Only a sudden flaming word,

In changing space a moment heard,

Troubling the endless reverie.

("Song of the Happy Shapherd," 11. 10, 18-21)

Thus Yeats expresses his belief in the power of words. But the words he chooses, the saccharine words and twilight images of the PreRaphaelite Yeats, deny the full scope of that power. The poet faces the dream of the lost Arcadia and the impossible life, the eternal. His metaphysical inquiries and his studies of Blake had convinced him that a reality more substantial than "this vegetable universe" indeed existed which was more valuable of our time. But Yeats does not turn about and face the world of actuality until be tires of that style which made him conventional as a Pre-Raphaelite. Again and again the young Yeats entertained that dream of the ideal life in his attempt to escape actuality; and examples of this are easily obtained; "The Lake Isle of Innisfree" is one; "To an Isle in the Water" is another; "The Stolen Child," The Island of Statues and, perhaps, The Wanderings of Oisin are others. Furthermore, George Wright observes that

Yeats himself, when he enters the early poems, is usually cast as a poet or lover, wi thout flaws; he is unidentified, unlocated in time and place. He is poor, he dreams, drinks ale, weaves songs, has moods, loves, and is sad; but in all this, nothing differentiates him from the hordes of passionate young men of his time who also do these things. Essentially, he does not ect, and his communion with the eternal, like the communion of his legendary persones, is the consequence not of his moral choice but of his occupation.9

It would later be possible for Yeats to writes

... In some of my lyric verse... there is an exaggeration of sentiment and sentimental beauty uhich I have come to think unman $18 . . .$. I have been fighting the prevailing decadence for 
years, and have just got it under foot in my own heart-it is sentiment and sentimental sadness, a womanish introspeotion..... I cannot probably be quite just to any poetry that speaks to me with the sweet insinuating feminine volce of the drellers in that country of shadors and hollor images. I have dwelt there too long not to dread all that comes out of it.

(Letter to AE, 1904)10

But this would not occur until Yeats had begun to supply his poems with something of that "rag-and-bone shop" of common reality (particularity and living speech), until he had begun to introduce, as Wright calls it, "the trivial quotidian personality out of which the mask grows and in relevance to which the mask is significant achievement." 11

\section{IN TRANSITION, THE EMERGENCE OF THE HERO}

By 1900, the language of Yeats's poetry begins to ohange, perceptibly, as a result of his contact with the public while producing some of his first plays. His contact with a physical audience gave him the opportunity of finding out first-hand what people liked and didn't like, and it gave him the opportunity of experimenting in fields virtually unknow to him before; in comedy, for instance, in collaboration with Lady Gregory and in his close relationship with Synge, he wrote clever country farces in Irish peasant dialect, then very popular in Dublin. It was Yeats's wish at that time for popular1ty, a "popular theatre" and the achievement of a "popular beauty" (discussed at length in the last chapter), that got Yeats moving as a publio man-aside from his political activity with o'leary. For he wished to please as much as he wished to improve the character of his audience-acting as an artist of life, not just of the dream-by recasting it in the Ilkeness of some heroic mask, preferably one dram 
out of the Celtic pest, like Cuchulain. And this would have succeeded, except by temperament both Yeats and Synge were attracted to means and matters of expression which the popular audiences of Dublin found offensive. Both felt the ne日d for a living spe日ch similar in charaoter to the Jacobean English of some of Jonson's city comedies, such as Bartholomew Fair, The Alchemist, Volpone and Epicoene. The wildness and caprioious fancy that led simple Irish folk from lighthearted gaiety, one moment, umpredictably to some passionate, violent act, the next instant, came to be represented, naturally enough, by the west-Irish dialect studied by Synge, Iady Gregory and, to a lesser extent, Yeats. However, like Jonson, Yeats and Synge had purposes beyond mere entertainment for their use of showy speech. And consequently the battle for the literary right to exeroise that gaiety and that violence on the Dublin stage, with the freedom Ben Jonson was thought to have had in James's Iondon, became an issue that leats took to the press and to the circulars of the Abbey Theatre. Though born with the idea of achieving a new kind of popularity, such as was believed to have been possessed by the ancient Greek drematists, the simplified style which ras used in the theater was carried to the poems, where an awakening to this world of action and controvergy was also taking place.

Also significant at this time was Yeats's development of a socially aristocratic outlook and an artistically tragio vision which combined with one another to provide the poet, now an active man of the world, both an exemplum with which to oppose the multitude and an escape from the "foul ditch" of common life. Yeats's notice of an 
"inexplicable movement" in "At Stratford-on-Avon" (1901), only partIy represented historically by the "Puritenism that drove the theatres into Surrey... [end] that was trampling out the minds of all but some few thousands born to oultivated ease,"12 was similarly interpreted as the "foul tide" which had engulfed the life of Spenser. In his essay "Edmund Spenser" (1902), Yeats connected the character of a poet's personality to the character of living verse-in this case, reporting the humors which were believed to have been responsible for behavioral characteristics in Elizabethan psychology-rhich Yeats observed to be involved in this movement of the "worsening worlas"

Old writers gave men four temperaments, and they gave the sanguineous temperament to men of active life, and it is precisely the sanguineous temperament that is fading out of poetry and most obviously out of what is most subtle and living in poetry-its pulse and breath, its rhythm.... Every generation has more and more loosened the rhythm, more and more broken up and disorganised, for the sake of subtlety of detail, those great rhythms which move, as it were, in masses of sound. 13

Yeats's view of actuality becomes more and more the vision of apocalypse that we have in "The Second Coming." But it is the poet's condition to live in the world of actuality; and so, faced with this prospect of total ruin-and indeed, for Yeats, it is fated-he greets this fate with the self-possession and abandonment of a hero. His reward is the joy of the gesture, the escape his free mind has achieved from the mean and the trivial.

That we may be free from all the rest, sullen anger, solemn virtue, caloulating anxiety, gloomy suspicion, prevaricating hope, we should be reborn in gaiety. Because there is sub- 
mission in a pure sorrow, we should sorrow alone over what is greater than ourselves, nor too soon admit that greatness, but all that is less than we are stir us to some joy, for pure joy masters and impregnates; and so to rorld end, strength shall

laugh and wisdom moum.

$$
\text { ("Pootry and Tradition," 1907) } 14
$$

This "tragic gaiety" of Yeats's heroes is usually attributed to Yeats's reading of Nietzsche. 15 But, however that may be, the qualities that Yeats admired most in his heroes-whether they be O'Ieary, Parnell or - Ben Jonson as Reveler at Court and critic at large-were essentially aristocratic; for, as Ieats writes,

In life courtesy and self-possession, and in the arts style; are the sensible impressions of the free mind, for both arise out of a deliberate shaping of all things, and from never being swept away, whatever the emotion, into confusion or dullness. ("Poetry and Tradition") 16

What is aristocratic in life (i.e., "courtesy and self-possession") is the character, achieved through style, that Yeats demanded of great art:

...a writer, who has to withdraw so much of his thought out of his life that he may learn his oraft,... should never be without style, which is but high breөding in words and in argument. He is indeed the creator of the standards of manners in their subtlety, for be alone can know the ancient records and be like some mystic courtier who has stolen the keys from the girdle of Time, and can wander rhere it pleases him amid the splendours of ancient Courts... He has at all times the freedom of the rell-bred, and being bred to the teot of words can take what theme he pleases, unlike the linen-drapers, who are rightly compelled to be very strict in their conversation. Who should be free if be were not? for none other has a continual deliberate self-delighting happiness...

("Poetry and Tradition") 17

The "sanguineous temperament". of the heroio poet, who tragioelly faces the "rag-and-bone shop" world of actuality which is 
about to be destroyed, impels the poet to behave in a manner much like Jonson. To those beloved and respected, Yeats writes the kind of courteous and noble tribute that is the distinotive mark of Jonson's odes, elegies and epistles in The Forrest. Yeats's tribute to the "well-bred" living and their dead, to the house of Gregory and the "old fathers" of his own ancestry, is a monument to them, but is also an expression of mourning for the excellence that is passing out of the world; as he says, "we...sorrow alone over what is greater than ourselves"; risdom mourns. But, like that strength and selfpossession we sense elsewhere in Jonson's epigrams and satirical verse, Yeats's poetic defense of aristocratic values-his own and the values of those whom he loves-is carried out with a power and self-delighting wit (much at the expense of the "knareg" and "dolts" who populate the opposition or mob) that is without precedent in the early Yeats. ("...all that is less than we are stir us to some joy, for pure joy masters and impregnates; and so to world end, strength shall laugh...") The "sanguineous temperament" of the heroic poet, who actively faces the world (in A Vision, later celled the "Body of Fate"), leada ultimately to the expression of "tragic joy"-like Seanchan from The King's Threshold, who announces that poetry is "God's laughter at the shattering of the world" (1. 189).

"Mragio joy," an action, a stylish gesture, the "scattering hand" of God, the champion or the gambler, in Yeats represents the old aristocratic sprezzatura. B. Rajen points out, in "Yeats and the Renaissance, "18 that in Hoby's translation of The Courtier, for instance, gprezzatura is rendered the same as "recklessness"; and he 
believes that this perhaps led Yeats to become "carried away" with his own interpretation. But Charles Altieri, in "From a Comic to a Tragic Sense of Language in Yeats's Mature Poetry, "19 defines Yeats's poetic demonstration of "the aristocratio ldeal of sprezzature" as the "natural mastery over one's situation achieved through 'self-possession and power.'" Altieri's assessment seems to be more satiafactory than Rajan's, because it is broader and more sensitive. It explains both the recklessmess, the ease with which the laughing Cuchulain is willing to cast away his own life in Yeats's play, The Green Helmet, and it explains Yeats's renewed interest in such poets of poetic energy as Byron and Jonson, figures that Yeats frequently praised in his correspondence and lectures between 1903 and 1910, as John Unterecker points out in A Reader's Guide to Hilliam Butler Yeats. 20

But as much as we might think, there is no distinct break between the early romantic Yeats and the later poet of action. Even though a vigorous new style had definitely arrived by Responsibilities (1913-14), certain of these poems have a history dating back to the previous collection, The Green Helmet and Other Poems (1910 and 1912), which, in turn, is not unrelated to things which were beginning to happen in the volume before that, In the Seven Wooda (190304), and so on. For practical purposes, however, our examination need reach no further back than the latter collection. For, as Denis Donoghue, in William Butler Yeats, writes?

...beginning with In the Seven Woods, Yeats's poetry admits into the otherwise self-enclosed garden of ert the lives of other people-rarely ordinary people, I conoede, but suffioiently common to acknowledge a reality that cannot be dis- 
solved. These 'presenoes' are palpable, and they correspond to the vernacular idiom of the poems they inhabit. The result is that the professed symbolist is often, in practice, hardly a Symbolist at alls the student of Nellarmé resorts to Jonson and Donne. Style in these poems is a testament to values still persiating in the finite rorld, and it encourages Yeats to meditate between his rival dreams, Innisfree and apooalypse.21

In the volume In the Seven Woods, as Wright also notioes, 22 Yeats begins to make his personae-the beloved, for instance-more partioular, more actual. In "The Folly of Being Comforted," the "wellbeloved's hair has threads of grey..." (we are stepping outside the dream world of eternity) ".../ And little shadows come about her eyes." We still have a heavy regidue of "poetic" language; but the personae of the lover ("I"), the friend ("One that is ever kind") and the "wellbeloved" are beginning to emerge from the shadows to become more actually the likenesses of Yeats, Lady Gregory (probably) and Maude Gonne, respectively. Furthermore, the bitterness and ironic treatment of the beloved, which colncides with Yeats's first real attempt to rid himself of the "exaggeration of sentiment and sentimental beauty which I have come to think unmanly... a womanish introspection," marks this collection as something of a mid-point in his development of a new style. Interestingly, Muriel Bradbrook, in "Yeats and Elizabethan Iove Poetry," suggests that

the development of Yeats... follows the same course as the development of Elizabethan love poetry in the earlier time; first a high Petrarchan idealism, leading to a sharp and bitter poetry, which includes many of the seme negative emotions as Jacobean lyric, or drama.23 
Midway between the Petrarchen idealism of the lover in the 1899 Wind Among the Reeds and the Jacobean "negative emotions" demonatrated by such poems from The Green Helmet as "Words," "No Second Troy" and "Reconciliation," we have the poems of In the Seven Woods; and, for our purposes, that collection is best represented by the single poem "Adam's Curse." The narrative fourth and fifth stanzes of that poem are still in the language of the Pre-Raphaelites; but the lushness is restrained and controlled; and the first three stanzas of dialogue give us something of the sense of a live drame, because their language is roughly that of ordinary conversation (though one is not actually likely to say such things as: "To be born woman...," "....no fine thing/ Since Adam's fall but needs much labouring," and "That they would sigh and quote with learned looks"). The English is still bookishly stylized; but Yeats is beginning to effectively introduce the common speech of the "rag-and-bone shop." The speech of the Anglo-Saxon is opposed to and, consequently, meant to show off the Anglo-French style of that "old high way of love," the expression of which is now restrained and controlled. And the dramatic situation presented in the poem-three prople sitting together, two of whom speak; "I" who is a poet, "you" whose beauty is waning, and "That beautiful mild woman, your friend"-is made to seem more realistio for us by this contrast of styles. The poet in the poem makes his point with a great deal of energy, it would seem, as he says to the "beautiful mild womang"

$$
\text { ...'A line will take us hours maybe; }
$$

Yet if it does not seem a moment's thought, our stitching and unstitching has been naught. 
Better to go down upon your marrow-bones And scrub a kitchen pavement, or break atones Iike an old pauper, in all kinds of weather; For to work harder than all these, and yet Be thought an idler by the noisy set Of bankers, schoolmasters, and clergymen The martyrs call the world."

("Adam's Curse," 11. 4-14)

The "noisy set/ of bankers, schoolmasters, and clergymen" remind us of those archetypal enemies of the Poet and the Court from The King's Threshold, an exact contemporary of this 1904 collection. They also remind us of those keepers of the till of later poetrys and they represent whet "The martyrs call the world." But another importent contemporary was Yeats's "rarely spring-dayish" and "Cuchulainoid" (Synge's words) The Shadowy Haters, first produced in 1904. "In the Seven Foods" (dated August, 1902), the introductory poem to the volume of verse bearing its name, is partly derived from the prologue of the published version of Shadowy Waters, "I walked the seven woods of Coole" (September, 1900). Our chief interest in the play here, however, is the entrance of love and beauty into Yeats's conception of "tragio joy." Love and beauty, which are Platonically related, are, as such, the central focus of "Adam's Curse." In the play, dream and reality are opposed; and the dreem (the land of the Everliving) is the souroe of our passion and our love. The poet's searoh for a "changeless love" is fruitless in this world of actuality which is only a flickering shadow of the etermity to which it is opposed. Our joy is also our grief: because it is "all deceit, and flattery/ To win a woman in her own despite,/... Love is war, and there is hatred in it" (11. 393-5). In "Adam's Curse," Yeats acieves a dou- 
ble effect in the portrayal of his poet persona, because of this belief. The poet, as graphically as he can imagine saying, describos the poet's plight of laboring for beauty, "to articulate sweet sounds together." (The "Curse" in the title is God's curse on Adam, when he was driven from the garden and made to earn his bread by the sweat of his brow.) The "beautiful mild woman" ("...for whose sake/ There's many a one shall find out all heartache"; 11. 16-17) makes this rather over-talkative poet's claim for poetio labor seem ridiculous with her terse remark: "To be born women is to know-/ Although they do not talk of it at school-/ That we must labour to be beautiful '" (11. 19-21). The remark has its telling effect, for the conversam tion quickly ends after the poet's short ironic flourish about mistaken lovers who have tried to follow "Precedents out of beautiful old books/...an idle trade enough" (11. 27-8). The last two ruminative stanzas undersoore the irony by establishing the poet and his silent beloved as two such mistaken lovers. The poet doubtlessly believes in the dream; but the dream is subject to the interference of reality, where courtship is reduced from "high courtesy" to "deceit, and flattery/ To win a woman in her own despite," and where a noman's "labour to be beautiful" amounts to the same as that "bought Art" of cosmetology which Jonson lampooned, for instance, in "An Epigram. To the small Poxe." 24 By so closely associating such worldilness with "the noisy set/ of bankers, schoolmasters, and clergymen," Yeats invites, as Wright believes, a "double judgment" of the persone which is Yeats's representation of himself as poet and lover. We are to conolude: "first, that he is to be mocked for his pretensions; 
and, second, that he is to be admired for his aspiration."25 The lovers have "grow/ As weary-hearted as that hollow moon" (11. 38 9). But the poet-which is as much as to say, Yeats-is not to be blamed. His grief is to be borne with his love-though both are beginning to appear in the past tense.

\section{THE GREEN HELMET}

Bitterness is evident in all but a few of the poems of In the Seven Woods. And, while Yeats himself is beginning to appear more and more openly in the poems, like Jonson's self-mocking appearanoe In the comic romanoe of "A Celebration of CHARIS in Ten Iuriok Peeces"-where, from the beginning, we have the picture of the actual man, his bulky flesh, fifty years, pock-marked face, eto.-Yeats, in his "negative" Irony and his "Jecobean" bitterness, did not produce that Jonsonian spirit of humor in a collected body of verse until the first appearance of The Green Helmet and Other Poems in 1910. Meanwhile, Yeats had plunged deeply into that study of Jonson which has been discussed in the past chapters.

In The Green Helmet, we observe the birth in Yeats of humorous satire and his use of the epigram. Not only does Yeats place these poems in the world of actuality, where the persona of the poet is often particularly based on Yeats himself, but, in form and theme, the poems are more public and traditional than past verse. William York Tindall, in "W. B. Yeats," makes a similar observation. Aocordingly, be writes that

the characteristic verses... are satiric epigrams, occasional 
in theme and classical in deportment... The dogs, fleas, and eunuchs of these bitter things would not have pleased young Yeats. Instead of Shelley now, or Morris, he turned for models to Iandor, Ben Jonson, and Cheucer.26

Similarly, William M. Carpenter, in "The Green Helmet Poems and Yeats's Myth of the Renaissance," stresses the influence of Yeats's reading of "Ben Jonson and the others," mentioned in Yeats's September, 1906 letter to Bullen, on the profound stylistic change to be noted in these poems. As Carpenter notes,

The title and opening lines of 'King and No King' refer to the Beaumont and Fletcher play and reflect the considerable reading of Renaissance drama Yeats did in this decade 1900 107. The four-line epigrams are Jonsonian in both attitude and form, especielly 'To a Poet, who would have me Praise certain Bad Poets, Imitators of His and Mine.'27

"An influence," as Tindall defines it, "is what a man is ready for."28 To a considerable extent, a biographical perspective of Yeats's attraction to the material and style of Jonson's plays has been rendered in the two previous chapters, which discussed his reading, his essays, his correspondence, and his plays. But two further matters should be taken up at this points first, Yeats's interest in the non-dramatic verse of Jonson; and second, the dramatic change in Yeats's personality which coincided with this interest and which, among other influences at the time, was linked to his study of "Jonson and the others," the controversy over literary freedom of the stage and the appearence of Yeats's Collected Work in 1908. His interest in Jonson's poetry is substantiated by T. MaAlindon, so far the chief writer on Yeats's Jonson, in "Yeats and the English Renaissance," 29 and J. G. Nichols, in his "Jonson and Yeats" 
appendix to The Poetry of Ben Jonson. 30 Adding to these Yeats's casual reference to The Under-rood, in Samhain: 1901,31 and the additional notices given to Jonson's poetry by the meng sources later used in this paper, it seems highly likely that, when Mrs. Yeats was reported to have said that Jonson was "'not one of Yeats's gods', but he read and admired him greatly," 32 she meant the poems as well as the plays and masques which were already well-known enthusiasms of Yeats's.

To fulfill the second purpose, which is to show the change in Yeats's personallty which accompanied his interest in Jonson, we need to consider several important events which took plaoe in Yeats's Iife while the Green Helmet volume was being written. To name one, Maude Gonne's refusal of Yeats's proposal of marriage was followed, in 1903, by the insult of her marriage to John MacBride, a "drunken, vainglorious lout" in "Easter 1916"; this subject is bitterly pubIished, in The Green Helmet, in "Words," "No Second Troy" and "Roconciliation." Later, the dream of a "popular theatre" in Ireland, which could compare with the humor and life of the great plays of Jonson and Moliere, ras vanquished by the Playboy riots of 1907, in answer to which Yeats wrote his satiric farce, The Green Helmet; and published with this play, in 1910 and 1912, were these poems whose typical character is represented by such epigrams as: "On Hearing that the Students of our New University Have Joined the Agitation Against Immoral Iiterature" and "The Attack on the "Play Boy" (later famous as "On Those that Hated "The Playboy of the Western World, ' 1907," in Responsibilities). Yeats was, of course, also 
shocked by the death of Synge early in 1909. But, while distressed over these three other events, there was yet another matter that made a significant impression on the poets the publication of the first complete edition of his work. An examination of Yeats's correspondence with A. H. Bullen, Elizabethan scholar and editor of the Shakespeare Head Press, raises more than Yeats's report of being "deep in Ben Jonson" while working on the piscoveries essays, published serially as "Thoughts and Second Thoughts" (1906). As Frank C. Nelick reports in "Yeats, Bullen, and the Irish Drama," 33 by means of the various details of publishing arrangements, drafts, proofs, and the like to be found in the Yeats-Bullen letters of the O'Hegarty collection, we can trace the very trying history of Collected Horks (1908), one of Yeats's most serious concerns from the time he first suggested the project, on June 22, 1905, to its completion. This suggestion, on the part of not just a living but a relatively young artist-forty years of age, twenty years in print, with nearly thirty-five years of life and by far his most important work still ahead of him-resembles Jonson's audacity when, in 1616, the latter published his carefully supervised Horks in folio. Moreover, Yeats was greatly concerned with getting the "most definitive and impressive public exposure for his work." 34 His great concern was cause for his sister Elizabeth, an editor of the Dun Emer Press, to complain that he had become

extremely difficult to work with and was late with his assignments. Dominated by Lady Gregory's Judgment... he had thoughtlessly made enemies in Ireland and... was not writing Iyric poetry as he should have been. Ireland expected more of the so-called Celtic Trilight. 35 
The essays, which Elizabeth's press had published the previous year as Discoveries (1907), do indeed show the effect of "Lady Gregory's judgment" (she functioned as something of a secretary for him as he wrote them, and was responsible for his introduction to Castiglione), as they do indeed also reflect his study of Jonson, which took place at the same time. The publication of the Collected Works (eppearing "delicately handsome in quarter-vellum back and grey linen sides") was of deep significance to the poet. After its completion, Yeats could sit back and take matters differently. As Nelick writes:

the revisionist still appears, but, no longer tentative and worried, he is, more often than not, imperious. The Shakespeare Head edition was a crisis in Yeats's life, and once tbrough it he was a different man. 36

Iike the models he now took for his art, the new Yeats was confident, assured, aristocratic, contemptuous of those who offend and are offended by quality. His use of Jonson in Discoveries, which Yeats wrote in that tentative, exploratory manner common to the ramblings of Jonson's critioisw, made way for that new confidence through this period of adjustment. References in these essays to Poetaster, Cynthis's Revels and Epicoene, McAlindon reports, suggest that Yeats was interested in Jonson "as a type of premodern poet whose vigorous comic art proceeded from a contemptuous indifference to mere logic and general approval." 37

Reflecting this change of attitude, in The Green Helmet poems of 1910 and 1912 Yeats produced a fit imitation of Jonson's example. From this time forward, scholars invariably recognize a new Yeats. As I. C. Knights records, in "Poetry and Social Criticism: The Work 
of $\mathrm{T}$. B. Yeats,"

From the time of The Green Helmet (1912) onwards he protested emphatically and continuously against democratic vulgarity...., middle-class caution..., and ready-made nerspaper notions and sentiments; against violenoe of opinion...issuing in physical violence and cruelty...; against, in short, the related symptoms of a social, political and cultural disintegration summed up in... The Second Coming (1921). 38

But more specifically, the profound change in the poet shows up in the poetry as a profound change in style. In summarizing Yeats's often rather hot Jonsonian air in the poems of the Green Helmet and Responsibilities period, T. MoAlindon claims that

No English poet, not even Landor, approximates so closely as Jonson does to the egotistical, arrogant satirist who aligns himself with the aristocracy and associates his enemies with the mob in The Green Helmet and Responsibilities. Anger and distrust, contempt for the many and admiration for the fewentirely new material for Yeats-form the basis of the finest poems in these tro volumes. (The victims of Yeats's irony and scorn are similar to those appearing in Jonson's Poetaster and Cynthia's Revels: They fall into the perennial Jonsonian categories of 'knave' and 'dolt'... Iike the wretohes who annoy [Jonson's] Horace [in The Poetester] ... they are conceived as a collection of insects and animals.... They undervalue the poet. 39

Indeed, it sometimes happens that the general discussions of these two collections, by being addressed more or 188 s to both at once, encourage a somewhat blurred picture of the sequence of Yeats's interests as they occurred in time. For instance, noting the emerging new style of Yeats in "The Green Helnet' and 'Responsibilities," T. R. Henn writes:

There are exercises in a Jonsonian compression of the epigram. Checks and hypermetrical syllables are slowly becoming integrated into something that can approach speech-rhythms. There is 
a use of homely even brutal idiom, that I connect with Synge's demand for a poetry that should have its 'strong roots among the clay and the worms'.40

These are valuable observations; and they seem generally aimed at both collections of verse. But the context of these statementsYeats's first association with Pound, his "likely...rereading of Ben Jonson," his "reading of Dante and More" and his discovery of Donne through Sir Herbert Grierson-focuses our attention on the year 1912 and may, therefore, be misleading, since it was by then probably too late to influence the Iyrics of The Green Helmet, either the Cuala (1910) or the Macmillan (1912) editions. One supposes that by a "rereading of Jonson" it is meant that Yeats was again in contact with Jonson's work after his expansive study in 1906; but it is not certain that Yeats at this time was ever far out of touch with Jonson, considering his shared enthusiasm with Synge and his use of humore-like characters in the Green Helmet play. Besides that, clearly Pound's influence had little or no effect on the poems of The Green Helmet; for, as K. I. Goodwin in The Influence of Ezra Pound writes, "Yeats's second period began quite independently of Pound.... Statements made by Pound in 1914 add support to the suggestion that he had little to do with Yeats's poetry until then."4l Furthermore, Yeats had read Donne long before he had received his gift copy from Grierson of the Poetical Works; and elsewhere Henn himself refers to the note of thanks Grierson received from Yeatss "I...find," Yeats wrote, "that I can at last understand Donne.... Poems that I could not understand or could but vaguely understand 
are now olear..." 42 Such general discussions are valuable-as this one by Henn undoubtedly is-but require cautious consideration from the student. Another such discussion by Colin Meir, in Ballads and Songs of W. B. Yeats, bounds back and forth in time thematicallya hazardous business in Yeats-but successfully illustrates Yeats's adaptation of what he called "the passionate syntax, the impression of the man who speaks, the active man, no abstract poet."43 As Meir shows, Yeats's rediscovery of Ben Jonson, Byron, Donne and Burns in this period-poets who represent a "tradition of poetry that deals with aotual experience in a tone at once passionate and personal" 44 -is a step away from many of Yeats's early enthusiasms. In retrospect, Yeats observed:

Wy own verse has more and more adopted... the syntax and vocabulary of common personal speech.... The over childish or over petty element in some good Wordsworth and in much poetry up to our date comes from the lack of natural momentum in the syntax. This momentum underlies almost every Elizabethan and Jacobean lyric and is more important than simplicity of vocabulary....45

It was suggested above that the development of Yeats's love poetry peralleled the movement from the Petrarchan idealism of the Elizabethans to the "negative emotions" (what Bradbrook oalls "a sharp and bitter poetry") to be found in Jacoboan poetry and drama. Yeats's use of irony with respect to the beloved is introduced in the context of a not quite explioit feeling of bitterness in the volume In the Seven Hoods. The eternality of the poet's love is disrupted by time and age, which belong to the world and wich oppose the poet's dream. The poet's dream of beauty and his quest for a ohangeless love are not altogether dismissed, though the poet-lover 
begins to weary beneath his burden, two aspects of which are straining toward opposite poles. In The Green Helmet, however, the beloved has finally abandoned the poet-lover for reasons similar to those presented previously in "Adam's Curse"; in "Words," this crisis is similarly presented in his thought:

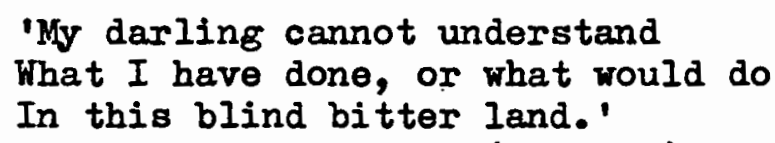

Multiple associations with such words as "done" and "do" (his action, his strength and command of words, and her understanding) illustrate the way in which Yeats achieved a new economy of language while expanding the meaning to a richness we are not quite able to capture in thousands of words. In short, Yeats's poetry is beginning to reflect the ordinary passionate expression of deeply felt personal experience. And this is most convincingly done in plain English. ("...the best I have done/ Was done to make it plain...", 11. 7-8) Had the beloved (in actuality, Maude Gonne) understood what the poet (Yeats) "had done," as the poet suggests, "I might have thrown poor words aray/ And been content to live" (11. 15-16). "Words alone are certain good," the happy shepherd of Yeats's earliest poetry recognizes. But, if words here (in "Words," "No Second Troy" and "Reconciliation") have a comforting effect after love's loss, there certain$2 y$ is no retreat by the poet to that dream of fairyland or that inarticulate misery of the sad shepherd. The poet now embraces what is left him: "...life and letters.../ But an heroic dream" (from "A Woman Homer Sung," 11. 20-1). Language is ever tight, controlled, 
plain, but full of that "passionate syntax" of the active, even agEressive man's speech. William H. Pritchard, in "The Uses of Yeats's Poetry," catches the sense of economy which is coupled with some passionate emotion; referring to "No Second Troy," the next poem in the group, he writes:

The beauty of this poem, and of the best Middle Yeats, is indeed like a tightened bow, on the surface for all to inspect; it doesn't yield any more than does one of Ben Jonson's epigrams (Yeats was reading him at the time) to critical probings af ter complex feelings and significances ... the ' $I$ ' is finally superior to [the beloved], as he is in more obvious ways to the citizens of 'an age like this' who cannot appreciate her. 46

To give a little better idea of what Pritchard has in mind, it might be noted that Jonson's epigrams were meant to be a sort of shorthand picture, an emblem or "example" of the subject he chose to represent. They have one subject and illustrate one attitude toward that subject directly. They were considered texts from which valuable instruction was to be taken-often, as bitter medicine, "full of gall, / Wormewood, and sulphure, sharpe, and tooth'd withall"47_ but they also represented truth and honesty and could be used with complimentary effect, as in the following example:

I Doe but name thee Pembroke, and I find

It is an Epigramme, on all man-kind; Against the bad, but of, and to the good: Both which are ask'd, to have thee understood....48

As a further note, wo might also look to Jonson for an analogy to Pritchard's last statement; seeking examples of what Bradbrook calls "sharp and bitter" Jacobean poetry, we might find there quite a procedent for that "He"-"She" debate we find in Yeats beginning 
with this middle period. In Jonson, the "Charis" pieces and surrounding poems are not epigrams, but they do seem to represent a similar pose to the one Pritchard presents of Yeats in the Maude Gonne poems of The Green Helmet. Charis, for instence, envisioned in "Her Triumph," is a high riding, captivating beauty who is also paradoxically capable of dashing the lover utterly to pieces inspite of his heart. The lover, Ben, presents himself as physically base, but reminds her that

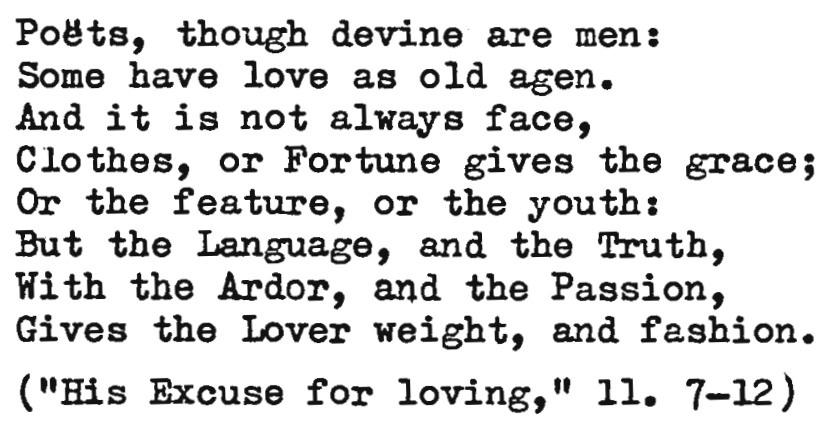

Ben obviously respects and reveres the lady, Charisw-though he sometimes makes fun of her, as he does of himself-but the table seems to be turned in the last two pieces of the set. She rebukes him and presents him with a formal sumnary of what she would have him be, which he must respect, though he must be forlorn to hear it: "Noble; or of greater Blood,.... Young... and faire,... as honest as his Birth... Nor o're praise, nor yet condemne;/ Nor out-valew, nor contemne;/ Nor doe wrongs, nor wrongs receave;..." ("Her man described by her owme Dictamen"). But the final short piece, entitled "Another Ladyes exception present at the hearing," underscores, in an earthy way, a conspicuous oversight in Charis' depiction of the ideal man. As Ben's last word, "Another Lady" outlines in plain language the 
substance of Charis' pronouncement, which proves to be rather worldly, frivolous and, ironically, base: "For his Mind, I doe not care,/ That's a Toy, that I could spare" ("Another Ladyes exception...", 11. 1-2). Charis' own exception of this only quality Ben has to offer-except also his love-is a fundamental flaw which marks her distinctly female; the exception is what makes poets, though men, divine. "A Celebration of CHARIS..." is followed by a group of poems which highlight this sexual difference. The next Under-wood poem, "The Musicall Strife; In a Pastorall Dialogue," presents a Platonic debate of "Hee" and "Shee" reminding one, outside of "Adam's Curse," of Yeats's later poems, "Michael Robantes and the Dancer," "Soloman and the Witch" and "An Image from a Past Life." But the similarity may only be coincidental.

Groen Helmet poems which have been related by scholars to Jonson's work have been cited both as general observation and, of ten more valuably, by specific reference. For example, Edward B. Partridge, in The Broken Compass, ${ }^{49}$ stimulates our "detective interest" by providing the clues which connect an image from the Alchemist (II, $i, 92$ ) and Volpone ( $I, i i, 27$ ), particular enthusiasms of Yeats's at that time (see "The Controversy over The Playboy of the Western World" in The Arrow for February 23, 1907) $)^{50}$ to a similar image in Yeats's bitter epigram, "The Attack on the "Play Boy'" (title later changed and included in Respongibilities). Though the picture which focuses on that "sinewy thigh" is derived from Yeats's comparison of "Griffith and his like to the Eunuchs in Ricketts's [sic.] picture watching Don Juan riding through Hell,"51 Yeats may 
have based the thigh image, a signification of the champion in this 1909 poem, on the "golden thigh" of Pythagoras from Jonson's plays. Supporting this inference is the recurrence later of the same image, as the "World-famous golden-thighed Pythagoras," in "Among School Children" (VI). And the treatment of Pythagoras in such instances as "The Statues" and "News for the Delphic Oracle" (from Last Poems) sugesests that Yeats was reminded of Nano's recitation of the transmigration of Pythagoras into his many forms (cf., rhyme "pass" with "Pythagoras," Volpone, I, ii, 5-6; Yeats's rhyme with "Erass"). Another parallel to Jonson is cited by B. Rajan, in "Yeats and the Renaissance," where he makes the general observation that

Yeats quotes Ben Jonson more than once and, of all the poems of our time, The Fascination of What's Difficult is the most Jonsonian in the run of its verse. 52

To indicate the sorts of things that may have led Rajan to this conclusion, it will be necessary to quote the poem.

The fascination of what's difficult

Has dried the sap out of my veins, and rent Spontaneous joy and natural content Out of my heart. There's something ails our colt That must, as if it had not holy blood Nor on Olympus leaped from oloud to cloud, Shiver under the lash, strain, sweat and jolt As though it dragged road-metal. My curse on plays That have to be set up in fifty ways, On the day's war, management of men. I swear before the dawn comes round again I'll find the stable and pull out the bolt.

The impact of the language is impressive as a feature of that manly, unsentimental, straight-forward mask the poet now wears. Each line has a chiseled sharpness, an edge partly enforced by the frequent 
tendency to halt on final, heavily-stressed, mono-syllable, hard consonant words like "colt," "blood," "cloud," "jolt," "dolt," and "bolt." There is a sense of deliberateness and clear-beadedness about the poem that contradicts the Elizabethan melancholy depicted in its first four lines. Doubtless, the melancholy is related to the first four lines of the poem preceding it, "Against Unworthy Praise:"

0 HEART, be at peace, because Hor knave nor dolt can break What's not for their applause, Being for a woman's sake....

Yeats's adoption of the active man's "passionate syntax," the "natural momentum in the syntax...[which] underlies almost every Elizabethan and Jacobean Iyric," in "The Fascination of What's Difficult" is manifest in actual seventeenth-century vocabulary and, as Henn has called it, "homely even brutal idiom." Those knaves and dolts, mentioned in Yeats's curse of lines 8 through 1l, favorably compare with the "curious fooles, and enuious of thy straine," the causes of Jonson's affliction, "The iust indignation the Author tooke at the vulgar censure of his Play," The New Inn.

...though thy nerues be shrunke, and blood be cold, Ere yeares haue made thee old; Strike that disdaine-full heate Throughout, to their defeate.... ("Ode. To himselfe," 11. 45-8) 53

(In his Autobiography, one finds evidence of Yeats's acquaintance with The New Inn. $)^{54}$ Another interesting feature, however, develops from Yeats's apparently adapted idiom in the phrase, "There's some- 
thing ails our colt," from the fourth line. This has an especially Jonsonian ring, not just in terms of the wit produced as an effect of the various turns in the meaning of "colt" (an inexperienced, awkward, lively spirited, even lascivious or cunning fellow-a young ass); but, as a Pegasus image, it belongs to the tradition that Jonson represents in Discoveries when he writes:

... the Poet must bee able by nature, and instinct, to powre out the Treasure of his minde... Then it riseth higher, as by a divine Instinct, when it contemnes common, and knowne conceptions. It utters somewhat above a mortall mouth. Then it gets a loft, and flies away with his Ryder, whether, before, it was doubtfull to ascend. This the Poets understood by their Helicon, Pegasus, or Parnassus....55

It represents the poet's mind in "Poeticall Rapture," the inspiration of the poet as it freeshim from the earth and soars out with him among the divine. Like Jonson, who bid himself "Come leaue the lothed stage,/ And the more lothsome age" ("Ode. To himselfe," 11. 1-2), Yeats's poet has half a mind to "find the stable and pull out the bolt," leaving behind this loathsome business of "plays/ That have to be set up in fifty ways,/... the day's war with every knave and dolt,/ Theatre business, management of men."

Yeats's attitude and his style had changed immensely by this time. In turning from his Pro-Raphaelite dream of fairyland paradise to the actuality of "my fool-driven land" ("All Things Can Tempt Me," formerly called "Distraction"), Yeats's dealings with reality are represented by a poetry which reflects his passionate struggle with the world. The forms and "seeming needs" of "this vegetable universe" distract the poet in his priestly quest for concord, 
"Unity of Being." As he writes at the end of The Green Helmet, "All things can tempt me from this craft of verse." But that is more and more a part of the "vague and incoherent," early Yeats; "Now nothing but comes readier to the hand/ Than this accustomed toil." In one of the few really specific references that scholars have given attaching Yeats's verse to a corresponding passage of Jonson, J. G. Nichols, in The Poetry of Ben Jonson, notices a thought in "All Things Can Tempt Me" "which may be a reminiscence of Jonson" in The Haddington Kasque. In the last six lines of Yeats's poem, the speaker (Yeats as a poet) addresses himself to the change we as readers have been witnessing in his poetry.

... When I was young,

I had not given a penny for a song

Did not the poet sing it with such airs

That one believed he had a sword upstairs;

Yet would be now, could I but have my wish,

Colder and dumber and deafer than a fish.

The lines which Nichols cites from Jonson's masque are these:

Last, in the FISHES place, sits he, doth say; In married ioyes, all should be dumbe, as they.

(The Hadington Masque, 11. 306-7) 56

This thought may seem particularly cold and pessimistic, but it certainly is not the last word in The Green Helmet. The "penny," which the young poet would not have "given...for a song/ Did not the poet sing with such airs...." is nevertheless tossed in the final poem, "Brown Penny," a gesture of that aristocratic sprezzatura, "To find out if I might love" (1. 4). It seems a most casual gesture 
after the intensity of the body of verse behind it.

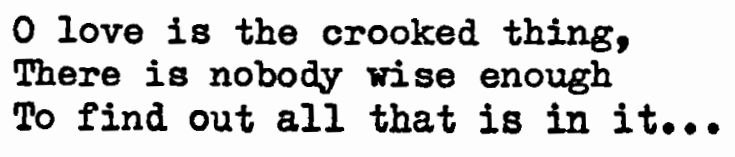

$$
\text { (II. 9-1I) }
$$

And the final effect of this poem is an affirmative launch into the later verse-unlike, in character, that Jonsonian mule kick which ends Responsibilities. Echoing perhaps those "married ioyes" suggested in Jonson's masque, "Go and love, go and love, young man'" is the coin's message (1. 5). "One cannot begin it too soon" is "I's" response (1. 16). Through the next body of verse, Responsibilities (1913-14), Yeats would pretty well complete the turn toward actuality he had begun when he took up the study of the Renaissance in the first few years of this century. Significantly, William Pritchard observes,

...the celebrated turn toward reality in Yeats's poetry from roughly 1903 to 1915 is rather the substitution of one dream for another. The aream of Innisfree is replaced by the poet's creation of tightened structures of rhetoric which protect and exalt him (or... appropriate a worthy other like Lady Gregory to Yeatsian lonely rectitude) even as they frequently say that he has been vanquished, is harassed and worn out... [If] in these middle poems Yeats of ten achieves the 'passionate syntax' he once spoke of, it is to the exclusion of the subjective exploration he later undertook. 57

Pritchard's previously cited impression of the surface beauty of these poems (like a Jonson epigram), is thus reaffirmed. But an important addition must be noted, the inclusion in the picture of $a$ "worthy other"; the increased value of friendship and worthy or aristocratic companions; those "hearts" which are "wild and wise,/ 
And yet not cold" in "The Mask"; and, in "At Galway Races,"

Aye, horsemen for companions, Before the merchent and the clerk

Breathed on the world with timid breath.

(11. 7-9)

A poem such as "A Friend's Illness" illustrates the really high, one might even say, Jonsonian value Yeats places on friendship. (The fellowship of one's own particular "Tribe of Ben" is later celebrated in memory of the "Poets with whom I learned my trade,/ Companions of the Cheshire Cheese," the first lines of "The Grey Rock.") And, in the poem "Upon a House Shaken by the Land Agitation," Yeats begins to reheerse the theme of Jonson's Great House poem, "To Penshurst," when he asks:

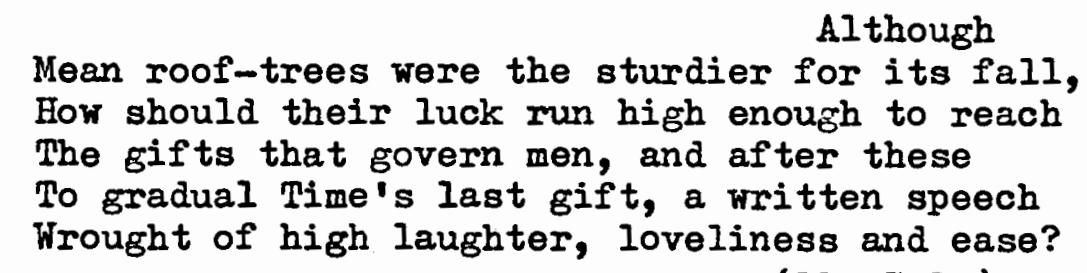

(11. $7-12$ )

In later verse, Yeats repeatedly used this theme in creating Great House poems of his own, magnificent works like "Coole Park, 1929 " and "Coole Park and Ballylee, 1931," works which number among his finest achievements. Such great performances were not achieved, however, without earlier trials. All of the right impulses were there by the year 1912. But what was needed was some significant stimulus to launch them into poetry. That stimulus came in a new controversy nearly as exasperating for the poet as the reception of The Playboy had been for the playwright. 
V. RESPONSIBIIITIES

In the last chapter, something was said about the famous YeatsMoore feud. Yeats had been trying to raise support for the Lane Gallery, a proposed building to house the priceless collection of paintings which belonged to Eugh Lane, Lady Gregory's nephew. According to Yeats, the appeals he had made to the Irish aristocracy made no mention of the middle classes. But George Moore attacked him as though they had. Lady Gregory had also been assaulted in a portion of Moore's memoirs, Hail and Farewell, which was being published in The English Review (January, 1914). But when he got around to Yeats, whom he considered a "literary fop," Moore depicted the scene of a speech Yeats had delivered in 1904, after returning from a lecture circuit in America. With noticeable malice, Moore writes:

As soon as the applause died away Yeats who had lately returned to us from the States with a paunch, a huge stick and an immense fur overcoat, rose to speak. We were surprised at the change in his appearance, and could hardly believe our ears when, instead of talking to us as he used to do about the old stories come down from generation to generation, he began to thunder like Ben Tillett himself ageinst the Hiddle Classes, stamping his feet, working himself into a great passion, and all because the middle classes did not dip their hands into their pockets and give Lane the money he wanted for his exhibition. It is impossible to imagine the hatred which came into his voice when he spoke the words 'the middle classes'..... And we asked ourselves why Villie Yeats should feel himself called upon to denounce the class to which he himself belonged essentially: one side excellent mercantile millers and shipowners, and on the other a portrait painter of rare talent. With so admirable a parentage it did not seem to us necessary that a man should look back for ancestry, and we had laughed at the story...58

For her part in the quarrel, Lady Gregory, backed by Yeats, threatened a libel suit and persuaded Moore to take back some of his remarks 
about her; but Yeats, who had been on bad terms with Moore since their collaboration on the 1900 play, Diarmuid and Grania, met Moore's challenge with a just revenge of letters. In 1909, for instance, he had written in his diary:

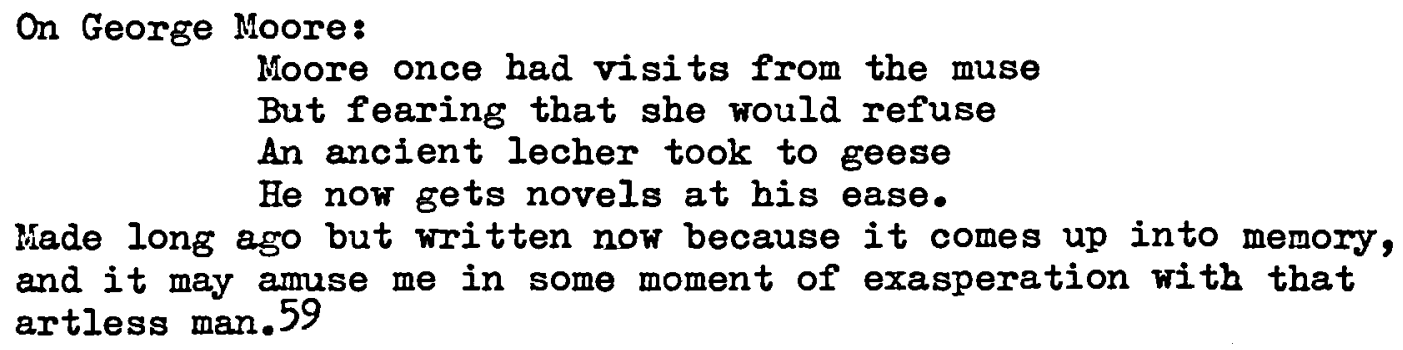

Similarly, he comforted Lady Gregory against lloore in the Responsibilities poem, "To a Friend Whose Work has Come to Nothing:"

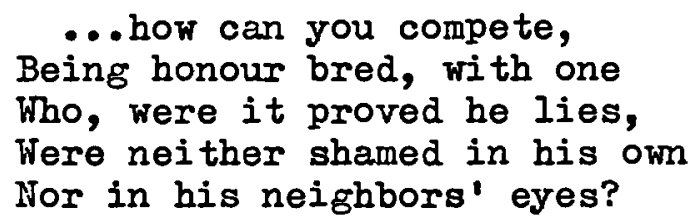

And, as shown in the last chapter, Yeats denied having made any mention of the middle classes in the particular speech Moore had described, saying that Moore had confused that speech with another given at the National Literary Society, "which [Moore] did not hear but would have heard of."60 In this second speech, however, he had used the word "bourgeois" in the same sense that one finds in Jonson's use of the word "cit," which Yeats pretended to suppose to be a mere "word of artistic usage." Perhaps encouraged by Pound, who was spending the winter of 1913/14 with him at Stone Cottage, Sussex, and to whom he dictated much of his work, Yeats sharpened 
the temper of his counterattack on Moore and the middle class. In the same passage of Yeats's Memoirs which answered Moore by citing Jonson (ostensibly dated "January 1914," the month of Moore's attack in The English Review), Moore is represented as "the born demagogue ...He has always a passion for some crowd, is deliberately inciting them against somebody."6I Pound, who temporarily raised the ire of Yeats by making some unauthorized changes in some five of Yeats's poems of this period, 62 was a flamboyant, if incalculable influence on Yeats at that time and for the next few years. If it is doubtful, as Yeats seems to argue, thet he could have maligned the middle classes in the ridiculous fashion portrayed of him in his 1904 speech for the Lane pictures, it is not improbable that Hoore had something of a case against him and the rhetoric he was using by 1913, when Pound was almost in constant contact with him. Still pleading for his municipal gallery of modern art, for example, in a speech given at the Court Theatre, Iondon, July 14, 1913, Yeats finished with these words:

If the intellectual movement is defeated, Ireland will for many years become a little huckstering nation, groping for halfpence in a greasy till. It is that, or the fulfillment of her better dreams. The choice is yours and ours. 63

As it has been noted, 64 "groping for halfpence in a greasy till" is strikingly repeated, only slightly modified, in Yeats's bitter poem, "September 1913," which was first printed less than two months after this speech was delivered.

As a direct result of this controversy, Yeats erected his first verse monument to one of several ancient houses celebrated in his 
poetry. And it is at this point that we see the two espects of Yeats's strongly aristocratio temperament, his scorn for the many and his praise for the worthy fow, distinguished for the first time by the forms used by Ben Jonson for similar purposes. There are long poems, short poems, sonnets and epigrams; but what perhaps is most striking is that Responsibilities is filled with an extraordinary amount of occasional verse. Yeats's impulse to commend the worthy fer, like Jonson, in ereat moving verse-epistles and his impulse to condemn the mob, Iike Jonson, in biting odes and epigrams is a development-not quite fully realized in Responsibilitieswhich we see in symbolic polarity when we view the famous Prologue and Epilogue which cap the ends of the book. According to Joseph Hone, in W. B. Yeats, 1865-1939, both of these poems were written as a direct result of the Moore-Yeats controversy (Jenuary and Februery, 1914) in an effort to "turn the table on George Moore of Moore Hall. $" 65$

The Prologue, frequently referred to as "Pardon, old fathers," is Yeats's tribute to his ow ancestral house-though as yet he has no actual house or progeny of his owm-Butlers, Armstrongs, Yeatses and Pollexfens, those who represent the "Merchant and scholar who have left me blood/ Thet has not pessed through any huckster's loins" (11. 7-8). Yeats doubtlessly felt such personal tribute necessery in answer to partioular charges Moore had made against his pretensions of being an aristocrat. For Moore had added, in his attack on Yeats in Vale: 
AE who is usually quick witted should have guessed that Yeats's belief in his Iineal descent from the great Duke of Ormonde was part of his poetic equipment.... It did not oocur to us till this last minute, but $A E$ knew that there were spoons in the Yeats family, bearing the Butler crest just as there were portraits in wy family of Sir Thomas More, and he should have remembered that certain passages in The Countess Cathleen aro clearly derivative of the spoons. 66

At Stone Cottage with Pound, January, 1914, Yeats addressed himself to Moore's remarks. After declaring Jonson the model for his use of the word "bourgeois," Yeats wrote in his journal,

I have been told that the crudi ty common to 211 the Moores came from the mother's family, Mayo squireens, probably half-peasants in education and occupation, for his father was a man of education and power and old descent. His mother's blood reems to have affected him and his brother... There has been a union of incompatibles and consequent sterility. 67

In "Pardon, old fathers," a poem T. S. Ellot callod "that violent and terrible epistle dedicatory to Responsibilities, where is first fully evinced Yeats' [sic.] power of speaking as a particular man to men,"68 Yeats opposes himself to that "consequent sterility" of Moore. And the last four lines demonstrate not only the cruoial evidence of his own virility, but a certain recourse to poetio tradition.

Pardon that for a barren passion's sake, Although I have come close on forty-nine, I have no child, I have nothing but a book, Nothing but that to prove your blood and mine.

Rupin Desai, in Yeats's Shakespeare, recognizes in these Iines a commonplace Elizabethen idea of a "poet's verses substituting for a flesh-and-blood heir." The idea is at the root of Jonson's touching line from "On Mirst Sonne" (Epigrammes, XIV), "... gay here doth Ije/ Ben. Jonson his best piece of poetrie." But Desai is convincing 
in his claim that this passage in Yeats was inspired by "Jonson's famous lines in his panegyric on Shakespeare prefixed to the First Folio..." (also In Jonson's Ungathered Verse, XXVI, Herford and Simpson, eds.):

.... Looke how the fathers face

Iives in his issue, euen so, the race

Of Shakespeares minde, and manners brightly shines

In his well torned, and true-filed lines.

(11. 65-8)

This thought represents Jonson's regard for Shakespeare's volume of plays as the fit offspring of Shakespeare's genius, "perhaps a consolatory gesture to the shade of Shakespeare for the death of his only son, Hamnet, in 1596," Desai conjectures. That Yeats knew this poem well, Desal says there is "no doubt." And there is substantial evidence in the Essays and elsewhere, in Yeats's remarks about Shakespeare, to uphold this belief; Yeats was simply thoroughly familiar with Jonson's discourse on Shekespeare, a rare contemporary picture of the Bard written by an admirer and close friend.

The virility, the blood, one might say the "sanguineous temperament" of the artist (in contrast to Moore, "that artless man") is then responsible for "the book," the issue of his genius and, with the Epilogue, the book ends with a sufficiently powerful demonstration of poetio gusto and poetic scorn to invite a comparison with it and "The Fescination of What's Difficult," a poem discussed earlier for its Jonsonian characteristics. Not surprisingly, given the overt quotation of Jonson in the Epilogue, a number of critics have had something to say regarding it. As a sonnet, it is not too long to quote in full. 
While I, from that reed-throated whisperer Who comes at need, although not now 28 once A olear articulation in the air, But inwardly, surmise companions Beyond the fing of the dull ass's hoof -Ben Jonson's phrase-and find when June is come

At Kyle-na-no under that ancient roof

A sterner conscience and a friendlier home,

I can forgive even that wrong of wrongs, Those undreamt accidents that have made me - Seoing that Fame has perished this long while, Being but a part of ancient ceremonyNotorious, till all priceless things Are but a post the passing dogs defile.

The poem is a single sentence; and, given its two more or less casual interjections (11. 6 and 11-12), it conveys a sense of actual speech while surging forward with the compressed power of one magnificent and startling thought. The "reed-throated whisperer," according to George Saul in his Prolegomene, 70 "One presumes... to be the Muse." One could possibly argue, instead, that it also has the more peculiar ring of those ghostly epirits of imagination, who, like Virgil in Jonson's Poetaster, Yeats supposed were "So rammed with life they can but grow in life with being." 71 But it hardly matters which. Perhaps, for our purposes, the Muse will be the most useful identification. It is not olear which of two sources Yeats used for his borrowing from Jonson. But it is clear that he once tried to maintain the archaic spelling of Jonson's phrase. Peter Allt and Russell Alspach, In The Variorum Edition of the Poems of H. B. Yeats, indicate that, for years, printings of the poem bore the spelling in line 5 of "ess's hoof" as "asse's hoof."72 In "An Ode. To Hillselfe," a poem from Under-wood, Jonson's last stanza readss 
And since our Daintie age, Cannot indure reproofe, Make not thy selfe a Page; To that strumpet the Stage, But sing high and aloofe, Safe from the rolves black jaw, and the dull Asses hoofe. (12. $31-6)^{73}$

Elsewhere in Jonson, the last two lines are virtually repeated; but the rest, of course, is quite different. In "an apologeticall DiaIogue" entitled "To the Reader," which appears at the end of The Poetaster, a play that we know Yeats was familiar with, Jonson asgigns these last words to the speech of the "AVTHOR:"

I, that spend halfe my nights, and all my dayes, Here in a cell, to get a darke, pale face, To come forth worth the iuy, or the bayes, And in this age oan hope no other graceLeave me. There's something come into my thought, That must, and shall be sung, high, and aloofe, Safe from the wolves black iaw, and the dull asses hoofe. (11. $233-9)^{74}$

Yeats's poem is at once a resolve to "sing high and aloofe," in accordance with the thought Jonson's phrase represents, while it also admits, as Thomas Whitaker notioes in Swan and Shadow, that its poet "but imperfectly incamates... the light of an inward voice or luminous wind," the Muse. 75 Like our ailing colt from "The Fascination of What's Difficult" (the Pegasus image which represents inspiration rising to "Poeticall Repture"), the "reed-throated whisperer/ Who comes at need" is no longer "A clear articulation in the air." The melancholy stete of the artist, which was consistent with the hot and bitter humors of Jonson in Yeats's Green Helmet poem, is just as bitter here, though perhaps not as heated. Like Jonson, who bids 
himself "leaue the lothed stage," the poet in "Fascination..." is ready to "find the stable and pull out the bolt." But the speaker In the Epilogue to Responsibilities, 28 we find in the deferred main clause of the poem's single sentence, announces "I can forgive even that wrong of wrongs," which he then goes on to characterize by "adapting a metaphor from Erasmus," "a post the passing dogs defile."76 The forgiveness is not marked by a shift from scorn to compassion for his enemies. The persone has come to "A sterner conscience and a friendlier home" ("Kyle-na-no under the ancient roof"; part of the Coole Park demesne of Lady Gregory). The ailing colt of his poetic powers, however, is still strong here, as we see by interpreting the phrase, "although not now as once," to mean more nearly a diminished idealism, rather than a tapering off of skill which would contradict what we clearly observe to be the growing strength of Yeats's verse. Yeats's visits from the Muse set him distinctly opposite Moore, whom he had satirized in his diary as "An ancient lecher" whom the Muse refused to approsch. What the poet forgives is not so much "the passing dogs" or "the dull asses," but his having to oppose them in this "Notorious" manner. This business may seem distasteful to the reader; as J. G. Nichols writes, generally

we shall not like [Jonson's] "An Ode. To Himselfe" if we dislike the expression of pride and scom. In this, I find Jonson very aimilar to Yeats who also has won the admiration of many who dislike his attitudes.

(The Poetry of Ben Jonson) ${ }^{77}$

But such a position is of certain value and possibly of necessity to the poet. In this line, Harold Bloom, in Yeats, rrites: 
Moore is another sign that the present has fallen away from ancient ceremony, and so it is no wonder that notoriety (of the kind Moore enjoys and brings) repleces aristocratic "Fame," which has perished. Ieats "can forgive" because he has assumed the responsibilities of becoming the continuator of a living tredition, however dimmed it be in a world of Hoores. 78

T. HoAlindon places a somewhat different emphasis on the poem when he stresses the appearance of the Jonson phrase and suggests that Yeats was acting like Jonson, who, in "To the Reader," leaves the wolves and dull asses, which signify the multitude, "to their fate and withdraws majestically into a solitude where be will sing much higher strains and be quite content with a small but discriminating audience..."79 Perhaps McAlindon was also thinking of Yeats's withdrawal from the stage to the more private company of his "Plays for Danoers" which was simultaneously taking place. Aside from this difference with Bloom's interpretation, however, an interpretation which follows Yeats's text more closely then does McAlindon's, we may read the poem as though both the interjeotion of "Ben Jonson's phrase" (1. 6) and the interjection of lines 11 and 12 , concerning the "Fame" which was "a part of ancient ceremony," are related. An Important point, for instance, that Donald Davie makes on two separate occasions, in "Michael Robartes and the Dancer"" and "Yeata, The Master of a Trade," is that neither the explicit naming of Jonson nor the quotation from Jonson is as important as the particularIy Jonsonian idea represented in the line "Being but a part of ancient ceremony." 80 The particular direction Davie suggests we look is ahead, toward the later poems, "A Prayer for my Daughter" and "The Second Coming," where "ancient ceremony" is of central sig- 
nificance. It might be suggested here, however, that "Fame" which "has perished this long while,/ Being but a part of ancient ceremony" is also the subjeot both Horace and Caesar address themselves to in The Poetaster, in those lines Yeats accommodated to his ow romantic vision of the imagination in its condition of fire and its "purifying simplification through intensity," all referred to in the first ohapter.

[Horace.] And for his poesie, 'tis so ramm'd with life, It shall gather strength of life, with being, And live hereafter, more admir'd, then now.

$$
(v, i, 136-8)
$$

[Caesar.] To shew, your titles are not writ on posts, Or bollow statues, which the best men are, Without Promethean stuffings reacht from heaven:

$$
(v, i, 14-16)
$$

Furthermore, having made this last association, it seems possible that the last two lines of Yeats's Epilogue, which are an adaptetion of a metaphor from Erammus that he noted in his 1930 Diary, may have been suggested by Joneon's caution "To shew, your titles are not writ on posts,/ Or bollow statues." As Yeats was thinking of these passages when he spoke of "Promethean fire," "hollow statues" and "hollow Images" in the essays of Discoveries, The Autobiography, Nemoirs and elsewhere, the final metaphor of the Epilogue may have evolved, in the process of composition, from an image of impotence (resembling his blast at Moore in Memoirs, which is adfoined by a reference to Jonson) before it became the profane image adapted from Erasmus, "till all my priceless things/ Are but a post the passing 
dogs defile." However that may be, as a parting word to the poem, we may once again quote Bloom:

Responsibilities ende by coming full circle, in defence of self and companions against George Moore, taken as representative of the decadence of an objective age. Yeats mounts to invective, justified presumably by the larger, supposedly cultural iseue.... Overtly quoting Ben Jonson, and adapting Erasmus to his own purposes, Yeats clearly tried for a rather serious effect here, and he would have been delighted to encounter in his exegetes such deference due to a poet of his degree... The wind among the reeds blows again here, but now inwardly, the poet claims, and it gives the poet what he needs, not inspiration, but a sense of community with the mighty dead, invoked throughout Responsibilities. Armed with that sense, the poet will hie him to Lady Gregory's, and under her roof will find that he can forgive even George Moore, who is merely an accident of historical decline..." 81

It has already been remarked above that in "The Grey Rook," the long first poem of Responsibilities, there is a celebration of Yeats's "tavern comrades," "Poets with whom I learned my trade,/ Companions of the Cheshire Cheose," which seems reminiscent of such celebrations of worthy fellowship as are known to have been produced by Jonson and his "Tribe of Ben." We may recall Herrick's "An Ode for Ben Jonson," or Jonson's "An Epistle Answering to One Thet Asked to Be Sealed of the Pribe of Ben." There is no hard evidenoe that Yeats had Jonson in mind when he wrote "The Grey Rock," yet it seems certain that he had. A statement in the Autobiography seoms to distinguish Jonson by his usual role of leadership-so that he was the antecedent of a type which was common in Yeats's group as he remembers them. To repent McAlindon's words, for Yeats, Jonson represented "a type of pre-modern poet whose vigorous comic art proceeded from a contemptuous indifference to mere logic and general approval." 
As Bloom has just been quoted as saying, "Responsibilities ends by coming full circle, in defence of self and companions against George. Moore, taken as representative of the decadence of an objective age." What then, we may ask, do Yeats's companions and Ben Jonson have in common? And how does Yeats use Jonson to represent them? CollectireIy, we observe, it is their anti-Science. He is their pre-modern example, a champion of literature and Art-for-Art, an advocate, a terror against decadence.

Yet, even apart from Beardsley, we were a sufficiently distinguished body: Max Beerbohm, Bernard Shaw, Ernest Dowson, Iionel Johnson, Arthur Symons, Charleo Conder, Charles Shannon, Havelock Ellis, Selwyn Image, Joseph Conrad; but nothing counted but the one hated name. [Science.] I think that had we been challenged we might have argued something after this fashion: "Soience through much ridicule and some persecution has won its right to explore whatever passes before its corporeal eye, and merely because it pesses: to set as it were upon an equality the beetle and the whale though Ben Jonson could find no justification for the entomologist in The New Inn $[i$ or, The Light Heart], but that he had been crossed in love. Iiterature now demands the same right of exploration of all that passes before the mind's eye, and merely because it pesses." Not a complete defence, for it substitutes a spiritual for a physical objectivity, but oufficient it may be for the moment, and to settle our place in the historical process. 82

In the great remainder of the Responsibilities poems that we have not discussed, one is likely to find occasional references to Yeats's debate with Moore and other actual frustrations in his life. Concerming the Lane Gallery project, for instance, we have "To a Wealthy Man Who Promised a Second Subscription to the Dublin Municipal Gallery If it Were Proved the People Wanted Pictures," which praises the aristocracy with the likeness of Guidobaldo's court in order that they might "Iet Paudeens play at pitch and toss,/ Iook 
up in the sun's eye and give" (11. 31-2). "To a Friend Whose Work Has Come to Nothing," a poem which we have already associated with Lady Gregory and Moore, is one of the few examples, aside from the Prologue and Epilogue, in which critioism has also mentioned the name of Jonson; for Harold Bloom has said,

The epigrammatic strength and stoic knowingness of Landor, and perhaps also of Jonson, are felt again in To a Friend Whose Hork Has Come to Nothing, probably Yeats's most enduring tribute to bis Indispensible patroness, Lady Gregory. 83

In poems like these-"The Grey Rock," "Friends" (also in the 1912 Green Helmet), "Paudeen," "September 1913"-Yeats has turned to an occasional verse; he is a public man in actuality and his poetry has adopted a public voice to express both what he admires and what he faults. But in this volume, unlike The Green Helmet which is valued primarily for its surfece beauty and its full powerful exercise of that active voice and "passionate syntex," the poetry has now begun to admit the contemplative character of the poet's genius in what Pritchard calls "the subjective exploration be later undertook" (see above). His poetry seems most contemplative when addressed to his friends, worthy companions and his aristocratic values, "all my priceless things." Otherwise it is coldly direct, brilliently explicit in the delivery of a prized insult. And this does not mean that his meditative verse reverts to his early use of shadows and obscure symbols. Yeats uses, for the most part, images and speech which give the impression of a passionate man's thought; and this practice is attributable to his renered interest in poets like Jonson, Byron, Donne and Burns, poets who deal, as Meir says, "In a tone at once passion- 
ate and personal" (also above). "Tragic joy," whioh is associated with the aristocratic ideal of sprezzatura and represented in "The Grey Rock" as "the gods with laughing Iip" who are betrayed by the "false faces" of men who drink surreptitiously from Goban's cup, "tragic joy" becomes an implicit undercurrent in Yeats'g meditation. And Yeats's tragic vision of "The Second Coming" is anticipated by a poem which has been more or less casually associated with Jonson. T. R. Henn, in The Lonely Tower, writes:

Besides 'The Cold Heaven', the important poem in Responsibilities is 'The Magi'.... The Magi are.... part of Yeats's 'capricious and variable world'. As in Ben Jonson, they tell of a prodigious and monstrous birth, a threat to the land. 84

It is difficult to pinpoint what particular example of Jonson's work, if any, Henn had in mind in making such a comparison. One is satisfied, however, that it must have been a general, rather than a partioular observation. Perheps the Magi, seen, as Bloom observes, "unnatural, in 'their stiff, painted clothes,' as though part of a roadaide creche,"85 euggest the masked participants of Jacobean court entertainment; Henn's "prodigious and monstrous birth" might then suggest the anti-masque. Similarly, the anti-masque of Renaissance Iondon, represented in a city comedy like The Devil is an Ass, with its business and debauchery, inflation of titles, deflation of morality, a picture of the world grown so rotten that it is unfit even for the devil, perhaps something of this sort came to mind. In poetry, Jonson makes similar judgments upon men, dividing them into two classes: the true courtier or aristocrat, and the "false faces." A tragic vision of the "worsening world" and an "inexplicable movement" 
toward degeneracy and objectivity may be suggested by the followings

O Times! O Manners! Surfet bred of eage, The truly Epidemicall disease!

'T is not alone the Merchant, but the Clowne, Is Banke-rupt turn'd! the Cassock, Cloake, and Gowne,

Are lost upon accompt! And none will know

How much to heaven for thee, great Charles they owe!

("An Epigram. To Our Great and Good K. Charles on His Anniversary Day," 11. 17-22)86

Goe on, increst in vertue; and in fame:

And keepe the Glorie of the English name,

Up among Nations. In the stead of bold

Beauchamps, and Nevills, Cliffords, Audley's old;

Insert thy Hodges, and those newer men,

As Stiles, Dike, Ditahfield, Millar, Crips, and Fen:

That keepe the warre, though now't be growne more tame,

Alive jet, in the noise; and still the same;

-... Soone

Should he heare of billow, wind, and storme,

From the Tempestuous Grandlings, who' 11 informe

Us, in our bearing, that are thus, and thus,

Borne, bred, allied? what's he dare tutor us?....

Let poore Nobilitie be vertuous: Hee

Descended in a rope of Titles, be

From Guy, or Bevis, Arthur, or from whom

The Herald will. Our blood is now become

Past any need of vertue. Let them care,

That in the Cradle of their Gentrie are;

To serve the State by Councels, and by Armes:

We neither love the Troubles, nor the harmes.

What love you then? your whore? what study?....

("A Speach According to Horace," 11. 49-56, 62-6, $79-87)^{87}$

While it is not clear what particulars Henn had in mind, be informs us of a similarity of vision between Yeats and Jonson which will be userul later, while we examine the sister poems, "A Prayer for my Daughter" and "The Second Coming," for their use of "ancestral ceremony," an especially Jonsonian value.

The last poem in Responsibilities, preceding the Epilogue, is

"A Coat." 
I made my song a coat

Covered with embroideries

Out of old mythologies

From heel to throat;

But the fools caught it,

Wore it in the rorld's eyes

As though they'd wrought it

Song, let them take it,

For there's more enterprise

In walking naked.

Harold Bloom has related this poem to Moore's tale of the "immense fur overcoat" that Yeats wore when he gave his diatribe against the middle olass. 88 In addition to what was quoted above, Moore complained that "the old green cloak that was in keeping with [Yeata's] profession of romantic poet" had been replaced by the fur coat "which distracted our attention from what he was saying." 89 Bloom observes that it is probably better that in his poetry Yeats had, metaphorically speaking, doffed that "magnificent fur coat." But the poet's additional departure from his romantic "embroideries" to the rar stuff of Responsibilities is also, by this time, complete and is justified by the poet: "there's more enterprise/ In walking naked." Furthermore, "A Coat," a poem that precedes the Epilogue where Jonson is quoted, may also have been influenced by Yeats's reading of Jonson. As Nichols writes, it "sounds to me as though it were suggested by this:

Iff Men, and tymes vere nowe Of that true fface

As when they both were greate, and both knewe howe that ffortune to imbrace,

By Cherissheinge the Spirite $y^{t}$ gaue their greatnesse

I then could rayse my notes Lsrace:

Lowd to the rondringe thronge

And better Blason them, then all their Coates, 
That were the happie subiect of my songe.

["ode," Ungathered Verse, XIVIII, 11. 1-9]

Nichola continuess

The two passages are similar in their pride and scorn, and in the connection which they both make between 'Coates' and 'songe'. The different meanings of 'cont' in the two passages (garment in Yeats and heraldic coat in Jonson) suggest that the borrowing, if there was one, was largely a recollection of sound. It may be of significance that Yeats's poom was first published within a few months of "While I, from that reed-throated whisperer' which admits to a reminiscence of Jonson, 90

Yeats's persone in "A Coat" is typical of the Responsibilities oollection. The poet or, in this case, the singer, one who walks before "the world's eyes," is mocked by "fools" who wear his garment of song "As though they'd wrought it." As George Wright points out, "it is this opposition between the passionate man and the figure he cuts in the world's eyes which defines Yeats's treatment of his personse", 91 and it is in Yeats's next body of verse, The Wild Swans at Coole (1917 and 1919), that we first witness, according to Wright, Yeats's "mature use of this technique to present both bimself and other personae as ironic heroes. 1192

\section{IATER POEMS: THE OCCASIONAI FOBM}

The poem from Wild Swang at Coole most of ten singled out as the outstanding poem of the collection is "In Memory of Major Robert Gregory." The poem most often singled out as the poorest is "Shepherd and Goatherd," for a while known as "The Sad Shepherd," but not to be confused with Yeats's early poem which bears the name of Jonson's 
play. What these two poems have in common is that they are both elegies to the same man, Robert Gregory, and each represents Yeats's exploration into the elegaic poetry of the English Renaissance to find a form which would best serve as the expression of great loss that he felt the airman's death had been to himself and to his patroness, Lady Gregory. Often, as in the generalized comment Rajan makea, the scene of this entire body of verse is "At Kyle-ne-no under that ancient roof" from the Epilogue of Responsibilities. Rajan casually observes:

Coole Park is also Penshurat, briefly graced by "Our Sidney and our perfect man." Yeats strengthens the associations by mourning Major Gregory's death both in a Renaissance pastoral and in an elegy the stanza of which is taken from Cowley.93

The credit goes to Frank Kermode, in The Romantic Imase, 94 for the discovery of Yeats's debt to Abraham Cowley. Though, as McAlindon thinks, Yeats's use of the stanzaic pattern of Cowley's "Ode on the Death of Mr. Hilliam Harvey" does not completely account for the tone of Yeats's poem, the selection of Cowley's stanza for "In Memory of Major Robert Gregory" does represent an important reference to Renaissance tradition in a body of Yeats's poetry which wes to become his finest achievement, poems which represent his "subjective exploration" and his tribute to aristocratic values such as custom, ceremony, friendship and patronage of an honored few, well-wrought beautiful thinge. To repeat an observation made before, we can see that as Yeats's poetry beoomes more and more occasional, public and, in voice, proud and aristocratic, it becomes more traditional in form 
and often in content. His experiment with Cowley's stanza was successful not only in this funeral elegy to Robert Gregory, but it was repeated effectively in "A Prayer for my Daugher" and in the second poem of "The Tower" sequence, at which point we witness the splendid shift to the ottava rima stanza of "Sailing to Byzantium," "Meditations in Time of Civil War" (parts I, "Ancestral Houses," and IV, "My Descendants"), "Nineteen Hundred and Nineteen" (I), "Among Sohool Children," "Coole Park, 1929," "Coole Park and Ballylee, 1931," "Vacillation" (II, III), "A Koman Young and OId" (VIII, "Her Vision in the Hood"), "Parnell's Funeral," "The Gyres," "The Municipal Gallery Revieited," "The Statues" and "The Circus Animals' Desertion." Cowley's stanza, aside from oertain poetio weaknesses of the author which Yeats avoided, was of use to Yeats in the following ways acoording to Kermodes

Cowley'a characteristically uneven, over-long and over-witty poem lacks the design of Yeats's, and what structure it has is partly prefabricated, deriving from the conventional Renaissance funeral elegy, which is both schematic and witty. But, as far as I know, Cowley invented the stanza, and having seen Yeats use it, we may be prepared to grant that it has great virtue. It has balance and variety, and in the long concluding line Cowley began an experiment in the elegaic possibilities of slow, heavily retarded monosyllabic movement, which Yeats was happy to continue.... Yeats here practices a poet's not a oritio's imitation. William Harvey was not a Sidney, but he was, according to Cowley, a many-sided genius who died young, and the poem which commemorates him struck certain chords that interested Yeats; he therefore imitated it.95

The similarity of the stanza patterns used by both Cowley and Yeats is not to be disputed, but Kermode's suggestion that Cowley's Mr. Harvey provided the sufficient example of the "Renaissance hero" which "brought to a happy issue that preoccupation with Sidney and 
the Renaissance elesy which was forced on the poet" 96 is open to debate. T. MaAlindon, in "Yeats and the English Renaissance," partIy refutes Kermode's claim and makes one of his oxm. Though "compliceted by reminiscences in Yeats's poem of Spenser's anaemic elegies on Sidney" and by Kermode's claim for Cowley, McAlindon suggests that Yeats's poem be compared with Jonson's "To the immortall memorie and friendship of that noble paire Sir Iucius Cary and Sir. H. Morison" (Under-wood, IXX), where

But a comparison of Yeats's poem with Spenser's and Cowley's, or with any other funeral poem of the Finglish Renaissance, vill be found to throw into relief its resemblences to Jonson's ode.97

Yeats's first attempt to memorialize Gregory by writing a pastoral elegy based on Spenser was unsuccessful and left the poet unsatisfied. Therefore it is supposed that he browsed around further until he lit upon Cowley. Meanwhile (still oupposition), he discovered Jonson's ode, or knex it already, and adopted its tone while adopting Cowley for mere technical advantage. In this vein, McAlindon reasons,

The subject of Corley's ode, one must observe, is a gentle Cambridge soholar, not an aristocratic heros its tone is melancholic and even sentimental-not, like that of Jonson and Yeats, grand, triumphant, heroics and, as Yeats would surely have noted in his exploration of the very slight body of valuable elegeio poetry in the sixteenth and seventeenth centuries, this ode-its stanza form apart-is good just insofar as it is directly indebted to that of Jonson, Corloy's accepted master in many things.98

In short, MaAlindon argues that Cowley suggested the form and Jonson the content of Yeats's poem. And the textual similarities 
are three-fold in kind. First, each poem commemorates a joung man whose death occasions the poems Henry Morison and Robert Gregory. In both Instances, Mcalindon writes, the young men are "clearly idealized with the Sidneian model in mind." 99 Jonson, who never addressed a poem directly to Sir Philip Sidney, did honor him through a number of epistles, odes and epigrams addressed to members of his family (Epigrammes, IXXIX, CIX; The Forrest, II, III, XII, XIV); for Jonson, as for Yeats and Spenser, Sidney was the epitome of the aristocratic hero, the total Renaissance man. Accordingly, the poem by Jonson and the poem by Yeats resemble one another insofar as they draw on a common model. The subjects of both poems, like Sidney, died in combat at an "imperfect" age. In Jonson's "To the immortall memorie..."

Alas, but Morison fell young:

Hee never fell, thou fall'st, my tongue.

He stood, a Souldier to the last right end, A perfect Patriot, and a noble friend, But most a vertuous Sonne. All Offices were done By him, so ample, full, and round, In weight, in measure, number, sound, As though his age imperfect might appeare, His Iife was of Fumanitie the Spheare.

$$
\text { (st. 5, 11. 43-52) }
$$

Similarly, in Yeats's "In Memory of Major Robert Gregory," "my dear friend's dear son,/ Our Sidney and our perfect men" (VI, 11. 46-7), is furthermores

Soldier, scholar, horseman, he As 'twere all Iife's epitome. What made us dream that he could comb grey hair?

$(X I, 11,86-8)$ 
But this first object of commemorating the dead son and "noble friend," a consolation to the parent and the surviving friend, succeeds, in both poems, in raising the ocoasion from the plain of consolation, or solace, to that of celebration, the second similarity between the two poems. According to Jonson, life is not "measur'd by the space" or time, but "by the act" (11. 21-2); "life doth her great actions spell,/ By what was done and wrought/ In season, and so brought/ To light..." (11. 59-62). And in Jonson, the poem, a song, also declares itself to be a constellation where "Two names of friendship" shine as "one Starre:/ of hearts the union" (11. 98-9). Jonson's poem oelebrates the friendship of two men, Cary and Morison ("Friendship, in deed, was written, not in words:/ And with the heart, not pen"; 11. 123-4). Yeats's poem, provoked by the thought of lost friende-Lionel Johnson, John Synge, George Pollexfen, now Robert Gregory ("that last death took all my heart for speech," 1. 96)-is a celebration of friendship as it honors the memory of a kind of life these friends exhibited which is passing from the world. It is Gregory's escape into the world of action and deeds, however, that distinguishes him from these other friends-and Yeats himself, as an isolated tower poet-and which affirms his loss in a celebrative light, startling the poet into the thought which rises to the poems and this is the third similarity between the two poems 2 the intrusion into the poem of the actual person of the poet and his meditation on life and death.

In Jonson's poem, what is "immortall" is not Morison's life, as a perfect man, or particularly his life after death, but the "memorie 
and friendship of that noble paire..." Cary and Morison. And this is exactly where Yeats and Jonson meet; for, in Yeats, as we have so often seen, the "passionate dead" have their reward of immortality in the memories and imaginations of those still living ("Soldier, scholar, horseman, he,/ And yet he had the intensity/ To have published all to be a world's delight"; 11. 71-2). What Morison has egcaped by an early death is, as McAlindon puts it, "the lethargio longevity of another man [not Cary, but one whom Jonson refers to as "Stirrer," 1. 307 who began his manhood with promising vigour but was quickly "sunke in that dead sea of life'" (1.40). 100 Robert Gregory's death permits him an exit from life with the promise of his youth, in the glory of a bero. The difference between Gregory and Yeats's three other friends, "All those that manhood tried, or childhood loved" (1. 75), is in the same vein as Jonson's hero. Yeats's meditation falls first upon the tragedy of Iionel Johnson and his inability to achieve "A measureless consummation that he dreamed" (1. 32). Next to appear is the dead synge who, obsessed by a dream of art, suffered from the bad fortune of a protracted 11Iness which both caused the obsession and prevented Its realization ("We should unite stoicism, asceticism and ecstasy. Two of them have often come together, but the three never"). ${ }^{101}$ The third and last of the deceased friends to appear is "old George Pollexfen," "Having grown sluggish and contemplative" (1. 40), whose passion and "muscular youth well known to Uayo men/ For horsemanship" (11. 34-5) have declined into the dissipation of age that Jonson called "the dead sea of 11fe." Gregory, as Kermode reminds us, is primarily 
treated as a painter; and as such, he symbolizes

the artist who had escaped into action, a delighted escape from a typical oruel dilemma imposed by the nature of the artist and exacerbated by moderm decadences and this escape was made by a way which other divided men had not found, or had risked.102

Among the other men, Kermode writes, "[Fionel] Johnson [wag] the formal antithesis of Gregory in his solution."103 Gregory's stunning escape into the life of action, which"took [Yeats'g] heart for speech," enabled him to achieve the ideal of personal life, aristocratic sprezzatura, "tragic joy," or Unity of Being; the last oight lines of "An Irish Airman Foresees His Death" illustrates this better, perhape, than stanza VIII with its depiotion of Gregory's foolhardy horsemanship:

Nor law, nor duty bade me fight, Nor public men, nor cheering crowds, A lonely impulse of delight Drove to this tumult in the clouds; I balanced all, brought all to mind, The years to come seemed waste of breath, A waste of breath the jears behind I balance with this life, this death.

This "tragic joy" we are now familiar with in Yeats. But something like a wish for Unity of Being or joy, the full delight of the Sidneian hero, seems to be suggested as Jonson makes a noteworthy appearance in his elegy:

The Counter-turne

Hee leap'd the present age,

Possegt with holy rage, To see that bright eternall Day 
Of which wo Priests, and Pbets say

Such truthe as we oxpeot for happy men, And there he lives with memorie; and Ben

\section{The Stand}

Johnson, who sung this of him, e're he vent

Himselfe to rest,

Or taste a part of that full joy he meant

To have exprest,

In this bright Asterisme.

(11. 79-89)

Certainly, Jonson's intended meaning is not unorthodox, like Yeats's. Jonson's tragic hero, like Yeats's, is "a Souldier," "A perfect Patriot, and a noble friend" and "most a vertuous Sonne"; but he is not, like Gregory, an artist. In Yeats's meditation, Kermode writes,

It is as an artist-though with the old aristocratic sprezzatura-escaping from the penalties of imagination, that the dead man is presented to us. This is a symbolic figure vio lently abstracted from life, existing in some pattern of the poet's mind..... Gregory escaped from art, and his escape became an image, a new thing named, a new truth, for an artist who did not escape but stood his course in a darkening and increasingly hostile world. 104

The most frequent theme of Yeats's meditation, in the occasional poems which follow, is the possibility of heppiness, order, innocence, custom, ceremony-aristocratic and Jonsonian virtues allretrieved in the face of impending chaos.

-..all hatred driven hence, The soul recovers radical innocence And leams at last that it is self-delighting.... ("A Prayer for my Daughter," 11. 65-7)

The hero recovers but the instant of his lifetime, makes his stand to build "B house/ Where all's accustomed, ceremonious" ("A Prayer 
...," 11. 73-4), fathers a family and gambles against the universal decline of civilization that his issue, now more than just a book, will flourish awhile before chaos restores all to "roofless ruin." In Michael Robartes and the Dancer (1921), we see the birth of a "terrible beauty" in the poems "Easter 1916" and "The Second Coming."

...twenty centuries of stony sleep

Were vexed to nightmare by a rocking cradle, And what rough beast, its hour come round at last, Slouches towards Bethlehem to be born?

$$
\text { ("Second Coming," 11. 19-22) }
$$

Appropriately, the important sister poem to "The Second Coming," "A Prayer for my Daughter," is occasioned by a storn during which the poet's infant daughter "sleeps on," "half-hid/ Under this cradlehood and coverlid" (1. 1-3). The protective father walks and prays, and his prayer, the meditation of a mind which "has dried up of late" -itself a familiar symptom of the melancholy artist or scholar of the Renaissance-, Is the poem. And the poem describes his means of escaping the "blood-dimmed tide" loosed upon the world in the vision of "The Second Coming," where "The ceremony of innocence is drowned" (1. 6): an escape through generation and genius, as in "Pardon, old fathers," in "blood," in the future of his child and the unknom generations of his house, an axistocratic if momentary flourish.

Bergl Rowland, in "The Other Father in Yeats's 'A Prayer for My Daughter, "' recognizes in the poem similarities to Coleridge's "Ver Perpetuum," "Frost at Mianight" and "Dejections An Ode."105 Others, however, hear a significant Jonsonian ring; and, as a result, 
It is thought that Yeats's bringing together of these two tones, that of Jonson and that of Coleridge, is the great achievement of Yeats's occasional verse. In "Yeats and the Occasional Poems 'Easter 1916,'" Marjorie Perloff writes that Yeats's occasional verse "is, in fact, a fusion of these two modes: the Jonsonian verse epistle and the Coleridgean conversation poem.... the fusion is, moreover, one that Yeats very nearly invented." 106 Taken as types, Jonson represents what is classical or traditional, public and formal, while Coleridge represents what is romantic, private and subjective. What is distinctively Jonsonian about this particular poem has, as mentioned before, been addressed by Donald Davie, who refers us to "the explicit invocation of Ben Jonson" in the Epilogue of Respongibilities, where the line "Being but a part of ancient ceremony" asgumes an importent plaoe in the vision of "The Second Coming," where "The ceremony of innocence is drowned," and in its anti-vision of "A Prayer ...," where it is hoped in the last stanzas

\footnotetext{
... may her bridegroom bring her to a house Where all's acoustomed, ceremonious; For arrogance and hatred are the wares Peddled in the thoroughfares. How but in oustom and in ceremony Are innocence and beauty born? Ceremony's a name for the rich horn, And custom for the spreading laurel tree.
}

In "Yeats, The Master of a Trade," Davie refers us especially to those last two lines, about which be writess

The images here-of the cornucopia, the horn of plenty, and of the laurel tree-are the most hackneyed images imaginable. And that is only to say, the most traditional. These lines could have been written by any good poet writing in any West- 
ern European language at any time from the sixteenth century to the present day. 107

In his essay "Michael Robartes and the Danoer," however, Davie zeroes in on two such writers of the English Renaissance: Jonson and Donne. And Davie finds Jonson to be the one "who presides over "Prayer for My Daughter"'; for Jonson is regarded as superior to Donne in the genre of the verse-epistle, and the "Horn of Plenty," repeated in Yeats's poem on two other occasions (11. 32 and 60), with its reference to classicel mythology, not only represents Yeats's "unembarrassed" use of a hackneyed-or traditional-literary property, but it compares with Jonson's use of classical myths. 108 On this topio, Nichols is in agreement with Davie. In The Poetry of Ben Jonson, Nichols explains,

Poets still go without ostentation to the pagan myths to illustrate their thought..... It is not 'confusion' we find in either Jonson or Yeats, but simply an extension of the meaning in the myth till it becomes a sort of metaphor. 109

Similarly, Davie says that Yeats, like Jonson, "naturalized" classical material to his own particular landscape and for his own pur poses-

classical references can be homely while still exalted...Jonson's classicel orudition worked in just this way-towards a habituation, a complete translation of ancient Greece and Rome. The same neo-classicism at its Jonsonian best uses 'radical' -'radical innocence'-to link through its Latin etymology with the sustained imagery from vegetation. 110

Interestingly, Yeats's use of the "Horn of Plenty," which sets up in opposition the bride and groom of the last stanza beside the mar- 
riage of Maude Gonne and John MacBride (stanzas 4 and 8), Nichols associates with a couplet from Jonson's "An Epistle to a Friend, to perswade him to the Warres" (Under-wood, XV):

The Servant of the Serving-woman, in scorne, Ne're came to taste the plenteous Mariage-horne.

(11. 99-100)

While Nichols goes no further than observing "a Yeatsian ring" in the couplet, he does so with emphasis: "The very feel of this reminds us of Yeats, while 'the plenteous Mariage-horne' can hardly fail to bring 'A Prayer for my Daughter' to mind." 111 In Yeats, "Ceremony's a name for the rich horn" (1. 79).

In the gixth stanza of "A Prayer....," we find an exposition of that important tree image, the symbol of "custom" (1. 80) or "rootedness" which is of central aignificance later in Yeats's Great House poems, "Coole Park, 1929" and "Coole Park and Ballylee, 1931."

\footnotetext{
May she become a flourlshing hidden tree That all her thoughts may like the linnet be, And have no business but dispensing round Their megnenimities of sound, Nor but in merriment begin a chase, Nor but in merriment a quarrel. 0 may she live like some green laurel Rooted in one dear perpetual place.
}

Such an idea of "rootedness" opposing change is aristocratic and, McAlindon asserts, was a contribution from Yeats's reading of Ben Jonson. As McAlindon observes, "Yeats refers to his heavily mythologized Jonsonian friend," John Synge, as "that rooted man" in "The Municipal Gallery Revisited" (VII). 112 Similarly, we observe the metaphor of the family tree and "rootedness" in the poetry of Jonson: 
And raise a noble stemme, to giue the fame, To CLIFTON's bloud, that is deny'd their name. Grow, grow, faire tree, and as thy branches shoote, Heare, what the Muses sing about thy roote....

("Epistle. To Katherine, Lady Arbigny," The Forrest, XIII, 97-100)

Such Notes are vertuous men! they live as fast As they are high; are rooted, and will last. They need no stilts, nor rise upon their toes....

("An Epistle to Sir Edward Sacville, now Earle of Dorset," Under-wood, XIII, 143-5)

0 how will then our Court be pleas'd, To see great Charles of Travaile eas'd, When he beholds a eraft of his owne hand, Shoot up an Olive fruitful, faire, To be a shadow to his Heire,

And both a strength, and Beautie to his Iand:

("To the Right honble Hierome, I. Weston. An Ode Eratulatorie..." Under-wood, IXXIV, 25-30)

... Nature, or the Iater Ayre

Gave two such Houses as NORTHUNBERIAND, And STANLEY, to the which shee was Co-heire. Speake it, you bold PENATES, you that stand At either Stemme, and know the veines of good Run from your rootes Tell, testifie the grand Meeting of Graces, that so swell'd the flood of vertues in her, as, in short, shee grew The wonder of her Sexe, and of your Blood....

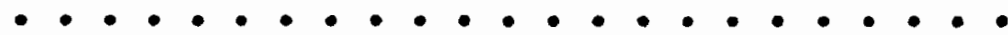

Shee had a mind as calme, as shee was faire; Not tost or troubled with light Lady-aires But, kept an oven gate, as some streight tree Mov'd by the wind, so comely moved she.

("Euphemes or, The Faire Fame left to Posteritio Of that truly-noble Iady, the Iady VENETIA DIGBY ...," Under-wood, IXXXIV, Part II, 4-12 and Part IX, $263-6) 113$

In Yoats's two later poems, "Coole Park, 1929" and "Coole Park and Ballylee, 1931," the "rootednese" or permanence of the houses of Gregory and of Yeats faces the same opposition as the permanence of custom the poet meditates on in "A Prajer for my Daughter." "Pas- 
sionate intensity," which was associated with the characters of Jonson by Swinburne, Symonds and Yeats and whioh was associated by Yeats with the personalities of a few admired companions, is a characteristic of "the worst" by the time the Second Coming arrives; and when that time comes, not only is innocence dromed, but a profound reversal of values takes place. Anarchy replaces custom and ceremony; the best are indifferent, "while the worst/ Are full of passionate intensity" ("Second Coming," 11. 7-8). Fundamentally, this is the imminent "darkening flood" which threatens with extinction the houses of Yeats and Gregory in these two later poems. In "Coole Park, 1929," we have the tree symbol attached to Lady Gregory, "that laurelled head," but the "aged woman and her house,/ A sycamore and lime-tree lost in night" (11. 2-3), subjects of meditation, represent that momentary flourish that the poet must eventually concede to a prevailing set of vegetation images-"nettles... on a shapeless mound/ And saplings [which] root among broken stone" (11. 27-8). In "Coole Park and Ballylee, 1931," we have a similar degeneration.

Upon the border of that lake's a wood Now all dry sticks under a wintry sun, And in a copse of beeches there I stood, For Nature's pulled her tragic buskin on And all the rant's a mirror of my mood: At sudden thunder of the mounting swan I turned about and looked where branches break The glittering reaches of the flooded lake.

$$
\text { (11. 9-16) }
$$

The "darkening flood" from line 48, however, is more portentous of destruction and evil than the quiet decay and peaceful overgrowth depicted in the previous poem. Lady Gregory, not presented in the poem 
but as the "Sound of a stick upon the floor" (1. 25), in her house, represents a way of life already half-faded from the world.

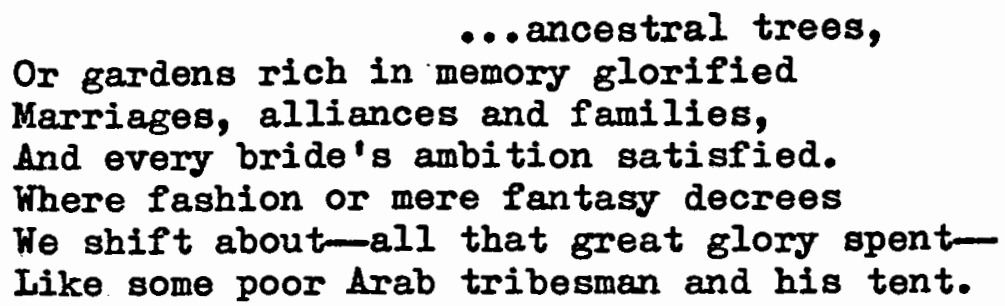

(11. 34-40)

The "Arab tribesman and his tent" signify a culture which ceases to be "rooted" and civilized. Opposite that, we have "ancestral trees" and houses, "Marriages, alliances and families," "every bride's ambition satisfied," which should be more than sufficient reminder of the final stanza of "A Prayer for my Daughter."

More than the symbol of a family, however, lady Gregory's house at Coole Park stands for the kind of noble hospitality that Ben Jonson similarly honored in his celebration of the Sidney family in "To Penshurst." In Yeats's "Coole Park, 1929," the poet's meditation "upon a swallow's flight,/ Upon an aged woman and her house,/ A sycamore and lime-tree lost in night" (11. 1-3) carries his memory to the thought of "Great works constructed there in nature's spite" (1. 5) and to the cultivated company of Hyde, Synge, Shawe-Taylor and Lane. Iike that welcome patronage Jonson acknowledged from the Sidneys at Penshurst ("Here no man tells my cups.... all is there;/ As if thou, then, wert mine, or I raign'd here"), this assorted troop of "traveller, scholar, poet" was assured of finding at Coole "pride established in humility,/ A scene well set and excellent company" 
(11. 15-16). The movement from the meditated objects of two particular trees to the revery of a past "dance-like glory" involving an invocation of these names cannot help suggesting the famous signem ture tree on the Coole estate which bears the engraved initials of such company. If Yeats had this suggestion in mind, then it parallels some of the early lines of "To Penshurst," where Jonson writes of a great tree planted at Penshurst on the day of Sir Philip's birth in 1554 :

\begin{abstract}
That taller tree, which of a nut was set At his great birth, where all the Muses met. There, in the writhed barke, are cut the names of many a Sylvane, taken with his flames.
\end{abstract}

(11. 13-16)

The "dance-like glory" of the poets and the appearance of the "Muse" in Yeats's poem creates an antique air which complements the "ancestral trees," "Iraditional sanctity and loveliness" (1. 42) of "Coole Park and Ballyloe, 1931" as well as the Arcadian landscape of "Penshurst." Charles Tomlinson, in "Yeats and the Practising Poet," writes?

Yeats revirifies for us the language of courtesy that we know from the seventeenth century. His poems on great houses, and on their ruin, stand at the end of the line of the English country-house poem, descendants of Ben Jonson's 'To Penshurst', of Carew's 'To Wy Friend G. N., from Wrest', Herrick's 'Panegerick to Sir Lewis Pemberton', Marvell's 'Appleton House' and the fourth epistle of Pope's moral essays. The language of these poems is the language of tact and the language of power....114 


\section{PARTING IMAGES}

In these later poems of The Winding Stair (1933) through Last Poems (1936-9), Yeats's language frequently resembles that of Elizabethan and Jacobean poets. A debt to Donne has already been noted here, though there are certain short-comings in the comparison: Yeats's poetry often seems exciting, as Donne's is often exciting, for our sense of witnessing the action of an intelligent man's thought; but, as George Saul writes, Yeats

looks something of an alien when compared with the 'metaphysfoals' of tradition: he is not gnarled; he is brilliantly rational in metaphor, never strained or far-fetched; he is subtle without being intellectually oute. 115

Yeats uses phrases and vocabulary in these poems which are directly attributable to bis reading of the Renaissance poets. For instance, in the line "Heroio reverie mocked by clom and knave" (1.27) from "A Bronze Head," we are reminded not only of those "knaves" and "dolts" from the Green Helmet and Responsibilities, but "clown" here seems to have the particular meaning of peasant or common person that we often find in Jonson, for example, in "To Penshurst" (1.48) and Under-wood, LXIV (1. 19), quoted above. Similarly, Yeats's "A Drunken Man's Praise of Sobriety," with lines like "Come swish around, my pretty punk" and "A mermeid, not a punk," has its definite Jonsonian ring while exhibiting one of the most characteristic masks of the Last Poems, that of Yeats's wild old wioked man. Henn has noticed "several memories of Jonson" In the vicinity of the poem "Parting," in A Woman Young and Old, where he observes that the phrase "the 
household spies (a strange expression) is in Volpone, iii, 6."116 Except for an inaccuracy in the citation (which should be Volpone, III, ii, 177), Henn's observation 1s helpful, for we find the phrase embedded in Volpone's seduction song, "Come, my Celia, let us prove," a poem Yeats undoubtedly knew, which also appears in The Forrest (v, "Song. To Celia."). Adding further comment on this phrase "household spies," Jon Stallworthy, in Between the Lines, notes its persistence from the earliest drafts and suggests that it was "either assimilated from [Yeats's] reading of Donne's 'Twelfth Elegy,'" also called "His Parting from Her," where the phrase occurs in line 4l, "or, less probably, of Ben Jonson's Volpone, Act III, scene v"117 (also an incorrect reference to a non-existent scene). A further observation of a possible "memory of Jonson" is made by Henn, who finds a relation between a picture image of "Berenico's burning hair" (1. 8) from "Her Dream" (Words for Music Perhaps, XIII, in the Crazy Jane cycle) and a similar presentation in Jonson's line, "Who made a lampe of Berenice's hayre?" (1. 61), from "Epistle. To Elizabeth Countesse of Rutland" (The Forrest, XII). And both J. R. Mulryne, In "The 'Last Poems, " 118 and Denis Donoghue, in William Butler Yeats ${ }^{119}$ have noted an "oblique reference" to Jonson's phrase from The Poetaster, "rammed with Iife," in Yeats's "To Dorothy Wellesley" in Last Poems; there, "Rammed full/ of that sensuous silence of the night" (11. 5-6), one climbs to one's "chamber full of books" and awaits the visitation of the immortal-in-memory, inspiring, passionate dead-" that great family/ Some ancient famous authors misrepresent,/ The Proud Furies..." (11. 14-16). 
But the most intriguing possibility of a borrowing from Jonson in Yeats's last work occurs in the first entry of Last Poems, "The Gyres," which openss

The Gyres! the gyres! Old Rocky Face, look forth....

An invocation of Jonson in this poem, as he appears in "My Picture Left in Scotland"-a poem Yeats may have known either from The Underwood (IX) or from Conversations with William Drummond of Hawthornden, where, aside from a certain madrigal, it is the only poem quoted in full-represents a choice by Yeats that fits comfortably into several movements now culminating in the Last Poems. As in the "Charis" pieces, Jonson's love melancholy is humorously depicteds

\section{Oh, but my conscious feares, That flie my thoughts betweene, Tell me that she hath seene My hundreds of gray haires, Told seven and fortie yeares. Read so much wast, as she cannot imbrace My mountaine belly, and my rockie face,} And all these through her eyes, have stopt her eares. (11. $11-18$ )

The extent to which Jonson presides over Yeats's "Old Rocky Face" is indeed an unsettled question. While J. R. Mulryne firgt suggested the relationship in 1965, saying that "Rocky Face" "might have been prompted by a reading of Ben Jonson's 'My Picture Left in Scotland, "'120 Jon Stallworthy writes, in Vision and Revision in Yeats's Poems (1969), that it is now "generally agreed... that an echo or recollection of the phrase 'rockie face' in Ben Jonson's poem..."121 is a part of a compounded mask of the persona-and Stallworthy makes this assertion with 
no other apparent support than Mulxyno's "might have been." It is generally agreed that the cave dwelling hermit of "The Gyres," as Staliworthy points out, "is a...development of the hermit upon Mount Meru"122 "Caverned in night under the drifted snow" ("Meru," 1. 10) and is clearly related to the "Rocky Voice" of "Man and the Echo." But it is not clear or "generally agreed"-or generally known eventhat a mask of Jonson's "rockie face" figured into the composition of "The Gyres" or any other poem. Jonson's self-portrait may be accounted as a fourth or fifth element in that poem-among the Delphic oracle, the Oriental ascetic, Shelley's Ahasuerus (the cavedwelling Jew in Hellas) and even a stone head placed high on the outside of Yeats's tower-but the association cannot be supported in "The Man and the Echo," for instance, and has yet to be adequateIy explained in "The Gyres."

It has been suggested that the "I" in "The Gyres" and "Rocky Face" are one and the same. And it has even been suggested that they are both Yeats, Yeats in his mask of old age. Or, like that "reedthroated whisperer" from the Epilogue of Responsibilities, "Rocky Face". may be thought to be the new face and the new voice of the Muse: a tomb-haunter here, as once its ghostly significance ("A clear artioulation in the air") had the man of Aroadia and the comfort of en ancient roof it is now perhaps more nearly like the "Proud Furies" in "To Dorothy Wellesley," where an oblique quotation of Jonson is also given. As the Kuse, Daimon or some "passionate dead," "Rocky Face" might even call up the memory of Yeats's war-gods from "The Magi"_-"their enoient faces like rain-beaten stones" (1.4). But 
an important detail should be noticed early in the first few Iines of "The Gyres:" "Rocky Face" is essentially an emblem, a "picture Image" as Henn would call it, of Melancholy in the old-fashioned Elizabethan sense of the word. Yeats demonstrated his familiarity with the traditional literary pictures of Melancholy throughout his poetry; it is shown to be of various types and ranges from "The Sad Shepherd," with his inexplicable sorrow; to "Adam's Curse," where the quest for a changeless love and a high poetic beauty has left the poet in the poem "As weary-hearted as that hollow moon"; to the poems of The Green Helmet and Responsibilities, where the poetpersona complains that "The fascination of what's difficult/ Has dried the sap out of my veins, and rent/ Spontaneous joy and natural content/ Out of my heart"; to the "hollow face" and "stony face" of Dante in "Ego Dominus Tuus"; to "A Prayer for my Daughter," where "My mind, because the minds that I loved,/ The sort of beauty that I have approved,/ Prosper but little, has dried up of late"; to the Last Poems. There, in "The Municipal Gallery Revisited," for instance, John Synge is remembered as "that rooted man" with "a grave deep face"; thrown against the scene of "this filthy modern tide" in "The Statues," we find "Hamlet thin from eating flies... Empty eyeballs" which know "That knowledge increases unreality", and in "The Gyres," Rocky Face is told that "Things thought too long can be no longer thought,/ For Beauty dies of beauty, worth of worth,/...ancient lineaments are blotted out" (11. 2-4). The Melanoholy of Last Poems is of the type that belongs to elder soholar-poets who have burnt up their minds with too much toil and care for responsibilities dismissed by the world. A 
suggestion of Jonson here has a mollifying effect on the terror inherent in the vieion of apocalypses his love melancholy, like the lustful passions of the old man in the Last Poems, is always presented as just a little ridiculous. A suggestion of Jonson is also complementary to the Shakespearean scene of the next poem, "Iapis Lazuli," where Hamlet and Lear are gay. As Rocky Face is bid "look on but laugh in tragic joy" (1. 8), the melancholy character he represents is very different, though part of the same tradition, from the care worn visage of Spenser's "rugged forehead" (Faerie Queene, Bk. IV, Proem, st. i), an image that impressed Yeats (see Essays, pp. 369-70, and The Autobiography, p. 208). Yeats read Burton's Anatomy of Melancholy and quoted a long passage from it in On the Boiler, a colleotion of thoughts written shortly before his death. 123 And it may be possible that when he sought to give his cavern dweller in "The Gyres" a proper title, he remembered Jonson for the picture of melancholy Jonson had presented of himself in such works of Yeats's acquaintance as "An Ode (To himselfe)," from The New Inn, and those two possible sources for Yeats's quotation of Jonson in the Epilogue of Responsibilities, "An Ode. To Himselfe" (Under-wood, XXIII) and "To the Reader," an "apologeticall Dialogue" ending Poetaster, where "Rocky Face" (in early drafts "Cavern Face") may have been suggested by the likes of the following:

I, that spend half my nights, and all my dayes, Here in a cell, to get a darke, pale face, To come forth worth the luy, or the bayes.... (11. 233-5) 
If "Rocky Faoe" is, indeed, Youts himself in the poem, then Jonson may have interested him as a master of personal epithet. Jonson's poetry is rich with such personal glimpses of the poet as is found in "My Picture Ieft in Scotland."

But to end this discussion of "The Gyres," "tragic joy" of course should be our signal that this is essentially a poem of affirmation. Poetry, we should remind ourselves, "calls out in joy,/ Being the scattering hand, the bursting pod,/ The victim's joy among the holy flame,/ God's laughter at the shattering of the world" (King's Threshold, 11. 186-9). "Hysterioa pessio," which is named in "A Bronze Head" and "Parnell's Funeral" (whose "Great Comedian's tomb" and "painted stege" may have some relation to the "painted forms or boxes of make-up/ In ancient tombs" in the "Rocky Face" poem and "Lapio Lazuli"), is manifest in "The Gyres," where "Irram tional streams of blood are straining earth..." (1. 5). But "Rocky Face," like Robert Gregory and his mother, like Ben Jonson, symbolizes those things which oppose enarchy. The tide, we see, is about to turn. The final twisted sentence, unraveled, affirms this, "Those that Rocky Face holds dear,/ Iovers of horses and women, shall... disinter/ The workmen, noble and saint, and all things run/ on that unfashionable gyre again."

\section{SUMMARY AND CONCIUSIONS}

E. Engelberg has noted the frequency with which the phrase "What matter?" appears in Yeats's Last Poems. It is the important question of "The Gyres," where it was even used as the title of an 
early draft. But, in "The New Generation and the Acceptance of Yeats," Engelberg cautions us,

it bears no ironic overtones, no tired sigh of ennui or despair. At best it is philosophic detechment; at worat hysterias but it is never absolvement. Richard Ellmann has called it Yeats's 'affirmative capacity' and I cen think of no better phrase. 124

What Yeats's poetry finally represents is the poet's détente with life and death. And the poet's recourse to tradition was a means which partly provided for this easing of tensions. Those things which are radically "romantic" and customarily "classic," egocentric and social-oriented, creative and imitative, are opposed in perfect equilibrium, yet are organically bonded like Hic and Ille, anima hominis and anime mundi in the individual soul which transcends a single life and death. Tradition-custom, ceremony and courtesy, abstractions Yeats adhered, to at a time when his poetry was becoming more and more concrete-provides the poet with a momentary security, a flourlsh, within which time he may create something of lasting beauty, something permanent, the anti-self or mask of world decadence.

Yeats's first move into the world of action in poetry is noted by his recourse to models like Jonson, Byron and Landor, poets who have given a powerful masculine voice to their poetry and who provided fine satiric examples with which to oppose the coarse conduct of the soul of the world. Yeats looked to the Elizabethans and Jacobeans for the "passionate syntax" of the active man's speech; but he elso looked for something else, just as useful to him, their values, their form, their love for "poetic oratory, and... audacious 
metaphors"-something permanent and aristocratic, something to be played to the balconies and not to the low floor. In The Green Helmet and Responsibilities, as Davie says, Yeats

envisaged himself at this time as a specially privileged retainer of such a noble house [as Lady Gregory's], the poet maintained by the family to serve them by his poetry just as their groom and chambermeids served them in humbler ways. This was the relationship between poet and patron which Ben Jonson celebrated in many of his verse-epistles, and which he preferred to being patronized by the public at large, just as Yeats preferred it after his disappointment with the Abbey Theatre audiences. 125

The next stage, then, in the derelopment of Yeats's poetry to which his reading of Jonson contributed, is marked by the introduction of a series of long poems affirming or celebrating some meditated ideal-or its loss-or worthy individuel. The poems of the Wild Swans at Coole, The Tower and The Winding Stair, though on the surface set at the houses of Gregory and Yeats, on another level are really set at Penshurst again. The pootic form that Yeats champions there is the verse-epistle, which, according to Perloff, Yeats translated for his own purposes from the traditional mode that Jonson's occasional poetry represents and from the romantic mode represented by the Coleridgean conversation poem. And the fusion of these two antithetical modes-public song and private thought-produces some of Yeats's greatest masterpieces, including "Sailing to Byzantium."

Yeats's meditation on the imminent ruin of "anoient houseg" in The Tower and The Winding Stair-"We were the last romantics..." ("Coole Park and Ballylee, 1931," 1. 41)-turns to the meditation of "ancient tombs" in Last Poems; the Great House poem becomes almost 
the Great Tomb poem, starting with "The Gyres" (whose hysterical vision was arduously wrought in the noble ottava rima stanza, same as "Sailing to Byzantium") and ending with "The Black Tower" and "Under Ben Bulben." The substance of Yeats's poetic vision comes full circle while the technical accomplishment of the poet moves steadily forward in a straight line. The last Arcadians rattle their swords in their tombs-men and women of a past time and an older order, "workmen, noble and saint"-while the mythmaker distinguishes himself as a modern poet so accomplished that his technical skill is virtually inimitable.

On this last point, finaliy, we note that much has been said about Yeats's accomplishments as a poet and the very hard work that went into his art. Robert Beum, in The Poetic Art of William Butler Yeats, places Yeats in a larger frame of poetic tradition, one in which Yeats would have undoubtedly approved, in a view of poetry and poets

thet has prevailed not only in England and Ireland but all the round earth's imagined cormers, a view rarely challenged until recent times-times, interestingly enough, of massive intellectual confusion and social fragmentation. It is a view ["... of the 'devil of a lot of trouble' it cost him to cast his material into verse, of the agony of working all day and producing nothing final, or merely a sequence of four or five completed lines..."1] that has accommodated poets as different as Jonson and Keats, Chaucer and Shelley, Vergil and Milton, Camolns and Sung YU. One must get it in plain sight or not see Yeats in the right perspective.126

Furthermore, Nichols refers to the "good company" which Yeats and Jonson kept as poets who pounded out their verse from prose drafts Virgil, Pope, Goldsmith, Coleridge, Tennyson, Browning and Rossetti 
(the list, hardly complete, is meant to illustrate the extreme range which exists). Donald Davie, however, in "Yeats, The Master of a Trade," is perhaps the only writer to compare Yeats with Jonson in the discussion of Yeats's "influence" on other writers, particularly later generations of writers. What Davie is concerned with is "technical influence," what a poet is more likely to be interested in than a "commentator"-"cold-blooded 'know-how', having to do with tricks of the trade and rules of thumb-such as a note on how it's usually better to rhyme verb with noun than verb with verb." 127 Davie's contention is that most often second-rate poets are of more use to other poets and represent the body of tradition better than are its "central poets." Jonson is the exception to this rule and, as such, is opposed to the late Yeats; Jonson is "one of those very rare great poets whose influence is in no way vitiated by the very fact of their greatness."128 Those "hackneyed" and "traditional" images of the middle Yeats, such as the "Horn of Plenty" and the "spreading laurel tree" in "A Prayer for my Daughter," are profitable instruction for the young poet, Davie writes, for

backneyed, conventional images are in themselves no worse, and in fact are probably better for most purposes, than unprecedented imazes. The young poet can learn, in faot, that all his efforts to be above all original, distinctive, himself and no one else-all these exertione are probably wasted labour. 129

The influence of Jonson on his contemporaries and near-contemporaries is well-known. But Davie believes that, taken as a whole, Yeats is not like Ben Jonson, a genius whose example to other poets is not impeded by his own distinctive roice. Still, when considering the 
middle Yeats, perhaps then we wlll find that these two poets resemble each other.

Yeats' [8ic.] influence has not been universally benefioial. His greatest poems... have tended to lead later poets astray. For these are poems in which Yeats takes liberties which hardly anyone else can afford to take; this is what makes these poems glorious, it is also what makes them dangerous. It's the slightly earlier collections-above all, The Wild Swans at Coole and Michael Robartes and the Dancer-which contain the poems which are models of poetic diction. And of these at least I believe we can say that their influence 'has always heightened and purified the art of others'. And it's for the sake of these poems by Yeats that all of us who write with deliberation are now his debtors. 130

Marjorie Perloff's claim should make an adjustment in Davie's theory; for she sees, in the new type of "confessional" poetry written by Robert Iowell, W. D. Snodgrass, Sylvia Plath, Anne Sexton and John Berryman, the influence of Yeats's greatest poetic accomplishment still strong in a younger generation of poets. "At its worst," she writes,

the new 'confessional' poetry becomes sheer sociological documentation on the one hand, or the raw material for one individual's autobiography on the other. At its best, however, the 'confessional' mode, which is quite simply the occasional mode of Yeats in a new dress, is no more personal than that of Coleridge's conversation poems, no more documentary than that of Ben Jonson's Epistle Answering to One That Asked to be Sealed of the Tribe of Ben.131

"Pradition," as Eliot wrote, "is a matter of much wider significance. It cannot be inherited, and if you want it you must obtain it by great labour." 132 This was certainly true of Yeats. Yeats's success at modernizing his verse came largely as a result of his appreciation of oertain dead poets of the past and his determination 
to do what they had done. While a product of his own particular time, he could trace his lineage to the anoients. While taking a particular interest in writers of the English Renaissance, he saw that he belonged to a tribe of men, poets, deliberate writers of personality and imagination, which linked the present age to the mythical past in an unbroken chain. The road from Seanchan and Orpheus to Homer and Chaucer, to Jonson, Shakespeare, Spenser and Donne, to Swift, to Blake and Shelley, and to Yeats, is uneven and not wi thout its bends and obstacles. The poet has always to fight the distractions imposed upon him by his great enemy, the world, because the poet, more than most men, is divine. The antagonism between the poet and the world, reflected in miniature by the war that takes place inside the poet himself, is also implicit in the effect that Yeats's reading of Jonson had on his poetry. Rhetoric, as Yeats defines it, is the antagonism between the poet and his world, while poetry is the antagonism between the poet and himself. Jonson's great contribution to Yeats's style of poetry is characteristio of this dichotomy. Above all, style, "the sensible impressions of the mind,.... deliberate shaping of all things," whether used as a rhetorical weapon or a self-saving convenience to "Poeticall Rapture," is the only escape from "that raving slut/ Who keeps the till," "Mistress Commodity." Jonson, as a writer of "passionate syntax" and personality, produced a powerful body of work which exemplified for Yeats both the language of courtesy and the language of scorm. 
1 George T. Wright, The Poet in the Poem? The Personae of Eliot, Yeats, and Pound Berkeley and Ios Angeles: Univ. of CaIifornia Press, 1960), p. 97.

2 Ibid., p. 89.

3 Ibid., p. 97.

4 Ibid.

5 Ibid., p. 99.

6 Ibid.

7 Russell K. Alspach, "Yeats's First Two Published Poems," Modern Ianguage Notes, Vol. LVIII, No. 7 (Nov., 1943), pp. 555-7.

8 See George Brandon Saul, Prolegomena to the Study of Yeats's Poems (Philadelphia: Univ. of Pennsylvania Press, 1957), pp. 43-4.

9 Wright, The Poet in the Poem, p. 101.

10 H. B. Yeats, The Letters of W. B. Yeats, Allan Hade, ed. (New York: Macmillan Publishing Co., Inc., 1955), p. 434.

11 Wright, The Poet in the Poem, p. 99.

12 K. B. Yeats, Essays and Introductions (New York: Collier Books, 1973), p. 110.

13 Ibid., pp. 377-8.

14 Ibid., pp. 252-3.

15 See T. McAlindon, "Yeats and the English Renaissance," PMIA, Vol. LXXXII, No. 2 (May, 1967), pp. 157-8.

16 Yeats, Essays and Introductions, p. 253.

17 Ibid. 
18 B. Rajan, "Yeats and the Renaissance," Nosaio, Vol. 5, No. 4 (Summer, 1972), p. 114 .

19 Charles Altieri, "From a Comic to a Pragic Sense of Language in Yeats's Mature Pootry," Modern Language Quarterly, Vol. 33, No.. 2 (June, 1972), P. 159.

20 John E. Unterecker, A Reader's Guide to Hilliam Butler Yeate (New Yorks Noonday Press, 1954), p. 103.

21 Denis Donoghue, William Butler Yeats (New Yorks The Viking Press, 1971), p. 90.

22

Wright, The Poet in the Poem, P. 104.

23 Muriel c. Bradbrook, "Yeats and Elizabethan Love Poetry," The Dublin Magazine, Vol. 4, No. 2 (Summer, 1965), P. 41.

24 Cf. Ben Jonson, The Vnder-wood in Ben Jonson, Vol. VIII, C. H. Herford, Percy and Evelyn Simpson, ods. (Oxfords At the Clarendon Press, 1954), p. 188.

25 Wright, The Poet in the Poem, p. 105.

26 William York Tindall, "W. B. Yeats," Columbia Essays on Modern Writers (New York \& London, Columbia Univ. Press, 1966), p. 16.

27 William M. Carpenter, "The Green Helmet Poems and Yeats's My th of the Renaissance," Modern Philology, Vol. 67, No. I (Augrast, 1969), p. 54 .

28 Tindall, "W. B. Yeats," p. 16.

29 McAlindon, "Yeats and the Englisb Renaissance," p. 167.

30 J. G. Nichols, The Poetry of Ben Jonson (New Yorks Barnes \& Noble, Inc., 1969), pp. 161-2.

31 W. B. Yeats, Explorations (New Yorks Collier Books, 1973), p. 81 .

32 S. B. Bushrui, Yeats's Verse-Plays: The Revisions, 19001910 (London: Oxford Unt7. Press, 1965, 1965), p. 208n. 
33 Frank C. Nelick, "Yeats, Bullen, and the Irish Drama," Moderm Drama, I (1958), pp. 196-202.

34

Ibid., p. 298.

35 Ibid., p. 197.

36 Ibid., p. 198.

37 McAlindon, "Yeats and the English Renaissance," p. 164.

38 L. C. Knights, "Poetry and Social Criticisme The Work of W. B. Yeats," Explorations; Essays in Criticism Mainly on the Seventeenth Century (New York: University Press, 1964), pp. 190-1.

39 McAlindon, "Yeats and the English Renaissance," p. 166.

40 T. R. Henn, "'The Green Helmet' and 'Responsibilities, "' An Honoured Guest, Denis Donoghue and J. R. Nulryne, eds. (Iondons Edward Arnold, Ltd., 1965), p. 38.

41 K. L. Goodwin, The Influence of Ezre Pound (Iondon: Oxford Univ. Press, 1966), pp. 85 and 92.

42 T. R. Henn, The Lonely Tower; Studies in the Poetry of

W. B. Yeats (Iondon: Methuen \& Co., Ltd., 1950), p. 92.

43 Colin Meir, Ballads and Songs of $W$. B. Yeats: The AngloIrish Herltage in Subject and Style (New York: Barnes \& Noble, 1974), p. 105 .

44 Ibid., p. 104.

45 Yeats, Letters, pp. 709-10; ibid.

46 William H. Pritchard, "The Uses of Yeats's Pootry," W. B. Yeats: A Critical Anthology, William H. Pritchard, od. (Hidalesez, Eng.: Penguin, 1972), p. 89.

47 Ben Jonson, Epigrammes in Ben Jonson, Vol. VIII, Herford and Simpson, ods., p. 27 .

48 Ibid., p. 66. 
49 Edward B. Partridge, The Broken Compass? A Study of the Major Comedies of Ben Jonson (New York? Columbia Univ. Press, 1958), p. 35. $612,664-5$.

50 Yeats, Explorations, p. 225. See also Yeats, Letters, pp.

51 Yeats, Ietters, p. 525.

52 Rajan, "Yeats and the Renaissance," p. 114 .

53 Ben Jonson, The New Inn in Ben Jonson, Vol. VI, Herford and Simpson, eds., p. 492 .

54 W. B. Yeats, The Autobiography of William Butler Yeats (New York: Collier, 1974), Pp. 217-18.

55 Ben Jonson, Discoveries in Ben Jonson, Vol. VIII, Herford and Simpson, eds., p. 637 .

56 See Nichols, The Poetry of Ben Jonson, pp. 161-2. Furthermore, Nichols says that Jonson is probably remembering Horece, Odes, IV, 3 (Loeb edition, p. 292), which translates: "O you who, if you wanted, could also give the voice of a swan to dumb fishes..." Nichols adds that "It is possible that Yeats also drew directly from Borace."

57 Pritchard, "The Uses of Yeats's Pootry," p. 357.

58 George Hoore, Fail and Farewell: A Prilosy, Vol. III, Vale (Iondon: William Hoinemann, 1914), pp. 160-1. Also quoted but inoorrectly cited as Ave, the first volume of the trilogy, by A. Norman Jeffares, H. B. Teats: Man and Poet (1949, Ipt. Iondon: Routledge \& Kegan Paul, Itd., 1966), p. 179. Cf. Joseph Hone, W. B. Yeats, 18651939 (New York: St. Martin's Press, 1962), pp. 292-3.

59 W. B. Yeats, The Variorum Edition of the Plays of $W . B_{\text {. }}$ Yeats, Russell K. Alspach, od. (New Yorks Macmillan Publishing Co., Inc., 1966), p. 1170.

60 W. B. Yeats, Memoirs, Autobiography-Firgt Draft \& Jourmal, transcribed and od. by Denis Donoghue (Few Yorks Macmillan Publishing Co., Inc., 1972), p. 270.

61

Ib1d. 
62

The five poems are, "The Realists," "The Mountain Tomb," "To a Child Dancing in the Wind," "A Memory of Youth" and "Fallen Majesty," all in Responsibilities. See K. G. Goodrin, "Some Corrections to Standard Blographies of Yeats," Notes and Queries, Vol. 12, No. 7 (July, 1965), pp. 260-2.

63 W. B. Yeats, as reported in the Manchester Guardian, 15 July 1913, p. 10, and included in "Some New Letters from W. B. Yeats to Lady Gregory," Donald T. Torohiana and Glenn O'Malley, eds., A Review of English Literature, Vol. IV, No. 3 (July, 1963), p. 35.

64 Torohiana and O'Malley, eds., "Some New Letters from W. B. Yeats to Lady Gregory," p. $34 n$.

65 Hone, W. B. Yeats, 1865-1939, p. 294.

66 Moore, Vale, p. 161.

67 Yeats, Memoirs, p. 271.

68 Quoted by Hone, H. B. Yeats, 1865-1939, p. 294.

69 Rupin W. Desal, Yeats's Shakespeare (Evanston: Northweatern Univ. Press, 1971), p. 41.

70 Saul, Prolegomena to the Study of Yeats's Poems, p. 101.

71 w. B. Yeats, MYthologies (New York: Collier Books, 1974), p. 360 .

72 W. B. Yeats, The Variorum Edition of the Poems of W. B. Yeats, Peter Allt and Russell K. Alspach, eds. (New York: Macmilian Publishing Co., Inc., 1971), p. 321.

73 Ben Jonson, Under-wood in Ben Jonson, Vol. VIII, Herford and Simpson, eds., p. 175.

74 Ben Jonson, The Poetaster in Ben Jonson, Vol. IV, Herford and Simpson, eds., p. 324 .

75 Thomas R. Whitaker, Swan and Shadow: Yeats's Dialogue with History (Chapel Hills Univ. of North Carolina Press, 1964), p. 158.

76 Saul, Prolegomena to the Study of Yeats's Poems, p. 101. 
77 Nichols, The Poetry of Ben Jonson, p. 156; also see p. 161.

78 Harold Bloom, Yeats (New Yorks Oxford Univ. Press, 1970), p. 176 .

79 McAlindon, "Yeats and the English Renaissance," p. 165.

80 Donald Davie, "Michael Robartes and the Dancer, " An Honoured Guest, Denis Donoghue and J. R. Mulryne, eds. (Londons Edward Arnold, Ltd., 1965), pp. 82-4; and "Yeats, The Mester of a Trade," H. B. Yeats: A Critical Anthology, William H. Pritchard, ed. (Middlesex, Eng. 8 Penguin, 1972), pp. 304-5.

81

Bloom, Yeats, p. 176.

82 Yeats, The Autobiography, pp. 217-18.

83 Bloom, Yeats, p. 173.

84 Henn, The Ionely Tower, pp. 122 and 124.

85 Bloom, Yeats, p. 176.

86 Ben Jonson, Vol. VIII, Herford and Simpson, eds., p. 237.

87 Ibid., pp. 214-15.

88 Bloom, Yeats, p. 177. Cf. Jeffares, W. B. Yeats, pp. 178-9.

89 Moore, Vale, P. 162 , ibid.

90 Nichols, The Poetry of Ben Jonson, P. 162.

91 Wright, The Poet in the Poem, p. 107.

92 Ibid., p. 108.

93 Rajen, "Yeats and the Renaissance," p. 114.

94 Frank Kermode, The Romantic Image (New York: Macmillan Publishing Co., Inc., 1957), pp. 38-40.

95 Ibid., pp. 39-40. 
96 Ibid., p. 40.

97 McAlindon, "Yeats and the English Renaissance," p. 169.

98 Ibid.

99 Ibid., p. 168.

100 Ibid.

101 Synge quoted by Yeats, The Autoblography, P. 345; similar version also found in Yeats, Essays and Introductions, p. 308.

102 Kermode, The Romantio Image, p. 40.

103 Ibid.

104 Ibid., pp. 40-1, 42.

105 Beryl Rowland, "The Other Father in Yeats's 'A Prayer for 14y Daughter, " Oxbis Litterarum (Copenhagen), Vol. XXVI, No. 4 (1971), pp. 284-90.

106 Marjorie Perloff, "Yeats and the Occasional Poems 'Easter 1916," Papers on Language and Literature, Vol. IV, No. 3 (Summer, 1968), p. 309 .

107 Davie, "Yeats, The Vaster of a Trade," p. 306.

108 Davie, "'Michael Robartes and the Dancer," p. 82.

109 Nichols, The Poetry of Ben Jonson, pp. 87-8.

110 Davie, "'Miohael Robartes and the Dancer," p. 84.

111 Nichols, The Poetry of Ben Jonson, p. 161.

112 MoAlindon, "Yeats and the English Renaissance," p. 168.

113 These examples are indebted to MaAlindon's suggestions

(ibid., p. 167n). McAlindon cites further examples: Epigrammes, CIX, I3; Under-wood, XXX, 17-19; and Under-wood, IXV, 5-7. 
114 Charles Tomlinson, "Yeats and the Practioing Poet," An Honoured Guest, Donoghue and Mulryne, eds., p. 2.

115 George Brandon Saul, "In... Iruminous Wind," No. VII of the Dolmen Press Yeats Centenary Papers, Liam Miller, ed. (1965), p. 215.

116

Henn, The Ionely Torrer, p. 259.

127 Jon Stallworthy, Between the Lines; Yeats's Poetry in the Kaking (Iondons Oxford Univ. Press, 1963), p. 143.

118 J. R. Mulryne, "The 'Last Poems, " An Honoured Guest, Donoghue and Mulryne, eds., pp. 133-4.

119 Donoghue, William Butler Yeats, p. 143-4.

120 Mulryne, "The 'Last Poems, " p. 125-6.

121 Jon Stallworthy, Vision and Revision in Yeats's Last Poems (Oxford: Oxford Univ. Press, 1969), p. 37.

122

IbId.

123 Yeats, Explorations, pp. 418-20.

124 E. Engelberg, "Whe New Generation and the Acceptance of Yeats," K. B. Yeats, 1865-1939; Centenary Egagy on the Art of W. B. Yeats, D. E. S. Maxwell and S. B. Bushrui (Ibadan, Nigerias Ibadan Univ. Press, 1965), p. 100.

125 Davie, "Yeats, The Master of a Trade," pp. 305-6.

126 Robert Boum, The Poetic Art of William Butler Yeats (New York: Frederick Unger Publishing Co., 1969), pp. 1 and 3.

127

Davie, "Yeats, The Master of a Trade," p. 300.

128

Ibid., p. 303.

129

Ibid., p. 307.

130 Ibid., p. 308 . 
p. 328 .

131 Perlofe, "Yeats and the Ocoasional Poems 'Easter 1916,"

132 T. S. Eliot, "Tradition and the Individual Talent," The Sacred Wood (Iondon: Methuen \& Co., Itd., 1969), p. 49.

133 Yeats, Essays and Introductions, p. 253. 
REFERENCES CITED

Albright, Daniel. The Myth Againat Kyth: A Study of Yeats's Imagination in Old Age. Iondon: Oxford Univ. Press, 1972.

Alspach, Russell K. "Yeats's First Two Published Poems." Yodern Language Notes, Vol. IVIII, No. 7 (Nov., 1943), Pp. 555-7.

Altieri, Charles. "From a Comio to a Tragic Sonse of Language in Yeats's Mature Poetry." Moderm Language Quarterly, Vol. 33, No. 2 (June, 1972), pp. 156-171.

Barish, Jonas A. Ben Jonson and the Language of Prose Comedy. Cambridge, Mass.: Harvard Univ. Press, 1967.

Ben Jonson, Vols. I-XI. C. H. Herford, Percy and Evelyn Simpson, eds. Oxford: At the Clarendon Press, 1954.

Beum, Robert. The Poetic Art of William Butler Yeats. New York: Frederick Unger Publishing Co., 1969.

Bloom, Harold. Yeats. New York: Oxford Univ. Press, 1970.

Boccaccio, Glovanni. Boocacoio on Poetry: Being the Preface and the Fourteenth and Fifteenth Books of Boccaccio's Genealogia Deorum Gentilium. An English version with Introduction and commentary by Charles G. Osgood. New York: The Iiberal Arts Press, Inc., 1956.

Bourgeois, Maurice. John Millington Synge and the Irigh Theatre. New Yorks Benjamin Blom Ince, $1913 ;$ reissued 1965.

Bradbrook, Muriel C. "Yeats and Elizabethan Iove Poetry." The Dublin Magazine, Vol. 4, No. 2 (Summer, 1965), pp. 40-55.

Bushrui, S. B. "The King's Threshold', A Defense of Poetry." A Revier of English Literature, Vol. IV, No. 3 (July, 1963), pp. 81-94.

- Yeats's Verse-Plays; The Revlsions, 1900-1910. Iondons Oxford Univ. Pres8, 1965.

Carpenter, William M. "The Green Helmet Poems and Yeats's Nyth of the Renaissance." Modern Philology, Vol. 67, No. I (Aug., 1969), pp. 50-59.

Davie, Donald. "Michael Robartes and the Dancer." An Honoured 
Guest. Denis Donoghue and J. R. Mulryne, eds. Iondon z Edward Arnold, Itd., 1965.

- "Yeats, The Master of a Trade." W. B. Yeatar A Critioal Antholosy. Nilliam H. Pritchard, ed. Middlesex, Eng.: Penguin, 1972.

Desai, Rupin K. Yeats's Shakeapeare. Evanston: Northwesterm Univ. Pres8, 1971.

Donoghue, Denis. William Butler Yeats. New York: The Viking Press, 1971.

Duncan, Douglas. "Synge and Jonson (with a parenthesis on Ronsard)." Sunshine and the Moon's Delight: A Centenary Tribute to John Millington Synge. S. B. Bushrui, ed. New York: Barmes \& Noble Publishera, 1972. Pp. 205-18.

Eddins, Dwight. Yeats: The Nineteenth Century Matriz. University, Ala.: Univ. of Alabama Press, 1974.

Eliot, T. S. "Ben Jonson." Ben Jonson: A Collection of Critical Essays. Jonas A. Barish, ed. Englowood Cliffs, N.J.: PrenticeHall, Inc., 1963. Pp. 14-23.

- "Tradition and the Individual Talent." The Sacred Wood. Iondon: Methuen \& Co., Itd., 1969.

Ellig-Fermor, Una. The Irish Dramatic Hovement. Iondon: Methuen \& Co., Itd., 1954 .

Ellmann, Richard. Yeats: The Man and the Masks. New Yorks E. P. Dutton \& Co., Ino., 1948.

Enck, John J. Jonson and the Comio Mruth. Madison, Wis.: Univ. of Wisconsin Pres8, 1959.

Engelberg, E. "The New Generation and the Acceptance of Yeats." W. B. Yeats, 1865-1965: Centenary Essays on the Art of $H_{\text {. }}$ B. Yeats. D. E. S. Maxwell and S. B. Bushrui, eds. Ibadan, Niger1a: Ibadan Univ. Press, 1965. Pp. 88-101.

Bvans, B. Ifor. Tradition and Romanticiam, Studies in English Poetry from Chaucer to W. B. Yeats. Hamden, Conn.: Archon Books, 1964.

Goodwin, K. G. "Some Correotions to Standard Biographies of Yeats." Notes and Queries, Vol. 12, No. 7 (July, 1965), pp. 260-2.

Goodwin, K. I. The Influence of Ezre Pound. Iondons Oxford Univ. Press, 1966.

Gurd, Patty. The Early Poetry of Villiam Butler Yeats. Iancaster, 
Pa.: New Era Printing Co., 1916.

Harper, George Mills. "Yeats's Quest for Eden." No. IX of the Dolmen Press Yeats Centenary Papers (1965).

Henn, T. R. "The Green Helmet' and 'Responsibilities." An Honoured Guest. Denis Donoghue and J. R. Mulryne, eds. Londons Edward Arnold, Itd., 1965.

- The Lonely Tower; Studies in the Poetry of W. B. Yeats.

New Yorks Pellegrini \& Cudahy, 1952.

- "The Rhetoric of Yeats." In Exoited Reverie. A. Norman Jeffares and K. G. W. Cross, eds. New Yorks Macmillan PublishIng Co., Inc., 1965. Pp. 102-22.

Hone, Joseph. W. B. Yeats, 1865-1939. New Yorks St. Martin's Press, 1962.

Jamieson, Michael. "Introduotion." Ben Jonson, Three Comedies. Michael Jamieson, ed. Harmondsworth, Eng. 8 Penguin Books, 1974. Pp. 7-3l.

Jeffares, A. Norman. "Introduction." Eleven Plays of William Butler Yeats. A. Norman Jeffares, od. Now York: Collier Book日, 1971. Pp. 1-14.

- H. B. Yeats: Man and Poet. London: Routledge \& Kegan Paul, Itd., 1966.

and A. S. Knowlend. A Commentary on the Collected Plays of W. B. Yeats. Stanfords Stanford Univ. Press, 1975.

Joyce, James. Portrait of the Artist as a Young Man. New Yorks Viking Press, 1970.

Kermode, Frank. The Romantic Image. New Yorks Macmillan Publishing Co., Inc., 1957 .

Kilroy, James, comp. The "Playboy" Riots. Dublins Dolmen Press, 1971.

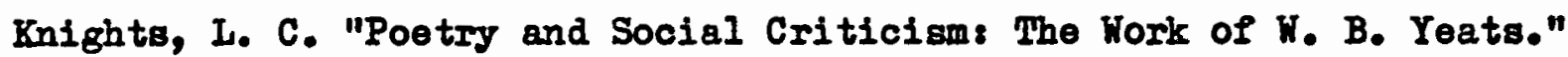
Explorations: Essays in Critioism Mainly on the Literature of the Seventeenth Century. New Yorks University Press, 1964. Chapter Ten. Pp. 190-205.

MoAlindon, T. "Yeats and the English Renaissance." PMLA, IXXXII (May, 1967), pp. 157-69.

Mecneice, Louis. The Poetry of H. B. Yeats. London \& New Yorks Oxford Unir. Press, 1941. 
Meir, Colin. The Ballads and Songs of W. B. Yeats, The Anglo-Irish Heritage in Subject and Style. New York: Barmes and Noble, 1974.

Menon, V. K. Narayana. The Development of William Butler Yeats. London: Bradford \& Dickens, 1960.

Moore, George. Hail and Farevell, A Trilogr, Vol, III, Vale. Iondon: villiam Heineman, 1914.

Moore, John Rees. Masks of Love and Deaths Yeats as Dramatist. Ithaca and London Comell Univ. Press, 1971.

Mulryne, J. R. "The "Last Poems." An Honoured Guest. Denis Donoghue and J. R. Mulryme, eds. Iondons Edward Amold, Itd., 1965.

Nelick, Frank C. "Yeats, Bullen, and the Irish Drama." Modern Drama, I (1958), pp. 196-202.

Nichols, J. G. The Poetry of Ben Jonson. Ner Yorks Barnes \& Noble, Inc., 1969.

Orgel, Stephen. "Introduction." Ben Jonsone Selected Magques. Stephan Oxgel, ed. New Haven: Yale Univ. Press, 1970. Pp. 1-39.

Partridge, Edward B. The Broken Compass: A Study of the Major Comedies of Ben Jonson. New Yorks Columbia Univ. Press, 1958.

Perloff, Marjorie. "Yeats and the Occesional Poems "Eester 1916." Papers on Language and Literature, Vol. IV, No. 3 (Summer, 1968), pp. 308-28.

Pollook, J. H. William Butler Yeats. Dublin: The Talbot Press, Itd., 1935.

Price, Alan. Synge and Anglo-Irish Drama. New York: Russell \& Russol1, 1972.

Pritchard, William H. "The Uses of Yeats's Poetry." W. B. Yeatsi A Critical Anthology. William H. Pritchard,ed. Middlesex, Eng.8 Penguin Books, 1972. Pp. 350-69.

Rajen, B. "Yeats and the Renaissance." Mosaic, Vol. 5, No. 4 (Summer, 1972), pp. 109-18.

Rowlend, Beryl. "The Other Father in Yeata's 'A Prayer for My Daughter." Orbis Litterarum (Copenhegen), Vol. XXVI, No. 4 (1974), pp. 284-90.

Saul, George Brandon. "In...Luminous Kind." No. VII of the Dolmen Press Yeats Centenary Papers. Ilam Miller, ed. (1965). Pp. 197-256. 
- Prolegomena to the Study of Yeats's Poems. Philadelphias

Univ. of Pennsylvania Press, 1957.

Sena, Vinod. "Yeats on the Possibility of an English Poetic Drama." Modern Drame, Vol. IX, No. 2 (Sept., 1966), pp. 195-205.

Sidney, Philip. An Apology for Poetry; or, The Defense of Poesy. Geoffrey shepherd, ed. Londons Thomas Nelson and Sons, Itd., 1965.

Stallworthy, Jon. Between the Lines; Yeats's Poetry in the Making. London: Oxford Univ. Press, 1963.

- Vision and Revision in Yeats's Last Poems. Oxford: Oxford Univ. Press, 1969.

Stock, Noel. The Ilfe of Erra Pound. New York: Avon Books, 1974.

Swinburne, Algermon C. A Study of Ben Jonson. Iondon: Chatto \& Winddus, 1889.

Symonds, John A. Ben Jonson. London: Longmans, Green, and Co., 1888.

Synge, J. M. J. M. Synge's Plays, Poems and Prose. Intro. Michael Mac Liammoir. 1941; rpt. London: Everyman'B Iibrary, 1964.

Telfer, Giles W. I. "Yeats's Idea of the Gael." No. IV of the Dolmen Press Yeats Centenary Papers. Ilem Miller, ed. (1965).

Tindall, William York. "W. B. Yeats." Columbia Esgays on Moderm Writers. New York and Iondon: Columbia Univ. Press, 1966.

Tomlinson, Charles. "Yeats and the Practicing Poet." An Honoured Guest. Denis Donoghue and J. R. Mulryne eds. Iondons Edward Arnold, Ltd., 1965.

Untereoker, John E. A Reader's Guide to W1lliam Butler Yeats. New York: Noonday Press, 1954.

Ure, Peter. "The Plays." An Honoured Guest. Denis Donoghue and J. R. Nulryne, eds. Iondon: Edward Arnold, Ltd., 1965.

- Towards a Mythologys Studies in the Poetry of W. B. Yeats. New York: Russell \& Russell, 1967.

- W. B. Yeats and the Shakespearean Moment, On H. B. Yeats's Atti tude Towards Shakespeare as Revealed in his Criticism and In his Work for the Theatre. A Iecture delivered at Queen's University, Belfast, on 27 April 1966. Belfast Queen's University, Belfast (Institute of Irish Studies), 1969.

- Yeats and Anglo-Irish Literatures Critical Essays by Peter 
Ure. C. J. Rawson, ed. Liverpools Univ. of Liverpool, 1974. 1963.

- Yeats the Playwright. Iondonz Routledge \& Kegan Paul, Ltd.,

Whitaker, Thomas R. Swan and Shadow; Yeats's Dialogue with Hiatory. Chepel Hills Unive of North Caroline Press, 1964.

Wright, George T. The Poet in the Poem; The Personae of Eliot, Yeats, and Pound. Berkeley and Los Angeles: Univ. of California Press, 1960.

Yeats, W. B. The Autobiography of William Butler Yeats. New Yorks Macmillan Publishing Co., Inc., 1974.

- The Collected Pleys of W. B. Yeatg. New Yorks Macmillan Publishing Co., Inc., 1973.

- The Collected Poems of W. B. Yeats. New Yorks Maomillan Publishing Co., Inc., 1974. 1907 .

- "Discoveries: Second Series." Curtis Be Bradford, ed. The Nessachusetts Review, Vol. 5 (Winter, 1964), pp. 297-306.

- Essays and Introductions. New Yorks Collier Books, 1973.

- Explorations. New Yorks Collier Books, 1973.

- Letters of H. B. Yeats. Allan Wade, ed. New Yorks Macmillan Publishing Co., Inc., 1955.

- Memoirs; Autobiography-First Draft \& Jourmal. Transoribed and ed. by Denis Donoghue. New Yorkz Macmillan Publishing Co., Inc., 1973.

- Mythologies. New Yorks Collier Books, 1974.

- On the Boiler. Dublins Cuala Press, 1939.

- Plays and Controversies. Nerr Yorks Macmillan Publishing Co., Inc., 1924.

- "A Poetio Drama." Letters to the Now Island. Horace Regnolds, ed. Cambridge, Mass.: Harvard Univ. Press, 1976.

- "Some New Letters Prom ${ }$. B. Yeats to Lady Gregory." Donald T. Torchiana and Glenn O'Malley, ods. A Revieu of English Literature, Vol. IV, No. 3 (July, 1963), pp. 9-47. 
- "The Theatre of Beauty An Address Delivered before the Dramatic Club of Harvard Universi ty." Harper's Weekly, Vol. IV, No. 2864 (Nov. 11, 1911), P. 11.

- Uncollected Prose By H. B. Yeats, Vol. I. John P. Frayne, ed. New York: Columbia Univ. Press, 1970.

- Uncolleoted Prose By W. B. Yeata, Vol. II. John P. Frayno and Colton Johnson, eds. New York Columbia Univ. Press, 1976.

- The Variorum Edition of the Plays of W. B. Yeats. Russell K. Alspach, ed. New Yorks Macmilian Publishing Co., Inc., 1966.

- The Variorum Edition of the Poems of W. B. Yeats. Peter AIIt and Russell K. Alspach, eds. New Yorks Macmillan Publishing Co., Inc., 1971.

- A Vision. New Yorks Collier Books, 1973. 